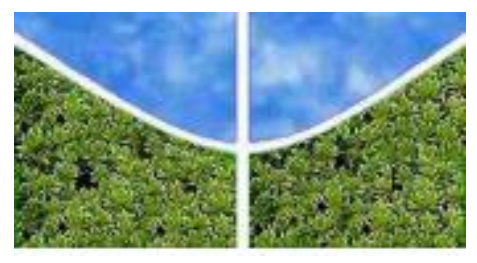

Universidade de Brasília

Instituto de Ciências Biológicas

Programa de Pós-Graduação em Zoologia

\title{
Áreas de Preservação Permanente como corredores ecológicos para a fauna de mamíferos de médio e grande porte no sul da Amazônia
}

Bárbara de Queiroz Carvalho Zimbres

Brasília - DF 2016 


\author{
Universidade de Brasília \\ Instituto de Ciências Biológicas \\ Programa de Pós-Graduação em Zoologia
}

\title{
Áreas de Preservação Permanente como corredores ecológicos para a fauna de mamíferos de médio e grande porte no sul da Amazônia
}

Tese apresentada ao Programa de Pós-Graduação em Zoologia da Universidade de Brasília como requisito parcial para obtenção do grau de Doutora em Zoologia

Orientador: Ricardo Bomfim Machado. D.Sc. Co-orientador: Carlos Peres, PhD

Brasília - DF 2016 


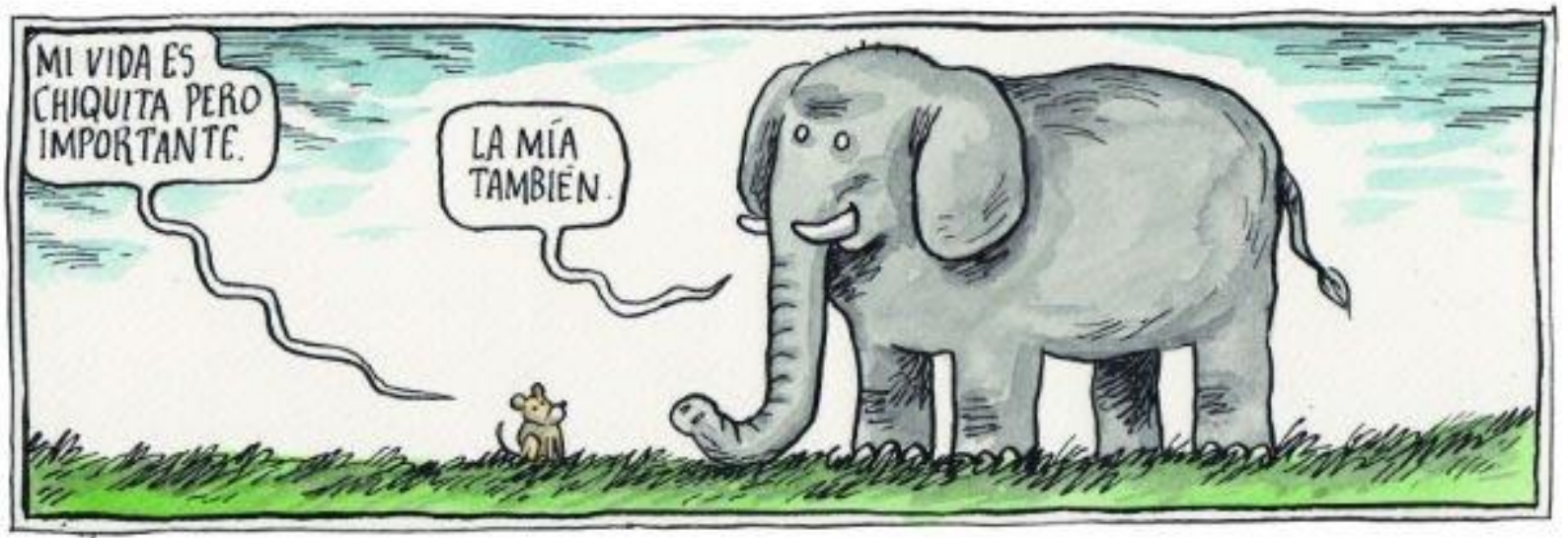

by Liniers 
Tese de doutorado

Bárbara de Queiroz Carvalho Zimbres

Título:

Áreas de Preservação Permanente como corredores ecológicos para a fauna de mamíferos de médio e grande porte no sul da Amazônia

Banca examinadora:

Prof. Dr. Ricardo Bomfim Machado

Presidente/Orientador

$\mathrm{ZOO} / \mathrm{UnB}$

Prof. Dr. Emerson Monteiro Vieira

Membro Titular

ECL / UnB

Prof. Dr. Jader Marinho-Filho

Membro Titular

$\mathrm{ZOO} / \mathrm{UnB}$
Profa. Dra. Mercedes Bustamante

Membro titular

$\mathrm{ECL} / \mathrm{UnB}$

Prof. Dr. Miguel Ângelo Marini

Membro Suplente

ZOO/UnB

Brasília, 9 de setembro de 2016 


\section{Agradecimentos}

Primeiramente, gostaria de agradecer à minha família por todo o apoio, e aos amigos que mais fizeram a diferença na hora do aperto, Ingrid de Mattos, Juliana Caldas, Marta Acácio e Vivian Ribeiro. Porque não é só de apoio técnico que depende um bom trabalho. Um agradecimento especial ao pessoal da tapera do lago pela amizade!

Gostaria também de agradecer ao meu orientador, Ricardo Machado, e co-orientador, Carlos Peres. Foi um prazer trabalhar com vocês e que venham as futuras colaborações!

A todos os meus colegas do laboratório de Planejamento Sistemático para a Conservação, pela parceria e companhia, e a todos os colegas “do andar de cima”, da Coleção de Mamíferos e do Laboratório de Ornitologia, pela amizade. Um agradecimento especial ao Pedro Dantas por todo o companheirismo, amor e apoio.

Agradeço muito ao Danilo Fortunato, à Luane Santos e à Vivian Ribeiro pela ajuda com parte das análises, sempre disponíveis para tirar dúvidas, e cuja ajuda fez uma diferença enorme na qualidade do trabalho.

Aos meus queridos ajudantes de campo, os "mateiros” Tatão, Alex e Seu Geraldo, por me ensinarem o que é conhecer a floresta na prática. À sempre companheira de aventuras Ana Martins, por dividir as responsabilidades e pelo apoio mútuo durante os dois anos de campo. Agradeço à Vivian Ribeiro e à Maria Lúcia Spanga pela ajuda no início do período de campo. E ao apoio logístico e amizade de Pedro Thomé e Lina Carvalho, sem os quais minha longa estada em Alta Floresta teria sido menos animada. Sou grata também aos estagiários ajudantes de campo, Kamilla Centurião, Camila Vilarinho, Davi Valdéz, Ben Robb e Tom Brown. E aos

queridos amigos ajudantes, que fizeram toda a diferença, Ísis Arantes, Thiago Filadelfo, Romina Cardozo e Pedro Dantas.

Agradeço a todos os proprietários das fazendas que autorizaram a realização do meu trabalho, principalmente ao Seu Romildo, Dona Ozana, Seu Nelson, família Pupin, Seu Antônio e o Seu Reginaldo, pelo interesse e cuidado com nossa equipe durante o trabalho. Agradeço à equipe do Cristalino Jungle Lodge e à família Da Riva por todo o apoio logístico.

Moram no meu coração todo o grupo de pesquisa do Prof. Carlos Peres, e todos os queridos amigos do Environmental School da Universidade de East Anglia. Em especial, 
agradeço a ajuda do Davi Teles, Rodrigo Begotti, Vanessa Richardson e Anderson Bueno por grandes e pequenas ajudas durante o processo!

Agradeço a toda a equipe do Programa de Pós-Graduação em Zoologia e sou muito grata aos membros da banca examinadora, por terem aceitado o convite e se disponibilizado a contribuir com o trabalho.

Por último, agradeço às agencias financiadoras deste projeto, CAPES pelas bolsas de doutorado no Brasil e na Inglaterra, Rufford Small Grants Foundation, National Geographic Society e IdeaWild pelo financiamento de campo, e FAPDF por me permitir ir à ATBC apresentar parte dos resultados deste trabalho. 


\section{Sumário}

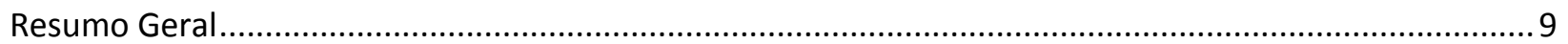

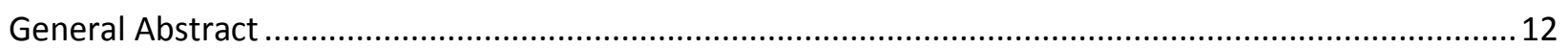

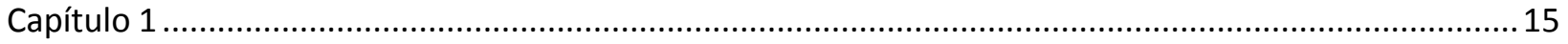

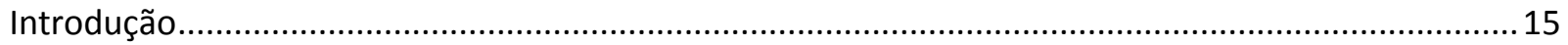

Conceitos de corredores ecológicos e suas aplicações no Brasil.......................................................18

Áreas de Preservação Permanente (APPs) como corredores ecológicos ............................................21

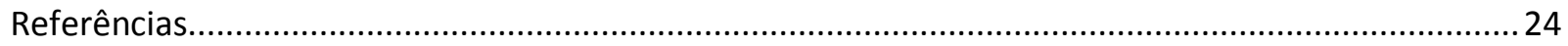

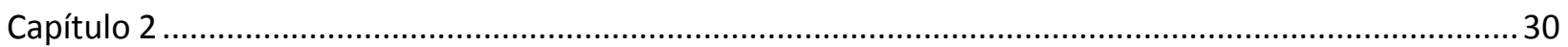

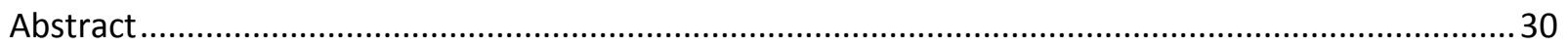

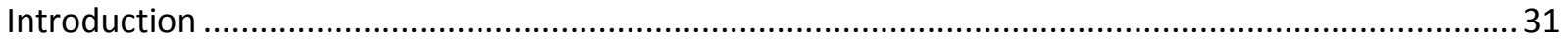

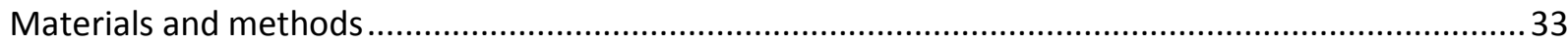

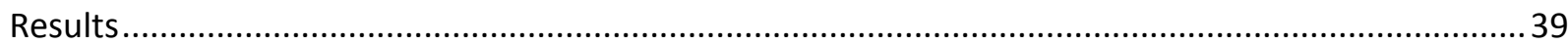

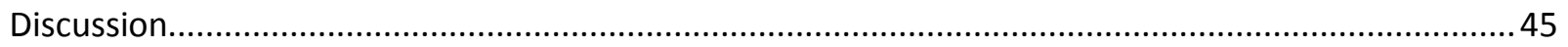

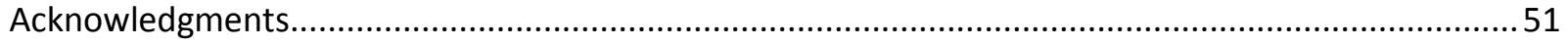

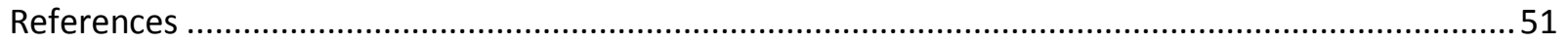

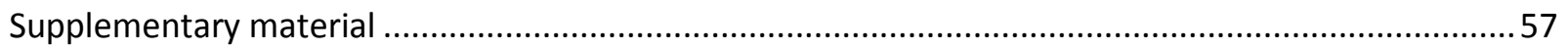

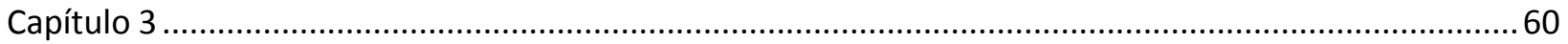

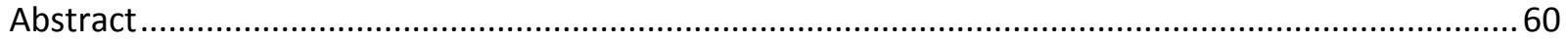

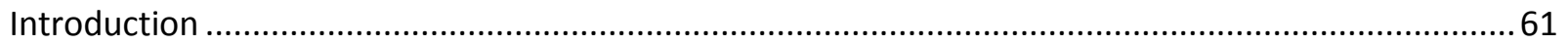

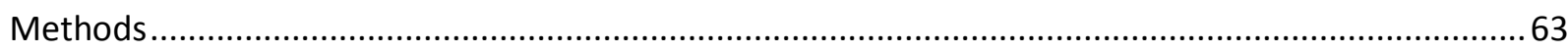

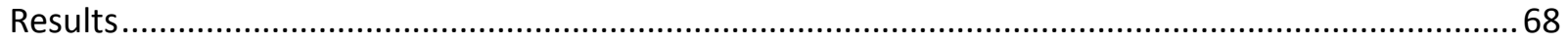

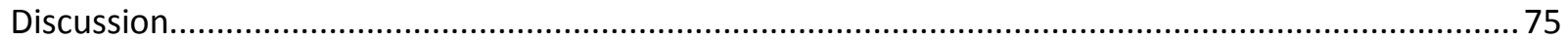

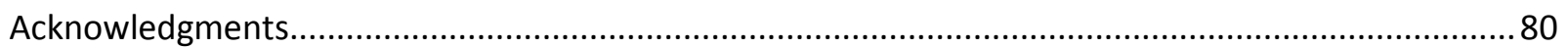

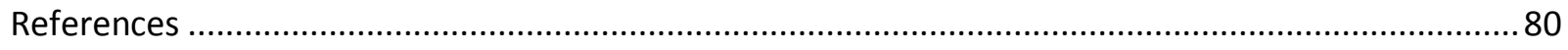

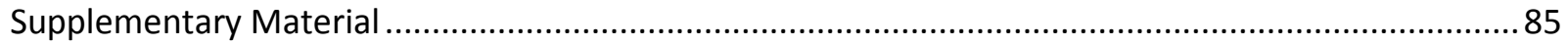

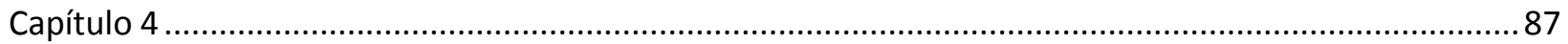

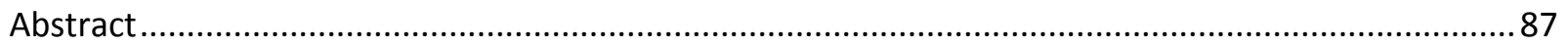

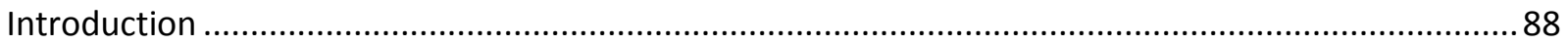

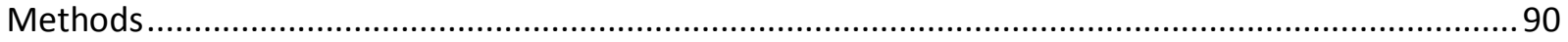

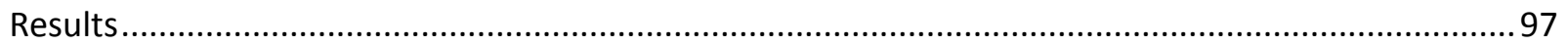

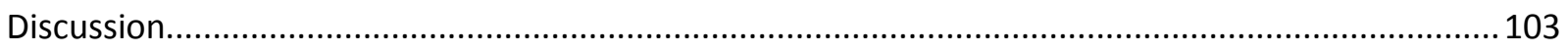




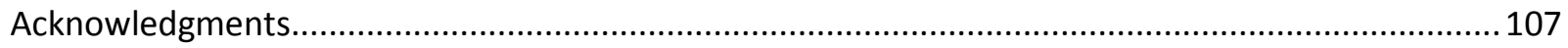

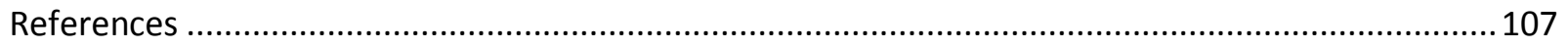

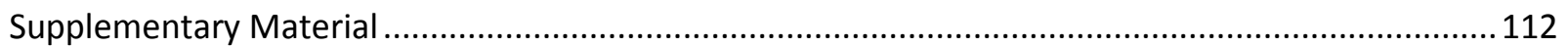

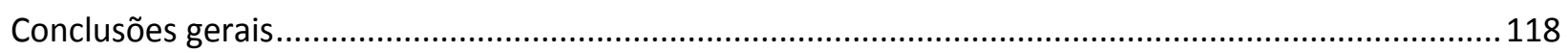




\section{Resumo Geral}

A conectividade de uma paisagem é um dos fatores determinantes da viabilidade de populações animais, frente aos efeitos da perda e fragmentação do hábitat. Os corredores ecológicos são uma das estratégias defendidas para se manter a conectividade de uma paisagem fragmentada. No Brasil, a manutenção de áreas de preservação permanente (APP) ao longo de cursos d'água, é prevista com o objetivo primário de preservar os recursos hídricos, mas as mesmas apresentam o potencial de funcionar como um elemento de conexão ubíquo em toda a paisagem. Nesta visão, elas funcionariam como corredores ecológicos. No entanto, é necessário compreender quais fatores estão envolvidos na utilização efetiva desses conectores pela fauna, incluindo aspectos como a largura, qualidade, configuração na paisagem, entre outros. Essas discussões são cruciais no momento em que temos que lidar com os possíveis efeitos negativos causados pelas alterações do Código Florestal Brasileiro, que afetam a necessidade de recomposição de um enorme passivo ambiental em APPs no país. Nesse contexto, a presente tese avaliou o papel das APPs como componentes espaciais que promovem a conectividade de paisagens fragmentadas do ponto de vista da fauna, especificamente de mamíferos terrestres de médio e grande porte. A tese está dividida em quatro capítulos, sendo o primeiro referente a uma revisão que introduz os conceitos e objetivos da manutenção de corredores ecológicos, tanto de acordo com a literatura ecológica quanto com a legislação brasileira. Os três capítulos seguintes fazem parte do trabalho empírico realizado em uma paisagem fragmentada no sul da Amazônia, e estão apresentados no formato de manuscritos científicos, em inglês.

O primeiro capítulo revisa os conceitos sobre corredores ecológicos encontrados na teoria e aplicados na prática no Brasil, tanto em escalas locais quanto regionais. Também discute as vantagens e desvantagens de se investir em corredores como estratégia de manejo, de acordo com o que defensores e críticos apresentam na literatura. Finalmente, é discutido o potencial das APPs como elementos conectores em paisagens fragmentadas no Brasil e como as mudanças recentes (2012) no Código Florestal Brasileiro podem afetar esses elementos.

O segundo capítulo apresenta um estudo empírico, em que se avaliou o uso dos corredores ecológicos em uma paisagem fragmentada no sul da Amazônia pela comunidade de mamíferos. Nesse sentido, foi avaliado como varia a riqueza, a composição e a diversidade funcional da comunidade nos fragmentos lineares nas APPs. Foram selecionadas 43 áreas 
riparias para o estudo, sendo 38 corredores ripários em APPs e cinco áreas pseudo-controles, em áreas de floresta contínua, em uma paisagem que compreendia três municípios no norte do estado do Mato Grosso (Alta Floresta, Carlinda e Paranaíta). Foram instaladas entre quatro e cinco armadilhas fotográficas em cada área selecionada para amostrar a fauna de mamíferos durante as estações secas de 2013 e 2014. A riqueza, composição e diversidade funcional foram comparadas entre as APPs e as áreas ripárias contínuas. Os resultados indicam que todas essas medidas foram maiores nas áreas controle do que em áreas ripárias desmatadas. Os padrões da comunidade nos corredores ripários de acordo com a largura, a qualidade estrutural, a 40 configuração da paisagem também foram avaliados. A degradação da qualidade das florestas esteve associada a uma menor riqueza geral, enquanto a riqueza e diversidade funcional de espécies estritamente florestais foram maiores em corredores mais largos. A composição da comunidade indicou que a perda e degradação dos corredores ripários favorecem espécies tolerantes à matriz antrópica, composta basicamente por pastagens. A conclusão do estudo é que as APPs ripárias têm o potencial de funcionar como conectores na paisagem, mas que largura e degradação florestal são fatores chave na determinação do sucesso desses conectores.

O terceiro capítulo consiste também na avaliação do papel das APPs como corredores ecológicos, mas com enfoque nos padrões de ocupação de cada espécie de mamífero. Com os mesmos dados obtidos com a amostragem apresentada no capítulo 2, modelos de ocupação que levam em consideração diferenças na detectabilidade foram feitos para 10 espécies: a capivara (Hydrochaeris hydrochoerus), a paca (Cuniculus paca), a cotia (Dasyprocta leporina), o saruê (Didelphis marsupialis), o tatu-galinha (Dasypus novemcinctus), a anta (Tapirus terrestris), o queixada (Tayassu pecari), o cateto (Pecari tajacu), o quati (Nasua nasua) e a irara (Eira barbara). Esses modelos também foram utilizados para testar o efeito da largura, da qualidade e

55 do contexto dos corredores ripários avaliados como fatores explanatórios das variações encontradas. Finalmente, os padrões obtidos foram extrapolados para as 1.915 demais matas ripárias identificadas nos três municípios e, desta forma, foi possível identificar as APPs com maior e menor potencial de manter as diferentes espécies na região. A ocupação de oito espécies respondeu aos fatores testados, e a degradação florestal foi novamente uma das variáveis mais

60 importantes para explicar a probabilidade de ocupação de seis espécies. Na paisagem como um todo, as matas ripárias que apresentaram um menor potencial de manter as espécies foram aquelas com baixa com qualidade florestal e este aspecto foi mais importante do que a estrutura 
de paisagem. Tais áreas, ou seja, APPs mais degradadas e com menor potencial de promover conectividade, estão localizadas no norte do município de Alta Floresta e em Carlinda, regiões com ocupação mais antiga.

O quarto capítulo apresenta uma avaliação dos determinantes de perda e degradação de APPs ripárias, tanto ao longo de cursos d’água quanto de nascentes. Essa análise foi realizada somente no município de Alta Floresta, para onde havia um mapa disponível da rede hidrográfica completa (rios e nascentes) e de mais de 3.000 propriedades privadas delimitadas.

70 Foi examinado como determinantes espaciais (distância da cidade, distância de estradas e o tamanho da propriedade) influenciam a área mantida e a qualidade da floresta nessas APPs. Ademais, os padrões observados foram relacionados à obediência à legislação, de acordo com o antigo (Lei 4771/65) e o novo Código Florestal (Lei 12.651/12). Os padrões de alteração que ocorrem no interior das matas ripárias em resposta à degradação florestal também foram descritos e explorados em uma escala mais local, com os dados empíricos coletados durante o estudo descrito nos capítulos 2 e 3 . A perda de habitat e a degradação florestal estão comumente associadas, mas ambos os aspectos podem responder de modo independente aos mesmos determinantes. Florestas ao redor de nascentes estavam em pior estado do que florestas ao longo de cursos d'água, e ambos pequenos e grandes proprietários tenderam a remover áreas de nascente mais do que o permitido legalmente. A proximidade de estradas também influenciou negativamente a qualidade e quantidade de floresta remanescente nos dois casos, e a distância de cidades afetou todas as variáveis testadas exceto qualidade de mata de nascente. A degradação foi maior em florestas ripárias mais estreitas, e as mudanças estruturais detectadas no interior das matas inclui a intrusão de gado, que afeta a densidade de sub-bosque, e a diminuição da altura e homogeneidade do perfil da floresta.

Palavras-chave: corredores ecológicos, conectividade, degradação florestal, ecologia de paisagem, matas ripárias. 


\section{General Abstract}

Landscape connectivity is one of the determinants of animal population viability in the face of habitat loss and fragmentation, and ecological corridors are one of the strategies used to safeguard the connectivity of a fragmented landscape. In Brazil, the maintenance of riparian forest buffers (Permanent Protection Areas, APP) along streams and rivers is prescribed by the environmental legislation with the primary goal of preserving the health of the hydrological systems, but they also have the potential of serving as a landscape connector, functioning as ecological corridors. It is however necessary to understand which factors influence the effective use of these connectors by the local fauna, such as corridor width, quality, configuration of the surrounding landscape, among others. This discussion is far from trivial, since we currently have to deal with the possible deleterious effects of the newly approved changes in the Brazilian

105 Forest Code, which affect the restoration requirements in APPs across the country. In this context, the current work aimed at assessing the role of these APPs in promoting landscape connectivity for the native fauna, specifically the medium- and large-bodied terrestrial mammals. The thesis is divided into four chapters. The first is a review of the theme, which introduces the concepts and general goals of ecological corridors, both according to the scientific literature as well as to the Brazilian legislation. The following three chapters comprise the empirical work conducted in a highly fragmented landscape in the southern Amazon, and are presented in the form of scientific manuscripts, in English.

The first chapter revises the concepts of ecological corridors found in the literature and applied in practice in Brazil, both at local and regional scales. It also presents the arguments pro and against corridors as a management strategy, according to proposers and critics of ecological corridors. Finally, we discuss the potential of APPs to act as landscape connectors in Brazil, and how the recent changes (2012) in the Brazilian Forest Code may affect this potential.

The second chapter presents an empirical study, in which we assessed the use of ecological corridors by the community of terrestrial mammals in a fragmented landscape in southern Amazonia. We tested how community richness, composition, and functional diversity vary within linear riparian APP patches. We selected 43 riparian areas for the study, 38 of which were riparian remnants, and 5 were pseudo-control riparian areas embedded in continuous forest. The study landscape spanned three municipalities in the North of the state of Mato Grosso (Alta Floresta, Carlinda, and Paranaíta). From four to five camera traps were installed within each area 
125 selected to sample the mammal community during the dry seasons of 2013 and 2014. Community richness, composition, and functional diversity were compared between APPs and continuous riparian areas. Results indicated that all these response variables were higher in control areas. Community patterns within riparian remnants were also assessed according to corridor width, structural quality, and landscape configuration. Forest quality erosion was associated to a general lower richness, while the richness and functional diversity of forest specialist species were higher in larger corridors. Community composition shifts indicated that loss and degradation of riparian corridors favour matrix-tolerant species. This study concludes that riparian APPs have the potential of acting as landscape connectors, but that corridor width and degradation are key factors in determining the success of these elements as a management 135 strategy.

The third chapter also evaluates the role of the APPs as ecological corridors, but focuses on occupancy patterns of each analysed mammal species. With the same empirical data presented in Chapter 2, occupancy models, which take into consideration differences in detection probability, were built for ten species: the capybara (Hydrochaeris hydrochoerus), the lowland paca (Cuniculus paca), the red-rumped agouti (Dasyprocta leporina), the posssum (Didelphis marsupialis), the nine-banded armadillo (Dasypus novemcinctus), the tapir (Tapirus terrestris), the white-lipped peccary (Tayassu pecari), the collared peccary (Pecari tajacu), the coati (Nasua nasua) and the tayra (Eira barbara). These models were also used to test the effect of width, quality and landscape context of the sampled riparian remnants as explanatory variables. Finally, 145 the observed patterns were extrapolated to 1915 remaining riparian forests, manually identified in the three municipal counties. We were therefore able to identify the APPs with the highest and lowest potential for maintaining the different species in the region. The occupancy probabilities of eight species responded to either one or more of the factors tested, and forest degradation was again the most important variable, explaining occupancy patterns of six species. In the landscape as a whole, the riparian patches that presented a lower potential for harbouring the species were those with low internal quality, and this factor was more important than landscape structure. These more highly degraded areas, with lower potential to promote landscape connectivity, were located in the North of the municipal county of Alta Floresta and in Carlinda, portions of the landscape with an earlier history of human occupation. 
The fourth and last chapter presents an evaluating of the driver of riparian APP loss and degradation, both along streams and around headwaters. This analysis was conducted for the Alta Floresta municipal county only, for which we had a map of the complete hydrological network and the headwaters sites, as well as a map of over 3000 private landholdings. We examined how spatial drivers (distance to town, distance to roads, and landholding size) affect 160 the amount of forest set-asides and the quality of the forest in these APPs. Moreover, the observed patterns were associated to legislative compliance, according to both the previous (Bill 4771/65) and the new Forest Code (Bill 12.651/12). Environmental changes that occur within riparian forests associated to forest degradation were also explored at a more local scale, using the empirical data we obtained during the field study described in Chapters 2 and 3. Habitat loss

165 and degradation are commonly associated, but they may also respond independently to the same drivers. Forest remnants around headwaters were generally worse off than remnants along streams, and both small and large landholders removed headwater forests more than legally permitted. Proximity to roads also negatively influenced the quality and amount of remnants forest in both cases, while distance to town affected all but one variable - headwater forest 170 quality. Forest degradation was higher in narrower riparian forests, and structural changes detected within the remnants included: cattle intrusion, which affects understory density, and forest profile height and homogeneity.

Keywords: ecological corridors, connectivity, forest degradation, landscape ecology, riparian 175 forests. 


\section{Capítulo 1}

Conservação da fauna em paisagens fragmentadas: uma revisão sobre áreas de preservação permanente como corredores ecológicos no Brasil

Introdução

A perda e fragmentação de hábitat causam, entre suas principais consequências, a fragmentação das populações animais anteriormente contínuas. O corpo teórico que discute as implicações desse processo inclui a teoria de metapopulações (Hanski, 1998), que compartilha com a teoria de biogeografia de ilhas (MacArthur \& Wilson, 1967) a noção de que as taxas de imigração e extinção em manchas (ou originalmente, ilhas) irão definir a probabilidade de permanência das populações (ou originalmente, comunidades). Nesse contexto, conclui-se que um dos fatores envolvidos na viabilidade de uma população fragmentada é a conectividade dos elementos de uma paisagem, que define a taxa de troca de indivíduos entre as sub-populações (Noss 1987; Haddad \& Tewksbury 2006). O que representa conectividade, no entanto, depende do ponto de vista dos organismos em questão, e isso complica o estudo da conectividade como estratégia de manejo para um grupo abrangente de animais. Observa-se uma grande idiossincrasia nos padrões observados com relação às respostas de cada grupo ao processo de fragmentação, à estrutura das paisagens e às estratégias de manejo (Harrison 1992).

No centro dessa discussão, como uma das estratégias mais defendidas de se manter a conectividade de uma paisagem, estão os corredores ecológicos. A partir principalmente da década de 1980, as controvérsias relacionadas aos corredores tomaram espaço na literatura ecológica, com grupos defendendo o potencial desses elementos como mitigação do isolamento das populações ameaçadas pela fragmentação, e outros chamando atenção para a incerteza da eficácia e para os possíveis custos dessa estratégia (Noss 1987; Simberloff \& Cox 1987; Saunders et al. 1991; Hobbs 1992). O principal mecanismo envolvido na importância dos corredores ecológicos consistiria no "efeito resgate" (Brown \& Kodric-Brown 1977), em que indivíduos migrantes atingem áreas anteriormente isoladas, revertendo os eventos de extinção da população residente (Gonzalez et al. 1998), protegendo as sub-populações de depressões endogâmicas (Noss 1987) e, preservando processos ecológicos (Bennet 1999). 
Por outro lado, discutiu-se que corredores ecológicos poderiam aumentar o risco de invasão de espécies exóticas, de dispersão de doenças, a susceptibilidade das manchas a perturbações (e.g. o fogo), e aumentar de forma a taxa de imigração em manchas do tipo "poço", por atrair os indivíduos para uma área com maior mortalidade (Simberloff \& Cox 1987; Henein

35 \& Merriam 1990; Bennet 1999). No entanto, ao longo do tempo, estudos sobre o tema foram se acumulando na literatura, e a conclusão de muitos trabalhos de revisão da literatura afirmam que há mais indicações de efeitos positivos do que de efeitos negativos em estudos empíricos, mas que os resultados ainda são idiossincráticos e por vezes controversos (Hobbs 1992; Beier \& Noss 1998; Haddad et al. 2003; MacDonald 2003; Haddad \& Tewksbury 2006; Gilbert-Norton et al. 2010).

Entre os estudos empíricos que identificaram resultados positivos da presença de corredores para a dispersão de organismos, encontram-se trabalhos com onças pardas (Beier 1995), pequenos mamíferos (Bennett 1990; Bennett et al. 1994; Pardini et al. 2005), borboletas (Haddad \& Baum 1999) e aves (Bentley \& Catterall 1997; Lees \& Peres 2008). No entanto, resultados menos claros, com algumas espécies se beneficiando da presença de corredores e outras não, foram observados também pequenos mamíferos (Lindenmayer et al. 1993; Bowne et al. 1999; Danielson \& Hubbard 2000), lagartos (Dixo \& Metzger 2009) e insetos (Collinge 2000).

Como explicação para os resultados conflitantes observados depois de uma década de estudos empíricos e manipulativos, sugerem-se as falhas de replicação nos estudos, a presença de fatores sinergéticos não levados em conta pelos estudos (como o efeito da área, o impacto da matriz, a proximidade a estradas e cidades, etc.) e a escala dos estudos (Beier \& Noss 1998; Haddad \& Tewksbury 2006). Enquanto estudos experimentais e manipulativos são defendidos por corrigirem alguns desses complicadores (Inglis \& Underwood 1992), outros autores defendem que a utilidade desses estudos é limitada e a extrapolação de seus resultados é problemática, pois geralmente são realizados em escalas mais finas do que as escalas do processo real de fragmentação e geralmente com grupos de fácil manipulação, que não são de interesse real de conservação (Harrison 1992; Noss \& Beier 2000).

O efeito positivo da presença de corredores pela facilitação do movimento devem ser especialmente relevantes para aquelas espécies que apresentam áreas de vida maior do que a média da área dos fragmentos (Rosenberg et al. 1997) e que evitam a dispersão pela matriz 
antrópica (Haddad \& Tewksbury 2006). Por outro lado, o uso dos corredores como hábitat por algumas espécies com áreas de vida pequenas, apesar de não contribuir diretamente para a taxa de movimento pelo corredor, deve ser indicativo de que o corredor também cumpre sua função de conector (Beier \& Loe 1992; Bennett et al. 1994). No entanto, deve-se manter em mente que a área de vida por si só, assim como características básicas comportamentais e morfológicas, não é suficiente para prever o comportamento das espécies em corredores e o sucesso na dispersão (Lidicker \& Koenig 1996). Como ressaltado por Lidicker Jr. (1999), a maneira com a qual uma espécie se comporta em ambientes dominados pelo efeitos de borda (que é basicamente o caso em corredores lineares; Hobbs 1992; Matlack \& Litvaitis 1999; Hilty et al. 2006) deve ser o principal fator explicativo do sucesso daquele grupo na utilização do corredor.

Para que as espécies sensíveis à matriz e ao efeito de borda possam escolher e percorrer com sucesso um corredor, este deve ser de preferência largo (Bennett 1999), curto (Wilson \& Lindenmayer 1995) e de boa qualidade estrutural interna (Harrison 1992; Bennett et al. 1994).

75 Para se atingir o objetivo da criação ou manutenção de corredores, Lindenmayer e Nix (1993) recomendam, ainda, considerar a configuração geral do corredor na paisagem. Na literatura, sugere-se que a maximização da largura é a forma mais prática de aumentar o sucesso do uso dos corredores, pela diminuição do efeito de borda, mas pode, por outro lado, aumentar o tempo de trânsito no corredor, diminuindo o sucesso na dispersão através dele (Harrison 1992; Andreassen et al. 1996; Rosenberg et al. 1998; Lidicker Jr. 1999).

As discussões sobre o valor dos corredores ecológicos como estratégia de manejo já não é mais tão acirrada como foi nas décadas de 1980 e 1990, mas estudos empíricos ainda são frequentemente feitos para tentar resolver as idiossincrasias observadas. No entanto, os corredores já são uma das estratégias de manejo mais recomendadas e implementadas na prática.

85 Críticos de corredores ecológicos afirmam que o custo de se alocar recursos para implementar corredores entre fragmentos é alto demais para um elemento de paisagem tão controverso (Simberloff \& Cox 1987; Simberloff et al. 1992; Rosenberg et al. 1997). Segundo eles, a conservação de novos fragmentos, mesmo que isolados, traria mais benefícios à persistência da diversidade regional do que elementos lineares, que discutivelmente aumentam a conectividade entre fragmentos, mas não acrescentam hábitat de qualidade à paisagem como um todo.

No Brasil, no entanto, já está prevista a necessidade de manutenção dos remanescentes ripários como área de proteção permanente (APPs) nas propriedades rurais de todo o território 
nacional, e a discussão do potencial dos corredores ecológicos tem valor na defesa desse instrumento como oportunidade de manejo nas paisagens brasileiras. As APPs têm como objetivo primário a preservação dos recursos hídricos (Laurance \& Gascon 1997), e quando adequadamente mantidas, apresentam um elemento linear de conexão ubíquo em toda a paisagem. A preservação desses elementos não incorre em custo adicional de conservação e eles são uma oportunidade clara de se criar uma rede abrangente de corredores ecológicos. Defendese que mesmo que essas áreas não conectem necessariamente dois fragmentos de grande importância biológica, eles devem contribuir para a manutenção da conectividade da paisagem como um todo (Hawes et al. 2008). Além disso, ambientes ripários, e consequentemente as APPs, são um repositório de biodiversidade (Hilty et al. 2006; Hilty \& Merenlender 2004), já que quase todos os elementos da fauna utilizam ambientes ripários em algum processo de seu ciclo de vida (Naiman et al. 1993). Essas circunstâncias oferecem a oportunidade de tratar essas áreas como corredores ecológicos ripários, com o potencial de fornecer conectividade para diversos grupos ameaçados pelo avanço do desmatamento e pela consequente perda e fragmentação de hábitat. Esse estudo visará, portanto, revisar o conhecimento sobre o papel das áreas de preservação permanente (APPs) como conectores de paisagem para diversos grupos animais no Brasil.

\section{Conceitos de corredores ecológicos e suas aplicações no Brasil}

Antes de proceder na discussão sobre o valor das área de preservação permanente como corredores ecológicos, devemos discutir as definições de corredor ecológico utilizadas na literatura e com aplicações específicas no Brasil. Há uma miríade de conceitos sobre corredores ecológicos, que podem diferir com relação à função, à estrutura e à escala (Noss \& Daly 2006). Uma variedade de termos pode ser localizada, incluindo: corredor ecológico, corredor de biodiversidade, corredor de fauna, corredor de vida selvagem, entre outros (Hess \& Fischer 2001). Entre as definições funcionais, ressaltam-se as de conector ou hábitat (Noss 1993), barreiras ou filtros, e fonte ou sumidouro (Pulliam 1988). No entanto, de especial interesse, está

120 a distinção entre dois conceitos do termo corredores ecológicos, que variam com relação à escala: corredores ecológicos regionais e corredores lineares locais. 
Corredores ecológicos regionais consideram o arquipélago dos remanescentes nativos (como fragmentos stepping-stones), a variabilidade de atividades presente na matriz e, onde possível, a presença de fragmentos lineares e busca identificar maneiras abrangentes de manter os eventos de dispersão para grupos de interesse para conservação em uma escala regional ou até continental (Hilty et al. 2006; Tabarelli et al. 2010). Para se atingir esse objetivo, o desenho dos corredores deve incluir duas escalas de manejo: a manutenção de conectividade numa escala fina, identificando fatores locais de ameaça, e o zoneamento regional dos elementos da paisagem para otimizar a conectividade em larga escala, identificando fatores regionais de ameaça. Seu planejamento deve, então, levar em consideração os fatores socioeconômicos, culturais e biológicos da região (Sanderson et al. 2006).

No Brasil, esse primeiro conceito de corredor ecológico está definido na Lei 9.985/2000, que institui o Sistema Nacional de Unidades de Conservação (SNUC), como: "porções de ecossistemas naturais ou seminaturais, ligando unidades de conservação, que possibilitam entre elas o fluxo de genes e o movimento da biota, facilitando a dispersão de espécies e a recolonização de áreas degradadas, bem como a manutenção de populações que demandam para sua sobrevivência áreas com extensão maior do que aquela das unidades individuais" (SNUC, art. 2, parágrafo XIX). Apesar de se tratar de um conceito funcional, que promove a conexão entre áreas nativas remanescentes, o termo tem sua aplicação oficial no Projeto Corredores

140 Ecológicos, do Ministério do Meio Ambiente. Esse programa governamental busca realizar a gestão regional do território nacional, integrando unidades de conservação, áreas indígenas e as chamadas zonas de interstício, que incluem áreas particulares de grandes e pequenos produtores, comunidades, assentamentos, e até áreas urbanas. Essa gestão integrada tem como objetivo otimizar a conectividade a nível regional, com a manutenção dos processos ecológicos de 145 dispersão e fluxo gênico (IBAMA 2007). No âmbito desse projeto, dois corredores ecológicos regionais estão sendo planejados e gradualmente implementados: o Corredor Central da Amazônia, que abrange cerca de um terço do estado do Amazonas (52 milhões de hectares), e o Corredor Central da Mata Atlântica, que abrange 12 milhões de hectares nos estados da Bahia e do Espírito Santo, incluindo áreas marinhas. Outros corredores regionais são planejados e 150 implementados no Brasil, envolvendo outros órgãos, instituições e organizações nãogovernamentais, como por exemplo: o Corredor Ecológico Cerrado-Pantanal, que inclui quatro trechos (Emas-Taquari, Paranã-Pirineus, Chapada dos Veadeiros-Serra do Tombador e no 
Jalapão), o Corredor de Biodiversidade da Serra do Mar, o Corredor de Biodiversidade do Amapá, o Corredor Sul-Amazônico, entre outros.

A segunda abordagem define corredores ecológicos locais, ou corredores lineares, e é o conceito amplamente utilizado nos estudos empíricos na literatura de Ecologia de Paisagens, e normalmente se baseia em aspectos estruturais (Hess \& Fischer 2001). Soulé e Gilpin (1991) definem corredor de vida selvagem como 'um elemento bidimensional da paisagem que conecta dois ou mais fragmentos de hábitat da vida selvagem (animal) que eram conectados no passado 160 ...', enquanto Parminter (1998) define corredor como '...um elemento estreito ou linear que difere do elemento de paisagem adjacente em ambos os lados'. De forma semelhante, Forman e Godron (1986) caracterizaram corredores como "...fragmentos estreitos que diferem da matriz [o ambiente em qual os fragmentos de hábitat estão imersos] em ambos os seus lados". Considerando explicitamente suas funções, os corredores lineares também foram definidos como manchas contínuas e estreitas de vegetação, que facilitam o movimento entre fragmentos na paisagem e previnem o isolamento de populações animais (Merriam 1984).

Seu conceito na legislação brasileira pode ser ligado ao conceito de áreas de preservação permanentes (APP), oriunda do Código Florestal Brasileiro (anteriormente Lei 4.771/1965, Art. 1, parágrafo 2, inciso II, e atualmente, Lei 12.651/2012, Art. 3, inciso II), como "área protegida, coberta ou não por vegetação nativa, com a função ambiental de preservar os recursos hídricos, a paisagem, a estabilidade geológica, a biodiversidade, o fluxo gênico de fauna e flora, proteger o solo e assegurar o bem-estar das populações humanas". Entre os vários elementos de paisagem que são considerados APP, a função como corredor linear para a biodiversidade se dá por meio das APPs ripárias, definidas como as faixas marginais de qualquer curso d'água natural perene e 175 intermitente, cujas dimensões sofreram modificações com o novo Código Florestal (discutido abaixo).

$\mathrm{O}$ atual trabalho se baseia no segundo conceito apresentado para um corredor ecológico, que envolve a escala mais fina do planejamento para a manutenção da conectividade e, eventualmente, a atenuação dos efeitos negativos da fragmentação e isolamento de áreas nativas. O planejamento bem feito para a manutenção da conectividade nas paisagens reais envolve elementos em todas as escalas e inclui a interação dos dois níveis, de forma que os corredores lineares locais são um dos elementos a serem considerados no planejamento de corredores ecológicos regionais (Noss \& Daly 2006). Nesse sentido, o estudo empírico da importância de 
corredores lineares locais tem importância para o planejamento da conservação da conectividade 185 em larga escala.

\section{Áreas de Preservação Permanente (APPs) como corredores ecológicos}

A existência de estudos empíricos no Brasil discutindo o papel dos corredores ripários normalmente focam na confirmação de uso dos corredores por parte das espécies, cujos resultados confirmam a idiossincrasia observada na literatura, e na definição da largura de corredores adequada para manter a diversidade de grupos específicos. A comparação entre fragmentos conectados e não-conectados na Mata Atlântica indicou um efeito positivo da presença de corredores para algumas espécies. Por exemplo, pequenos mamíferos Pardini et al. (2005) observaram que a abundância e a riqueza de espécies era maior, e a diversidade beta era menor, em fragmentos conectados do que naqueles não conectados, indicando um efeito positivo dos corredores na movimentação de pequenos mamíferos na paisagem fragmentada. No caso de aves com características biológicas semelhantes, foram observadas respostas distintas à estrutura do hábitat, com uma espécie se beneficiando da conectividade provida pela presença de corredores, e outra respondendo mais à distância entre fragmentos (Uezu et al. 2005). Martensen et al. (2008) também detectaram efeitos positivos da presença de corredores para a abundância de algumas espécies de aves em fragmentos conectados. Em um estudo com lagartos, o efeito da presença de corredores não foi detectado, mas os autores reconhecem que esse resultado pode ter sido causado pelo fato de que a escala dos fragmentos na paisagem estudada não ter sido a ideal para esse tipo de análise, por ser maior do que as áreas de vida das espécies (Dixo \& Metzger 205 2009).

Florestas ripárias e a heterogeneidade ambiental provida por elas foram consideradas importantes para a fauna da anfíbios (Maltchik et al. 2008) e para queixadas (Keuroghlian \& Eaton 2008) na Mata Atlântica. Também existem evidências de uso de áreas ripárias não fragmentadas por onças-pintadas no Pantanal (Quigley \& Crawshaw Jr. 1992) e na Mata Atlântica (Cullen et al. 2005), o que sugere o potencial para que corredores ripários sejam uma estratégia de manejo adequada para esse felino. O uso de corredores ripários na Amazônia foi observado para jaguatiricas (Michalski et al. 2010a), mas o conhecimento acumulado para mamíferos terrestres de médio e grande porte ainda é escasso. 
Com relação à determinação da largura adequada para se estabelecer corredores ripários,

215 todos os estudos realizados no Brasil recomendam valores de largura de APPs maiores do que previstos em lei (30 m de cada lado de rios mais estreitos que $10 \mathrm{~m}$, que é a grande maioria dos cursos d'água em uma paisagem típica). Laurance e Gascon (1997) propõem uma largura de pelo menos 300 m para minimizar o efeito de borda no interior dos corredores na Amazônia. Lima e Gascon (1999) observaram que pequenos mamíferos e anfíbios amazônicos podem utilizar remanescentes ripários entre 140 e 190 m como hábitat, pois não detectaram diferenças na riqueza, na composição e na abundância desses grupos com relação à área ripária contínua. Um estudo realizado na Reserva Ducke, no estado do Amazonas, sugeriu que os valores de APPs previstos em lei são insuficientes para manter a heterogeneidade da comunidade de serpentes (De Fraga et al. 2011). Também na Reserva Ducke, Bueno et al. (2012) sugeriram corredores de pelo menos 400 m para proteger a heterogeneidade ambiental necessária para manter a comunidades original de aves, e esse valor confirma os resultados de um estudo com aves em corredores ripários em uma paisagem fragmentada da Amazônia (Lees \& Peres 2008). Um aumento na largura das APPs para pelo menos 120 m também foi defendida por Tubelis et al. (2004) para manter a heterogeneidade de hábitat importante para a comunidades de aves no Cerrado.

Em geral, há consenso do efeito positivo de corredores ripários para a manutenção da diversidade de grupos animais, mas a largura adequada estimada deve ser maior do que a requerida por lei. No entanto, é desejável uma consideração maior e explícita de outros fatores, além da largura, que afetam o uso de corredores pelas espécies, incluindo configuração na paisagem e qualidade (Lees \& Peres, 2008). Da mesma forma, a pergunta sobre quais espécies são mais beneficiadas pela presença de corredores ripários (e por quê) ainda não está bem resolvida, e a idiossincrasia continua sendo a regra.

Com as discussões das alterações da legislação, surgiram alguns estudos quantificando e discutindo o status atual das APPs no Brasil e estes oferecem resultados preocupantes. Um baixo grau de obediência ao Código Florestal antigo já era observado em todos os biomas. No estado 240 de São Paulo, apenas 25\% das áreas previstas para serem APPs ripárias estavam de fato preservadas (Silva et al. 2007). Na Amazônia, a situação é um pouco melhor, com 73\% das APPs preservadas no interior de propriedades privadas, mas o passivo ambiental é maior por parte dos pequenos produtores, já que a proporção de área produtiva disponível é menor no caso deles (Michalski et al. 2010b). No entanto, observa-se que existe uma importância maior dada pelos 
245 produtores em geral à proteção de áreas ripárias, do que de áreas longe de rios (Teixeira et al. 2009; Michalski et al. 2010b). Isso fornece uma oportunidade de planejamento para a preservação das reservas requeridas por lei em posições adjacentes às áreas ripárias, utilizando esses remanescentes para aumentar o tamanho das áreas ripárias, minimizando o efeito de borda nos corredores e aumentando a heterogeneidade presente dentro deles (Bueno et al. 2012). Essas 250 discussões são cruciais especialmente no momento em que temos que lidar com os prejuízos causados pela aprovação das alterações do Código Florestal.

A base técnica da importância ecológica das APPs já foi amplamente defendida na época da discussão do Projeto de Lei do novo Código Florestal (Develey \& Pongiluppi 2010; Freitas 2010; Galetti et al. 2010; Metzger 2010; Toledo et al. 2010), e a comunidade científica se 255 pronunciou, advertindo sobre a irresponsabilidade de se alterar a lei ambiental sem consulta dos especialistas (Lewinsohn 2010; Metzger et al. 2010; Michalski et al. 2010c). Juntamente com a pressão popular, várias alterações foram vetadas, e algum sucesso foi atingido no que tange a manutenção das larguras de APPs e as proporções de reserva legais para cada bioma. No entanto, a Lei aprovada (Lei 12.651/2012) apresenta mudanças que terão consequências negativas para a

260 biodiversidade, e incluem: (1) largura de APP contabilizada a partir do leito regular do rio, e não do leito máximo, o que causará a perda de áreas de várzea importantes biologicamente; (2) dispensa de recomposição de APPs dependendo do tamanho (módulo fiscal) da propriedade e dependendo da data da retirada da vegetação (definição da APP de uso consolidado que foram desmatadas antes de 22 de julho de 2008), o que diminui o passivo ambiental em todas as regiões

265 e portanto diminui a largura das APPs que deverá ser recomposto; (3) possibilidade de recomposição florestal com plantio intercalado de plantas nativas e culturas exóticas de baixo impacto, o que afeta a qualidade estrutural da vegetação presente nas APPs; (4) possibilidade de contabilizar a APP no cálculo da reserva legal, o que diminui a área nativa total remanescente na região; e (5) possibilidade de recomposição da cota de reserva legal em outra propriedade no 270 mesmo bioma, isentando o produtor da obrigação de compensar o impacto no local, o que representará uma maior área nativa total alocada em regiões em que a terra é barata e improdutiva, sem considerar o valor biológico da região desmatada.

Essas alterações terão consequências emergentes nos sistemas ecológicos e a perda de biodiversidade que se deve esperar pela maior retirada e diminuição das larguras e da integridade 275 vegetacional das APPs ripárias ainda não é completamente compreendida. Necessitamos, 
portanto, preencher as lacunas empíricas sobre corredores ripários que contribuam para acumular conhecimento sobre o uso desses elementos pela fauna e sobre os impactos das alterações que iremos observar ao longo do tempo, em uma escala local e regional. Principalmente, é preciso avaliar fatores pouco explorados sobre o tema, como o papel da configuração da paisagem e da qualidade interna dos corredores no potencial de uso desses elementos. Esses fatores se relacionam diretamente a itens flexibilizados pela nova legislação e, ao sabermos o que esperar frente às alterações, teremos maior habilidade em planejar e indicar medidas mitigadoras.

\section{Referências}

Andreassen H.P., Halle S., \& Ims R.A. (1996) Optimal Width of Movement Corridors for Root Voles: Not Too Narrow and Not Too Wide. Journal of Applied Ecology, 33, 63-70.

Beier P. (1995) Dispersal of Juvenile Cougars in Fragmented Habitat. The Journal of Wildlife Management, 59, 228-237.

Beier P. \& Loe S. (1992) In My Experience: A Checklist for Evaluating Impacts to Wildlife Movement Corridors. Wildlife Society Bulletin, 20, 434-440.

Beier P. \& Noss R.F. (1998) Do Habitat Corridors Provide Connectivity? Conservation Biology, 12, $1241-1252$.

Bennett A.F. (1990) Habitat corridors and the conservation of small mammals in a fragmented forest environment. Landscape Ecology, 4, 109-122.

295 Bennett A.F., Henein K., \& Merriam G. (1994) Corridor use and the elements of corridor quality: chipmunks and fencerows in a farmland mosaic. Biological Conservation, 68, 155-165.

Bennett A.F. (1999) Linkages in the Landscape: The Role of Corridors and Connectivity in Wildlife Conservation. IUCN, Gland.

Bentley J.M. \& Catterall C.P. (1997) The Use of Bushland, Corridors, and Linear Remnants by Birds in Southeastern Queensland, Australia. Conservation Biology, 11, 1173-1189.

Bowne D.R., Peles J.D., \& Barrett G.W. (1999) Effects of landscape spatial structure on movement patterns of the hispid cotton rat (Sigmodon hispidus). Landscape Ecology, 14, 53-65.

Bueno A.S., Bruno R.S., Pimentel T.P., Sanaiotti T.M., \& Magnusson W.E. (2012) The width of riparian habitats for understory birds in an Amazonian forest. Ecological Applications, 22, 722-734.

Brown J.H. \& Kodric-Brown, A. (1977) Turnover rates in insular biogeography: effects of immigration on extinction. Ecology, 58, 445-449. 
Collinge S.K. (2000) Effects of grassland fragmentation on insect species loss, colonization, and movement patterns. Ecology, 81, 2211-2226.

Cullen Jr L., Abreu K.C., Sana D., \& Nava, A.F.D. Jaguars as landscape detectives for the upper Paraná River corridor, Brazil. Natureza \& Conservação, 3, 43-58.

Danielson B.J. \& Hubbard M.W. (2000) The influence of corridors on the movement behavior of individual Peromyscus polionotus in experimental landscapes. Landscape Ecology, 15, 323-331.

Develey P.F. \& Pongiluppi T. (2010) Impactos potenciais na avifauna decorrentes das alterações propostas para o Código Florestal Brasileiro. Biota Neotropica, 10, 43-45.

Dixo M. \& Metzger J.P. (2009) Are corridors, fragment size and forest structure important for the conservation of leaf-litter lizards in a fragmented landscape? Oryx, 43, 435.

De Fraga R., Lima A.P., \& Magnusson W.E. (2011) Mesoscale spatial ecology of a tropical snake assemblage: the width of riparian corridors in central Amazonia. Herpetological Journal, 21, 51-57.

Forman R.T.T., \& Godron M. (1986) Landscape Ecology. Wiley, New York.

Freitas A.V.L. (2010) Impactos potenciais das mudanças propostas no Código Florestal Brasileiro sobre as borboletas. Biota Neotropica, 10, 53-57.

Galetti M., Pardini R., Duarte J.M.B., Silva V.M.F., Rossi A., \& Peres C.A. (2010) Mudanças no Código Florestal e seu impacto na ecologia e diversidade dos mamíferos no Brasil. Biota Neotropica, 10, $47-52$.

325 Gilbert-Norton L., Wilson R., Stevens J.R., \& Beard K.H. (2010) A meta-analytic review of corridor effectiveness. Conservation Biology, 24, 660-668.

Gonzalez A., Lawton J.H., Gilbert F.S., Blackburn T.M., \& Evans-Freke I. (1998) Metapopulation Dynamics, Abundance, and Distribution in a Microecosystem. Science, 2045, 2045-2047.

Haddad N.M. \& Baum K.A. (1999) An experimental test of corridor effects on butterfly densities. Ecological Applications, 9, 623-633.

Haddad N.M., Bowne D.R., Cunningham A., Danielson B.J., Levey D.J., Sargent S., \& Spira T. (2003) Corridor Use By Diverse Taxa. Ecology, 84, 609-615.

Haddad N.M., \& Tewksbury J.J (2006) Impacts of corridors on populations and communities. In: Crooks K.R. \& Sanjayan M. (Eds.) Connectivity Conservation. Cambridge Univeristy Press. Cambridge.

335 Hanski I. (1998) Metapopulation dynamics. Nature, 396, 41-49.

Harrison R.L. (1992) Toward a Theory of Inter-Refuge Corridor Design. Conservation Biology, 6, 293295.

Hawes J., Barlow J., Gardner T.A., \& Peres C.A. (2008) The value of forest strips for understorey birds in an Amazonian plantation landscape. Biological Conservation, 141, 2262-2278. 
Henein K.M., \& Merriam G. (1990) The elements of connectivity where corridor quality is variable. Landscape Ecology, 4, 157-1 70.

Hess G.R. \& Fischer R.A. (2001) Communicating clearly about conservation corridors. Landscape and Urban Planning, 55, 195-208.

Hilty J.A. \& Merenlender A.M. (2004) Use of Riparian Corridors and Vineyards by Mammalian Predators in Northern California. Conservation Biology, 18, 126-135.

Hilty J.A., Lidicker Jr W.Z, \& Merenlender A.M. 2006. Corridor ecology: the science and practice of linking landscapes for biodiversity conservation. Island Press, Washington D.C.

Hobbs R.J. (1992) The Role of Corridors in Conservation: Solution or Bandwagon? Trends in ecology \& evolution, 7, 389-392.

IBAMA (Instituto Brasileiro do Meio Ambiente e dos Recursos Naturais Renováveis). (2007) Projeto Corredores Ecológicos: experiências em planejamento e implementação. Ministério do Meio Ambiente, Secretaria de Biodiversidade e Florestas. Brasília.

Inglis G. \& Underwood A.J. (1992) Comments on Some Designs Proposed for Experiments on the Biological Importance of Corridors. Conservation Biology, 6, 581-586.

355 Keuroghlian a. \& Eaton D.P. (2008) Importance of rare habitats and riparian zones in a tropical forest fragment: preferential use by Tayassu pecari , a wide-ranging frugivore. Journal of Zoology, 275, 283-293.

Laurance W.F. \& Gascon C. (1997) How to Creatively Fragment a Landscape. Conservation Biology, 11, 577-579.

Lees A.C. \& Peres C.A. (2008) Conservation value of remnant riparian forest corridors of varying quality for amazonian birds and mammals. Conservation Biology, 22, 439-449.

Lewinsohn T.M. (2010) A ABECO e o Código Florestal Brasileiro. Natureza \& Conservação, 08, 100102.

Lidicker Jr W.Z., \& Koenig W.D. (1996) Responses of terrestrial vertebrates to habitat edges and corridors. In: McCullough D.R. (Ed.), Metapopulations and Wildlife Conservation. Island Press, Washington D.C.

Lidicker Jr. W.Z. (1999) Responses of mammals to habitat edges: an overview. Landscape Ecology, 14, 333-343.

Lima M. \& Gascon C. (1999) The conservation value of linear forest remnants in central Amazonia. Biological Conservation, 91, 241-247.

Lindenmayer D.B., Cunningham R.B., \& Donnelly C.F. (1993) The conservation of arboreal marsupials in the montane ash forests of the central highlands of victoria, south-east australia, IV. The presence and abundance of arboreal marsupials in retained linear habitats (wildlife corridors) within logged forest. Biological Conservation, 66, 207-221. 
Lindenmayer D.B. \& Nix H.A. (1993) Ecological Principles for the Design of Wildlife Corridors. Conservation Biology, 7, 627-630.

MacArthur R.H., \& Wilson E.O. (1967) The Theory of Island Biogeography. Princeton University Press, Princeton.

MacDonald M.A. (2003) The role of corridors in biodiversity conservation in production forest landscapes: a literature review. Tasforests, 14, 41-52.

Matlack G.R., \& Litvaitis J.A. (1999) Forest edges. In: Hunter Jr M.L. (Ed.) Maintaining Biodiversity in Forest Ecosystems. Cambridge University Press. Cambridge.

Maltchik L., Peixoto C.D., Stenert C., Moreira L.F.B., \& Machado I.F. (2008) Dynamics of the terrestrial amphibian assemblage in a flooded riparian forest fragment in a Neotropical region in the south of Brazil. Brazilian Journal of Biology, 68, 763-9.

Martensen A.C., Pimentel R.G., \& Metzger J.P. (2008) Relative effects of fragment size and connectivity on bird community in the Atlantic Rain Forest: Implications for conservation. Biological Conservation, 141, 2184-2192.

Merriam G. (1984) Connectivity: a fundamental ecological characteristic of landscape pattern. In: Brandt J., Agger P. (Eds.) Proceedings of the first international seminar on methodology in landscape ecological resources and plan-ning. International Association for Landscape Ecology. Roskilde, Denmark.

Metzger J.P. (2010) O Código Florestal tem base científica? Conservação e Natureza, 8, 92-99.

Metzger J.P., Lewinsohn T.M., Joly C.A., Verdade L.M., Martinelli L.A., \& Rodrigues R.R. (2010) Brazilian Law: Full Speed in Reverse? Science, 329, 276-277.

Michalski F., Norris D., \& Metzger J.P. (2010a) Do ocelots use riparian corridors to move across a fragmented landscape? Cat News, 53, 4-7.

Michalski F., Metzger J.P., \& Peres C.A. (2010b) Rural property size drives patterns of upland and riparian forest retention in a tropical deforestation frontier. Global Environmental Change, 20, 705712.

Michalski F., Norris D., \& Peres C.A. (2010c) No Return from Biodiversity Loss. Science, 329, 1282.

Naiman R.J., Decamps H., \& Pollock M. (1993) The role of riparian corridors in maintaining reginal biodiversity. Ecological Applications, 3, 209-212.

Noss R.F. (1987) Corridors in real landscapes: a reply to Simberloff and Cox. Conservation Biology, 1, 159-164.

Noss R.F. (1993) Wildlife corridors. In: Smith D.E. \& Hellmund P.C. (Eds.) Ecology of greenways: design and function of linear conservation areas.University of Minesotta Press, Minneapolis. 
Noss R.F. \& Beier P. (2000) Arguing over Little Things: Response to Haddad et. Conservation Biology, 14, 1546-1548.

410 Noss R.F., \& Daly K.M. 2006. Incorporating connectivity into broad-scale conservation planning. In: Crooks K.R. \& Sanjayan M. (Eds.) Connectivity Conservation. Cambridge Univeristy Press. Cambridge.

Pardini R., Souza S.M., Braga-Neto R., \& Metzger J.P. (2005) The role of forest structure, fragment size and corridors in maintaining small mammal abundance and diversity in an Atlantic forest landscape. Biological Conservation, 124, 253-266.

Parminter J. (1998) Natural disturbance ecology. In: Voller J. \& Harrison S. (Eds.) Conservation Biology Principles for Forested Landscapes. UBC Press. Vancouver.

Pulliam H.R. (1988) Sources, sinks, and population regulation. American Naturalist, 132, 652-661.

Quigley H.B. \& Crawshaw Jr. P.G. (1992) A conservation plan for the jaguar Panthera onca in the Pantanal region of Brazil. Biological Conservation, 61, 149-157.

Rosenberg D.K., Noon B.R., \& Meslow E.C. (1997) Biological Corridors: Form, Function, and Efficacy. BioScience, 47, 677-687.

Rosenberg D.K., Noon B.R., \& Meslow E.C. (1998) Compensatory behavior of Ensatina eschscholtzii in biological corridors: a field experiment. Canadian Journal of Zoology, 76, 117-133.

425 Sanderson E., Forrest J., Loucks C., Ginsberg J., Dinerstein E., Seidensticker J., Leimgruber P., Songer M., Heydlauff A., O’Brien T., Bryja G., Klenzendorf S., Wikramanayake E. (2006) Setting Priorities for the Conservation and Recovery of Wild Tigers: 2005-2015. The Technical Assessment. WCS, WWF, Smithsonian, and NFWF-STF. New York-Washington D.C.

Saunders D.A., Hobbs R.J., \& Margules C.R. (1991) Biological Consequences of Ecosystem Fragmentation: A Review. Conservation Biology, 5, 18-32.

Silva A.M., Nalon M.A., Kronka F.J.N., Alvares C.A., Camargo P.B., \& Martinelli L.A. (2007) Historical land-cover/use in different slope and riparian buffer zones in watersheds of the state of São Paulo, Brazil. Sci. Agric. (Piracicaba, Braz.), 64, 325-335.

Simberloff D. \& Cox J. (1987) Consequences and Costs of Conservation Corridors. Conservation Biology, 1, 63-71.

Simberloff D., Farr J.A., Cox J., \& Mehlman D.W. 1992. Movement corridors: conservation bargains or poor investments? Conservation Biology, 6, 493-504.

Soulé M.E. \& Gilpin M.E. (1991) The theory of wildlife corridor capability. In: Saunders D.A. \& Hobbs R.J. (Eds.) Nature Conservation 2: The Role of Corridors. Surrey Beatty and Sons, Chipping Norton. 
Tabarelli M., Aguiar A.V., Ribeiro M.C., Metzger J.P., \& Peres C.A. (2010) Prospects for biodiversity conservation in the Atlantic Forest: Lessons from aging human-modified landscapes. Biological Conservation, 143, 2328-2340.

Teixeira A.M.G., Soares-filho B.S., Freitas S.R., \& Metzger J.P. (2009) Forest Ecology and Management Modeling landscape dynamics in an Atlantic Rainforest region: Implications for conservation.

Forest Ecology and Management journal, 257, 1219-1230.

Toledo L.F., Carvalho-e-Silva S.P. de, Sánchez C., Almeida M.A. de, \& Haddad C.F.B. (2010) A revisão do Código Florestal Brasileiro: impactos negativos para a conservação dos anfíbios Introdução Resultados e Discussão Métodos. Biota Neotropica, 10, 36-38.

450 Tubelis D.P., Cowling A., \& Donnelly C. (2004) Landscape supplementation in adjacent savannas and its implications for the design of corridors for forest birds in the central Cerrado, Brazil. Biological Conservation, 118, 353-364.

Wilson A.M., \& Lindenmayer D.B. (1995) The role of wildlife corridors in the conservation of biodiversity: a review. A report prepared for the National Corridors of Green Program, Greening Australia.

Uezu A., Metzger J.P., \& Vielliard J.M.E. (2005) Effects of structural and functional connectivity and patch size on the abundance of seven Atlantic Forest bird species. Biological Conservation, 123, 507-519. 


\title{
Capítulo 2
}

Terrestrial mammal responses to habitat structure and quality of remnant riparian forests in an Amazonian cattle-ranching landscape

Authors: Zimbres, B.; Peres, C.A.; Machado, R.B.

Capítulo submetido ao periódico Biological Conservation em 18/07/2016 (BIOC-D-16-00938)

\begin{abstract}
Extensive 1970-2010 deforestation in the Brazilian Amazon has generated a 1.5 Mha fragmented region known as the 'arc of deforestation'. Farmers and cattle ranchers throughout Brazil are legally required to set-aside riparian forest strips within their landholdings, but recent legislative changes have relaxed the strip width of these riparian forests. In this context, we assessed the functional role of riparian forest remnants as landscape connectors for medium to large-bodied terrestrial mammals in a vast fragmented landscape of southern Amazonia. We selected 38 riparian forest strips and five riparian sites within continuous forest. We installed four to five camera-traps along each riparian zone (199 camera-trap stations), and sampled the terrestrial mammal assemblage for 60 days per station during the dry seasons of 2013 and 2014. We compared mammal use of riparian forests within both continuous and highly fragmented forests, and examined the effects of corridor size, corridor habitat structure, and landscape context on species richness, composition, and functional diversity, all of which were higher in continuous forests than in riparian remnants. Forest habitat degradation was associated with overall lower species richness, whereas forest specialist species richness and functional diversity were higher in increasingly wider corridors. Compositional shifts indicate that deforestation and forest degradation favours matrix-tolerant species with lower levels of forest habitat specificity. 25 We highlight the potential of riparian corridors in maintaining landscape connectivity for forest mammals, and that both corridor width and forest degradation are key predictors of communitywide responses. Planning of riparian forest networks that can function at local to landscape scales will need to consider corridor structure and be coordinated across neighbouring landholdings.
\end{abstract}

30 Keywords: ecological corridors, forest degradation, functional diversity, landscape connectivity, riparian zones. 
Brazilian Amazonia retains $\sim 28 \%$ of the world's remaining tropical forests (FAO 2015), but has exhibited the fastest absolute tropical deforestation rates in human history (Peres et al. 2010). Deforestation over the last four decades has therefore created extensive fragmented forest landscapes with varying degrees of forest cover, largely within the so-called Amazonian 'arc of deforestation' (Fearnside 2005). This region comprises $\sim 1.5$ million $\mathrm{km}^{2}$ over 248 municipal counties of southern Amazonia that are currently dominated by cattle pastures and, to a lesser extent, cropland (IBGE-SIDRA 2016). This resulted in both the fragmentation and degradation of large tracts of once continuous forest (Soares-Filho et al. 2006). Although governmental efforts in the past decade have successfully curbed much of this trend, a recent set-back in the

45 Brazilian Forest Bill, brought forward by the political pressure exerted by agribusiness lobbyists, has caused deforestation rates to rise once again across the Brazilian Amazon (Fonseca et al. 2015). In particular, changes sanctioned by congress members have reduced the total and proportional amount of legally required forest set-asides within private landholdings. These changes are non-trivial, since over half of the land throughout Brazil lies within private properties (Sparovek et al. 2015), and there are few forest reserves in the public domain set-aside for biodiversity conservation throughout most of the 'arc of deforestation' region (Ferreira et al. 2012).

It is therefore highly relevant to understand how biodiversity, especially taxa of conservation concern, respond to forest-pasture conversion in one of Earth's most biodiverse regions. Medium and large-bodied terrestrial mammals can be used as ecological indicator taxa, since their response patterns to deforestation and forest degradation are highly idiosyncratic (Wiens et al. 1993), mainly because their ecology and patterns of habitat use are highly diverse. This includes small to large-bodied species of varying population densities, several trophic guilds from herbivores to carnivores, species using small to very large home ranges, and a diverse socioecological profile, ranging from solitary to large-group-living species (Eisenberg \& Thorington Jr. 1973). Ecological tolerance to anthropogenic land uses is also widely variable, since some species may freely venture into the modified open-habitat matrix, while others are strict forest specialists, strongly avoiding highly degraded areas (Parry et al. 2007). This ecological and behavioural diversity likely reflects both species responses to habitat loss, and 
ripple effects on ecosystem functions mediated by these species, ranging from seed dispersal to top-down control of prey populations (Ahumada et al. 2011; Pavoine \& Bonsall 2011). Strategies that aim to preserve viable mammal populations are therefore a priority for the environmental management of highly fragmented tropical forest landscapes.

Maintaining riparian corridors is one of the most widespread landscape management strategies, and by no means a new conservation tool (Beier \& Noss 1998). Brazilian law requires that a minimum riparian forest remnant should be set-aside as a 'Permanent Protection Area (APP)' within all $\sim 5.5$ million private landholdings throughout the country to protect both hydrological functions and biodiversity. Such riparian strips are ubiquitous throughout the country, providing an obvious opportunity to maintain landscape-scale connectivity through a functioning network of ecological corridors. Relict riparian strips, even where they fail to connect two ecologically important forest patches, still play a key role in maintaining overall landscape connectivity by reducing patch isolation (Hawes et al. 2008). Moreover, riparian habitats, and consequently, riparian corridors are important biodiversity repositories (Hilty et al. 2006; Hilty \& Merenlender 2004), and safeguard critical resources, since a large fraction of local faunas depend on access to water and riparian food sources (Naiman et al. 1993). However, the way in which different species use these connectors is far from straightforward, with many studies concluding that the importance of ecological corridors for biodiversity is highly idiosyncratic and should be considered on a case-by-case basis (Wiens 1989; Beier \& Loe 1992; Taylor et al. 1993; Uezu et al. 2005; Tracey 2006).

Several environmental factors have been shown to affect the performance of forest corridors as a management strategy, including (1) the structural features of corridors (e.g. width, length and continuity) (Hilty et al. 2006; Hawes et al. 2008); (2) the internal quality of the vegetation (Harrison 1992; Lees \& Peres 2008); (3) the surrounding landscape configuration (Saunders et al., 1991; Prist et al., 2012); (4) the intrusion of external disturbances from the matrix (e.g. logging activity, overgrazing by domesticated livestock) (Beier \& Noss 1998); (5) the harshness of the matrix to any given species (Umetsu et al. 2008); and (6) the quality of forest source patches connecting corridors (Lindenmayer, 1994). The extent of a forest corridor in relation to the perceived scale of an organism should also affect corridor use for dispersal, and 
ultimately discriminate those species that use corridors only as landscape connectors from those

95 that use them as integral parts of their foraging home ranges (Ricketts 2001).

Here, we assess the role of remnant riparian forests as landscape connectors for medium to large-bodied terrestrial mammals in a fragmented landscape of southern Brazilian Amazonia. In particular, we compare mammalian use of riparian forests embedded within large tracks of continuous forest from those remaining as relict habitat in highly fragmented landscape contexts.

100 We expect that community richness and functional diversity to be higher in continuous riparian forests than in remnant corridors, as well as a shift in community composition between these forest types. Secondly, we quantitatively assess corridor use by the entire mammal assemblage, and relate richness, functional diversity, and composition patterns to corridor structure and quality, and landscape context. We hypothesize that richness and functional diversity will be smaller and composition will be different in narrower and more isolated corridors of lower quality, connected to distant and smaller source patches. This study focused on observed patterns of corridor use, resulting in direct conclusions on how intrinsic features of corridors affect their use by different species, and indirect conclusions on the role of riparian corridors in maintaining landscape connectivity. We provide evidence on the importance of these riparian strips to forest vertebrate populations, thereby strengthening the technical and scientific arguments that help justify the recently embattled legal requirements to maintain effective riparian corridors in Brazil and other tropical forest countries.

Materials and methods

This study was conducted across a $16,200-\mathrm{km}^{2}$ landscape encompassing three municipal counties in the northern state of Mato Grosso, southern Brazilian Amazonia: Alta Floresta

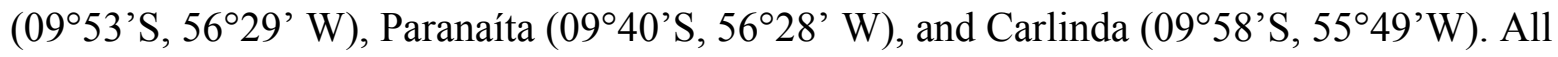
three counties were subjected to high deforestation rates in the past four decades, and collectively represent one of the most fragmented regions of the Amazonian 'arc of deforestation'. Prior to the onset of deforestation in 1978, this entire region consisted of a similar baseline mosaic of forest formations, including mostly upland (terra firme) forests and to a lesser 
extent seasonally flooded forests. However, only $\sim 53 \%$ of the study landscape currently retains its original forest cover. Although human settlement patterns vary among those three counties, their anthropogenic habitat matrix is similar, and consists primarily of extensively managed livestock pastures under low cattle stocking densities (Michalski et al. 2008).

\section{Study design}

We selected 43 sampling sites including 38 remnant riparian forest corridors of varying width, which were embedded into a cattle pasture matrix, and five intact pseudo-control riparian areas embedded within large tracts of continuous forest (> 5000 ha; Fig. 1). We defined a riparian corridor structurally, as a narrow forest remnant (relatively to its length) maintained along streams. All riparian sites were at least $1000 \mathrm{~m}$ in length and spaced apart by a minimum distance of $1,500 \mathrm{~m}$. At each sampling site, we installed four to five digital camera traps (Bushnell Trophy Cam and Reconyx HC500 HyperFire) along the riparian zone, which were spaced apart by 250-300 m. Our observational sample size thus amounted to 199 cameratrapping stations, whereas our inferential sample size consisted of 43 independent sampling areas.

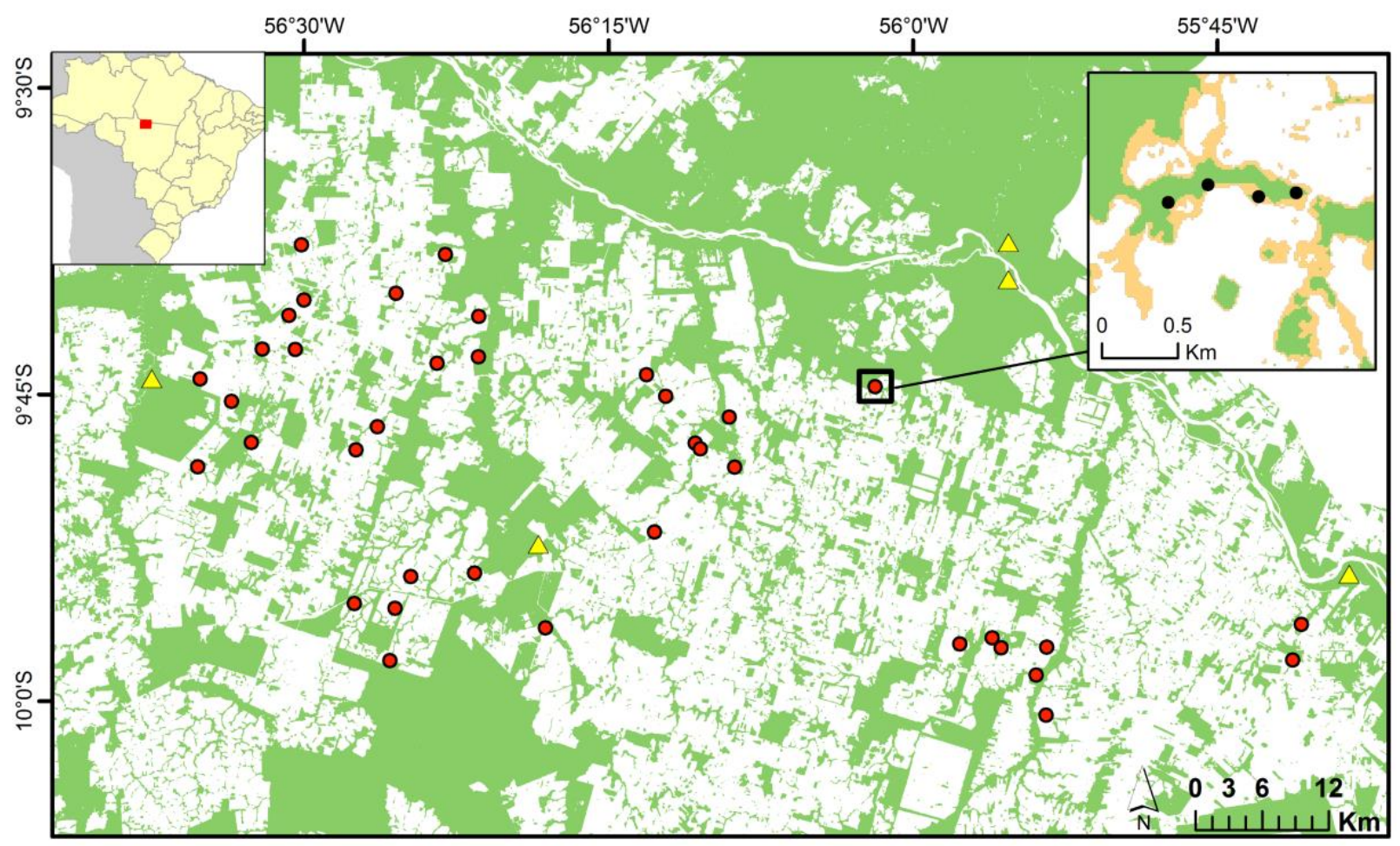


Figure 1. Study area in the northern state of Mato Grosso, Brazil, showing the 43 sampling areas including 38 remnant riparian forest corridors (red circles) and five comparable riparian areas within large tracks of continuous forest (yellow triangles). Inset map (top right) shows an example of the 4 to 5 camera trapping stations (solid circles) installed within a riparian corridor, and the two forest cover classes obtained with a supervised classification of RapidEye ${ }^{\odot}$ images

(mature closed-canopy forest in green, degraded forest in light orange). White background indicates nonforest areas consisting primarily of bovine cattle pastures.

At least 45 camera traps were used to sample batches of 10 riparian sites simultaneously for a period of 30 consecutive days. All cameras were then translocated to a new set of between seven to ten additional sites each month, until all 43 sites had been sampled over a 5-month period. This sampling schedule was deliberately restricted to the dry season (May-October), and repeated over two consecutive years (2013 and 2014). The chronological sequence of sampling across all sites was systematically rotated between years, so that sites that had been sampled at either the onset or at the end of the dry season in the first year were sampled during the peak of the dry season in the second year. We chose to restrict sampling to the dry season due to logistical reasons, including lack of physical access during the wet season, when large portions of all riparian floodplains were inundated. All camera-trap stations were baited with sardine tins pierced with multiple holes and fixed $0.75 \mathrm{~m}$ above ground on trees or poles placed in front of the cameras. Because of technical problems with some cameras and exceptional cases of camera theft, sampling of some riparian corridors were restricted to only four stations, resulting in a variable exposure time between stations considering both years of study (range $=28-62$ sampling days). This difference in sampling effort was, however, subsequently taken into account in the analyses. Consecutive camera-trapping records of the same mammal species were defined as independent if they were separated in time by a minimum interval of $24 \mathrm{~h}$.

\section{Environmental variables}

We performed a supervised classification of 43 georeferenced RapidEye scenes, with a 15-m resolution, from the years 2011-2013, which were obtained from the Brazilian Ministry of Environment. All classification procedures were conducted in ENVI 5.0 (Exelis Visual Information Solutions, Boulder, Colorado) and could resolve five mutually exclusive land cover classes: 1) closed-canopy primary forest; 2) open-canopy forest (interpreted as either degraded or secondary forest); 3) shrubby vegetation; 4) managed and unmanaged cattle pastures; 5) and eucalyptus/teak plantations. Local forest patch and landscape metrics were quantified and 
extracted in ArcGIS 10.2.2 (ESRI 2015), and included: (1) riparian corridor width (m); (2) nonlinear distance to the nearest source forest patch (m); (3) size of source forest patch (ha); (4) the total proportion of both closed-canopy and degraded forest retained within a 1,000-m buffer around the camera-trap line while excluding the area of the corridor, which we defined as 175 measure of corridor isolation in the landscape; and (5) proportion of degraded forest within a 50$\mathrm{m}$ buffer around each camera-trap station. Riparian strip width and non-linear distances from each camera-trap station to the nearest source patch were measured manually using the classified landscape map. The nearest source patch connected to each corridor was identified and isolated, and its total area quantified. This was done by generating the core areas within all forest patches across the entire landscape, defined as the forest interior area farther than $100 \mathrm{~m}$ from the nearest forest edges, and subsequently buffering those core areas at the same distance, thereby producing isolated patches that excluded narrow protrusions and connections. The first four variables above were analysed as landscape metrics, whereas the proportion of degraded forest within a 50-m buffer around each station was used as a patch metric describing corridor quality.

We also conducted in situ habitat sampling around each camera-trap station following a plotless (point-quadrant) protocol, and quantified key features of within-corridor habitat structure and vegetation status. These variables included: 1$)$ tree basal area density ( $\left.\left.\mathrm{m}^{2} / \mathrm{ha}\right), 2\right)$ understorey density, 3) number of mauritia (Mauritia flexuosa) arborescent palms, 4) and degree of bovine cattle intrusion. The first two variables were measured with a point-quadrant method, in which four points centred at each camera-trap station were placed $20 \mathrm{~m}$ apart along a parallel line to the forest-pasture edge of the corridor. At each of those points, a circle of $10-\mathrm{m}$ in radius was established and divided into four quadrants. Within each quadrant, we measured and identified the nearest tree $\geq 20 \mathrm{~cm}$ in $\mathrm{DBH}$ (diameter at breast height) and its distance to the central point. This resulted in 16 trees measured per camera-trap station, or 80 trees per riparian corridor.

195 These two measurements were then used to calculate tree basal area density for each camera-trap station. In addition, at each of the four point-quadrants, understorey density was quantified using a $200-\mathrm{cm}$ segmented pole held upright by one observer a while a second observer counted the number of $10-\mathrm{cm}$ segments that were entirely visible from a distance of $10 \mathrm{~m}$. We thus obtained four understorey density measurements for each camera-trap station, or 20 measurements per corridor. 
M. flexuosa palms represent an important food source for many terrestrial and arboreal frugivores, and their clusters typically indicate the presence of vereda habitats, which are permanently water-logged environments. From a distance of $60 \mathrm{~m}$ outside the corridor edge, we therefore visually counted all mauritia palms present within 100-m corridor segment, thus 205 providing a measure of arborescent palm density. Finally, a rank variable $(0-4)$ describing the degree of bovine cattle penetration (or intrusion) into the forest corridor was estimated based on direct observations of cattle tracks within a 30-m radial area around each camera-trap station, as following: (0) no evidence of cattle trampling; (1) rare; (2) occasional; (3) frequent; and (4) very severe trampling.

Data Analysis

Measures of terrestrial mammal species richness and functional diversity (FD) were used to assess the effects of environmental gradients associated with each corridor on the entire mammal assemblage. Estimated species richness $\left(\mathrm{S}_{\mathrm{ext}}\right)$ was generated using an extrapolation procedure based on the Chao1 estimator (Colwell et al. 2012), which estimates the number of species expected for each sampling site (camera-trap station) at the highest level of sampling effort per station (a census and recensus of 30 days $=60$ sampling days). This procedure was necessary to account for variation in sampling days due to occasional camera failure, malfunction or theft (total amount of sampling time lost due to those events amounted to $23 \%$ of an expected 286,560 camera-trap-hours under a zero-failure rate), and the variable number of stations per corridor.

220 We considered both total species richness and the richness of forest-specialists only, here defined as strict forest species that are not known to use nonforest habitats (see our classification of degree of forest-specificity below).

Species life-history traits selected to generate the FD metric included: (1) group biomass, calculated by multiplying the mean adult body size by the mean group size as reported in the 225 literature; (2) forest habitat specificity, which we classified on a scale from the least (1: frequently found in open habitats such as pasture) to the most strict forest species (3: entirely restricted to forested areas, strongly avoiding open habitats), based on the literature and our own combined field experience on the ecology of neotropical forest mammals; (3) home range size (ha); (4) a categorical measure of the main vertical locomotion strata (terrestrial, scansorial or arboreal); and (5) a trophic index, generated as a weighted mean of the energetic level of a 
species diet given the proportion of dietary items, as compiled by Wilman et al. (2014). The energetic levels considered for each diet category were assigned as an ordinal sequence including 1 (folivores: leaves), 2 (frugivores: fruit pulp), 3 (granivores: seeds), 4 (insectivore/faunivores: invertebrates), and 5 (carnivores: vertebrates). All traits assigned to each species, and the 235 references used to compile them are provided in the online Supporting Information (Table A1). From the overall trait matrix, we then calculated the observed functional diversity metric ( $\left.\mathrm{FD}_{\mathrm{obs}}\right)$ using the Euclidean distance and the unweighted paired-group clustering method. This was done by calculating arithmetic averages to generate a functional dendrogram from the trait matrix (Figure A1), and computing the branch length of the standardized tree for each sampling point

240 based on the local pool of species (S) that we recorded. In order to account for the high correlation between $\mathrm{S}$ and FD, we randomized the tips of the functional tree 1,000 times to generate an expected FD metric $\left(\mathrm{FD}_{\exp }\right)$ for each level of richness, calculated as: $\left(\mathrm{FD}_{\mathrm{obs}}-\right.$ mean $\left.\mathrm{FD}_{\text {rand }}\right)$ / sd ( $\left.\mathrm{FD}_{\text {rand }}\right)$. In doing so, we obtained a functional diversity measure that is independent of species richness, thereby indicating whether any loss in functional diversity is greater (suggesting non-random trait losses) or lower (suggesting idiosyncratic trait losses) than expected by any reduction in species richness.

Differences in S and FD between riparian forest types (corridors vs. continuous forests) were examined with likelihood-ratio tests and variance component analyses, in which the 199 camera-trap stations were nested within the 43 riparian forests. We fitted generalized linear mixed-models (GLMM) to examine the effects of corridor quality (proportion of degraded forest, tree basal area density, understorey density, M. flexuosa count, and cattle intrusion) on total species richness, richness of forest-specialists, and $\mathrm{FD}_{\mathrm{exp}}$, with a random factor for the corridor in which camera-trap stations were nested. To examine the effects of both patch and landscape variables (mean corridor width, mean distance to the nearest source patch, source patch area, and 255 isolation) on the same mammal assemblage properties, we fitted generalized linear models (GLM) for riparian corridors as a whole. First, we ascertained that there was no strong multicollinearity $(r<0.6)$ between the variables entered into the global models. We then tested for residual overdispersion of the global models, and in case this was detected, overdispersion was corrected by including an observation-level random effect (Harrison 2014). GLM models that required the overdispersion correction parameter were thus transformed into GLMM models to include the random factor. We identified meaningful predictors of community measures on the 
basis of a model selection procedure, considering all combinations of the variables included in the global models, with the Akaike Information Criterion corrected for small sample sizes (AICc, Burnham \& Anderson 2002). The relative importance of each variable was compared using their regression coefficients and unconditional standard errors generated by model-averaging. As a post-hoc analysis, we also ran a piecewise regression between corridor width (at the scale of camera-trap stations) and the response variables to assess whether this relationship was asymptotic, thereby indicating a specific width threshold that supports the highest levels of mammal species richness and functional diversity.

Community composition was analysed using a Principal Coordinate Analysis (PCoA), which ordinated the communities based on a Bray-Curtis similarity index, and identified which variables (describing both local forest habitat quality and landscape structure) significantly affected mammal species composition. We therefore based our similarity index on an imperfect proxy for abundance - temporally independent camera-trapping rates - because we considered

275 that a measure of observed incidence would be informative to elucidate patterns of corridor use, in addition to the presence/absence data. We again performed this analysis for both the entire local assemblage and forest-specialists only. Finally, to elucidate the way in which composition was changing in space, we generated metrics of $\beta$-diversity that describe which proportion of the dissimilarity between local assemblages is explained by either species loss (community nestedness) or by species replacement (community turnover) (Carvalho et al. 2011). All analyses were conducted within the R 3.1.2 platform (R Core Team 2014).

Results

We obtained 4459 independent records of 25 terrestrial mammal species during a total of 28510441 sampling days. Nine-banded armadillo (Dasypus novemcinctus), the most recorded species (1 369 independent records, 30.7\%), was detected at all corridors and all but one control continuous forest sites. Other frequently detected species occurring in most surveyed sites included lowland tapir (Tapirus terrestris, 579 records), paca (Cuniculus paca, 569 records), red-rumped agouti (Dasyprocta leporina, 325 records), and collared-peccary (Pecari tajacu, 315 records). The least detected species included jaguarundi (Puma yagouaroundi, 1 record), 
Brazilian porcupine (Coendou prehensilis, 6 records), crab-eating fox (Cerdocyon thous, 7 records), margay (Leopardus wiedii, 7 records), and bush-dog (Speothos venaticus, 9 records).

\section{Patterns of diversity}

Both observed and estimated species richness were significantly higher at riparian sites within continuous forests than those in remnant corridors, which were more variable (corridors: $S_{\text {obs }}=3$ - 19 species; continuous forests: $S_{\text {obs }}=14$ - 19 species; Table 1). The same pattern was observed for forest-specialists only, whose observed richness ranged from 12 to 15 species in continuous forests, and from 2 to 14 in corridors. Observed functional diversity, which was the most divergent metric of mammal diversity, was also significantly higher in continuous forests than in corridors (Table 1).

Table 1. Mean [SD] observed and estimated measures of diversity considered in the study, including likelihood ratio comparisons between remnant riparian forest (RF) corridors and those within continuous forest areas (significant differences shown in bold).

\begin{tabular}{|c|c|c|c|c|c|c|}
\hline \multirow[b]{2}{*}{ Variable } & \multirow[b]{2}{*}{ Corridor } & \multirow[b]{2}{*}{$\begin{array}{l}\text { Continuous } \\
\text { forest }\end{array}$} & \multirow[b]{2}{*}{$\chi^{2}$} & \multirow[b]{2}{*}{$\mathrm{p}$} & \multicolumn{2}{|c|}{ Variance explained* } \\
\hline & & & & & RF type & $\begin{array}{c}\text { Corridor } \\
\text { subset }\end{array}$ \\
\hline All species $\left(\mathrm{S}_{\mathrm{obs}}\right)$ & $6.23[2.56]$ & $8.76[2.22]$ & 10.99 & 0.0009 & 0.173 & 0.345 \\
\hline All species $\left(\mathrm{S}_{\mathrm{ext}}\right)$ & $8.23[4.68]$ & $12.20[5.12]$ & 12.33 & 0.0004 & 0.077 & 0.155 \\
\hline $\begin{array}{l}\text { Forest specialists } \\
\left(\mathrm{S}_{\mathrm{obs}}\right)\end{array}$ & $4.68[2.38]$ & $7.48[1.83]$ & 13.48 & 0.0002 & 0.212 & 0.423 \\
\hline $\begin{array}{l}\text { Forest specialists } \\
\left(\mathrm{S}_{\mathrm{ext}}\right)\end{array}$ & $6.12[4.08]$ & $9.96[3.46]$ & 14.48 & 0.0001 & 0.092 & 0.184 \\
\hline $\begin{array}{l}\text { Functional } \\
\text { diversity, FD }\end{array}$ & $3.80[1.28]$ & $5.08[0.99]$ & 9.65 & 0.0018 & 0.369 & 0.184 \\
\hline
\end{tabular}

Models explaining estimated species richness as a function of corridor quality indicated that habitat degradation and M. flexuosa palm abundance were both associated with lower numbers of species for both the entire community and for forest-specialists only (Fig. 2 and 4). Patch structure, as measured by corridor width, however, had a positive effect on forest-specialist species richness (Fig. 2 and 4). These models also indicated that observed functional diversity 
was negatively associated with riparian forest habitat degradation and M. flexuosa abundance, but positively associated with corridor width (Fig. 3 and 5). However, when accounting for the effect of species richness on the FD metric, we failed to detect any effect of explanatory variables on expected functional diversity (Fig. 3). The relationship between riparian corridor width and all measures of mammal assemblage diversity was monotonically positive, and given the wide variation in corridors surveyed (range $=32-1359 \mathrm{~m}$ in width), we failed to detect any asymptotic tendency using piecewise regression.
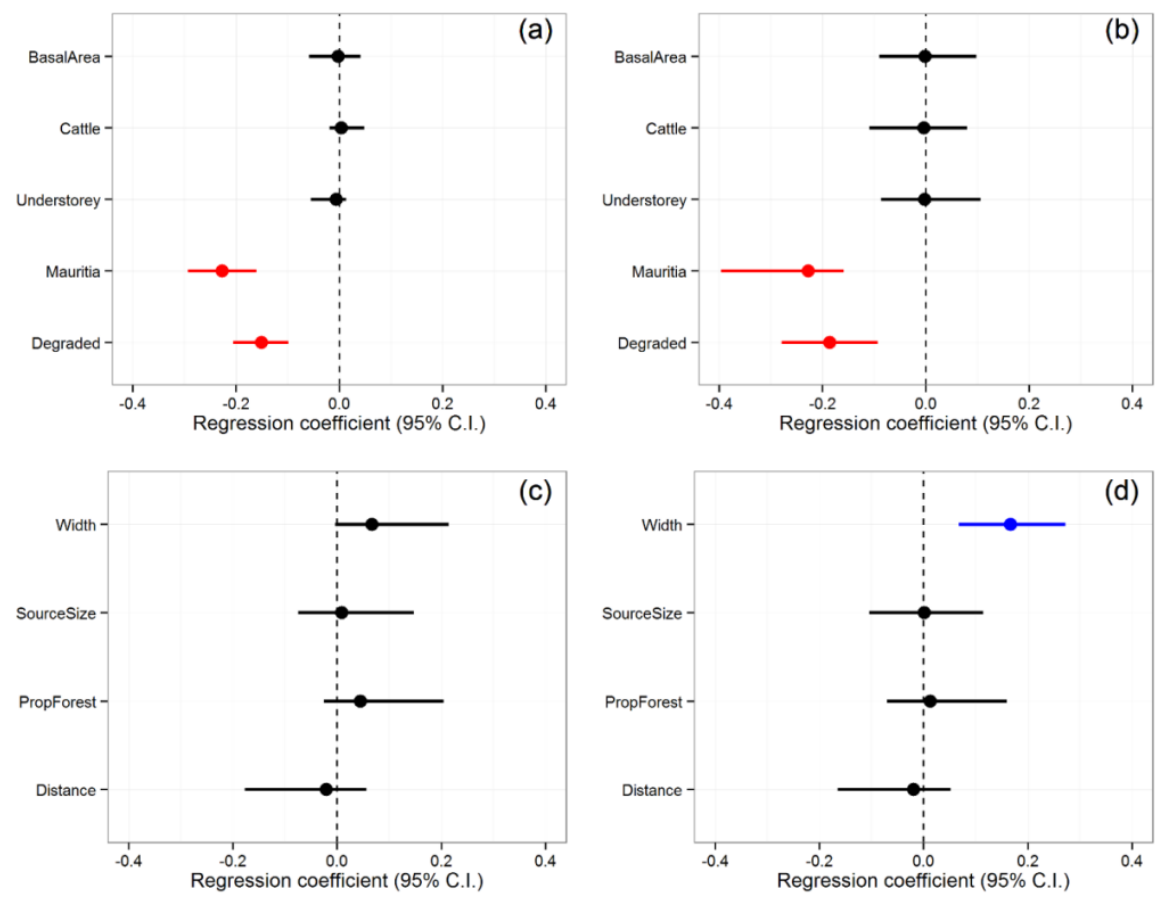

Figure 2. Regression coefficient values and confidence intervals for all variables included in the global models, and obtained by the model averaging procedure. Models generated for: (a) riparian corridor quality predictors of total estimated species richness (Chao1); (b) corridor quality predictors of estimated richness of forest-specialists (Chao1); (c) landscape structure predictors of total estimated species richness (Chao1); and (d) landscape structure predictors of richness of forest-specialists (Chao1). 

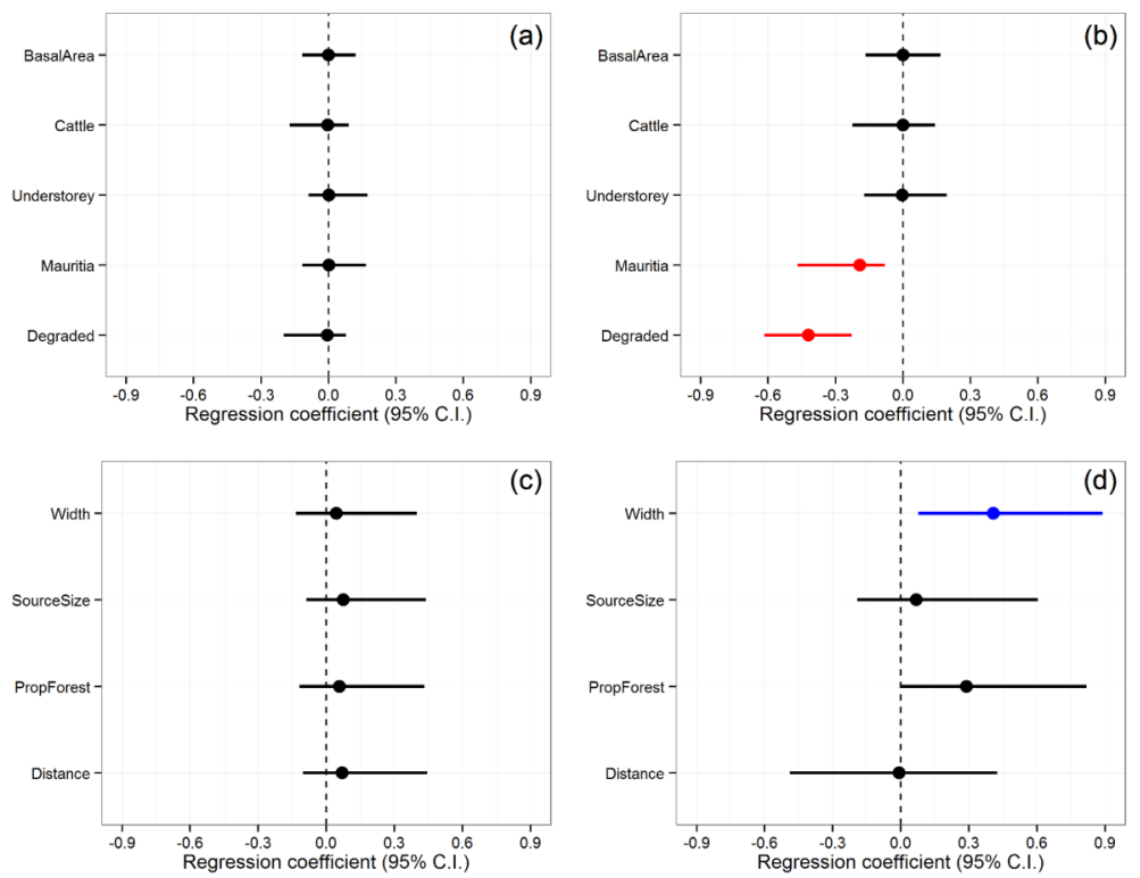

Figure 3. Regression coefficient values (and 95\% confidence intervals) for all predictors included in the global models, and obtained by the model averaging procedure. Models generated for: (a) riparian corridor quality predictors of expected functional diversity $\left(\mathrm{FD}_{\exp }\right)$; (b) riparian corridor quality predictors of observed functional diversity $\left(\mathrm{FD}_{\mathrm{obs}}\right)$; (c) landscape structure predictors of $\mathrm{FD}_{\text {exp }}$; and (d) landscape structure predictors of $\mathrm{FD}_{\mathrm{obs}}$.
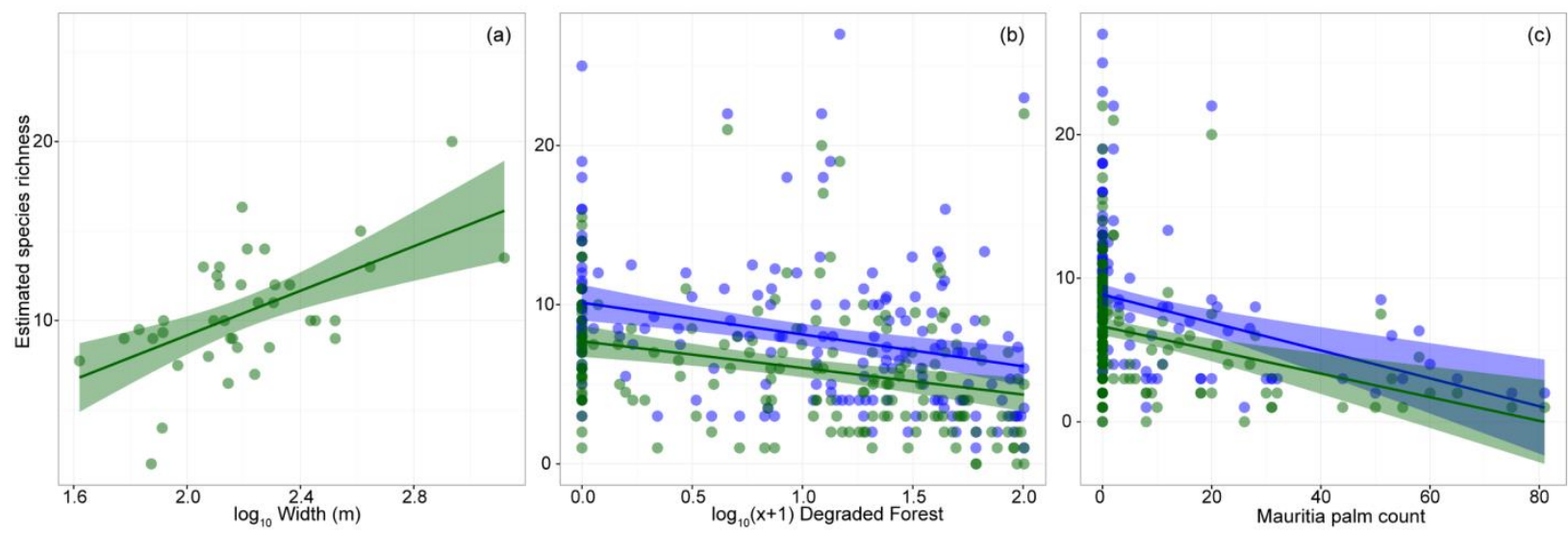

Figure 4. Relationships between estimated species richness (Chao1) and key predictors selected by the model averaging procedure, including: (a) mean riparian corridor width (m) $(n=43),(b)$ proportion of degraded forest around each camera station $(n=173)$, and (c) abundance of Mauritia flexuosa palms around each camera station $(n=173)$. Blue and green solid circles represent all terrestrial mammal species and forest-specialists, respectively. 

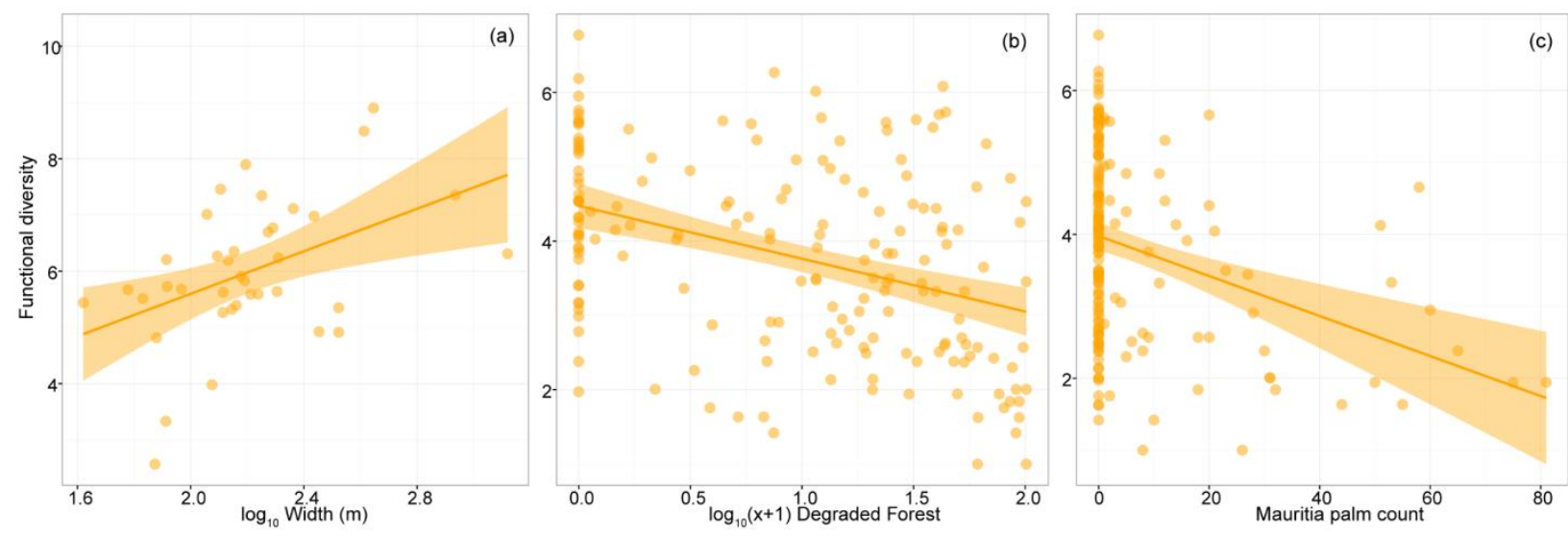

Figure 5. Predictors of observed functional diversity (FD) selected by the model averaging procedure, including: (a) mean riparian corridor width $(\mathrm{m})(\mathrm{n}=43)$, (b) proportion of degraded forest around each camera-trap station $(\mathrm{n}=173)$, and (c) Mauritia flexuosa palm count around each camera-trap station $(n=173)$.

\section{Patterns of assemblage composition}

Mammal assemblage composition in remnant riparian forests diverged from those in continuous forests, although they had a high degree of species overlap, suggesting that some corridors shared a similar set of species with riparian zones in continuous forests. Community composition varied strongly among camera trap stations within the same riparian forest (Fig. 6), and although there was a clear effect of overall species richness on these community-wide differences, species turnover played an even stronger role in explaining the dissimilarity (Fig. 6 and 7a). Measures of habitat quality that were significantly associated with these differences included $M$. flexuosa abundance and the proportion of neighbouring degraded forest for the entire assemblage, and understorey density, cattle intrusion, and mauritia abundance for forest specialists. However, community nestedness in forest specialists was more important in explaining dissimilarities than species turnover (Fig. 7b). In terms of the overall landscape structure, species replacements affected overall community dissimilarity more than did species losses, and both corridor width and corridor isolation were significantly associated with those community differences (Fig. 7c). Finally, corridor width was again significantly associated with community dissimilarity of forestspecialists, and both nestedness and species replacements explained those differences (Fig. 7d). 


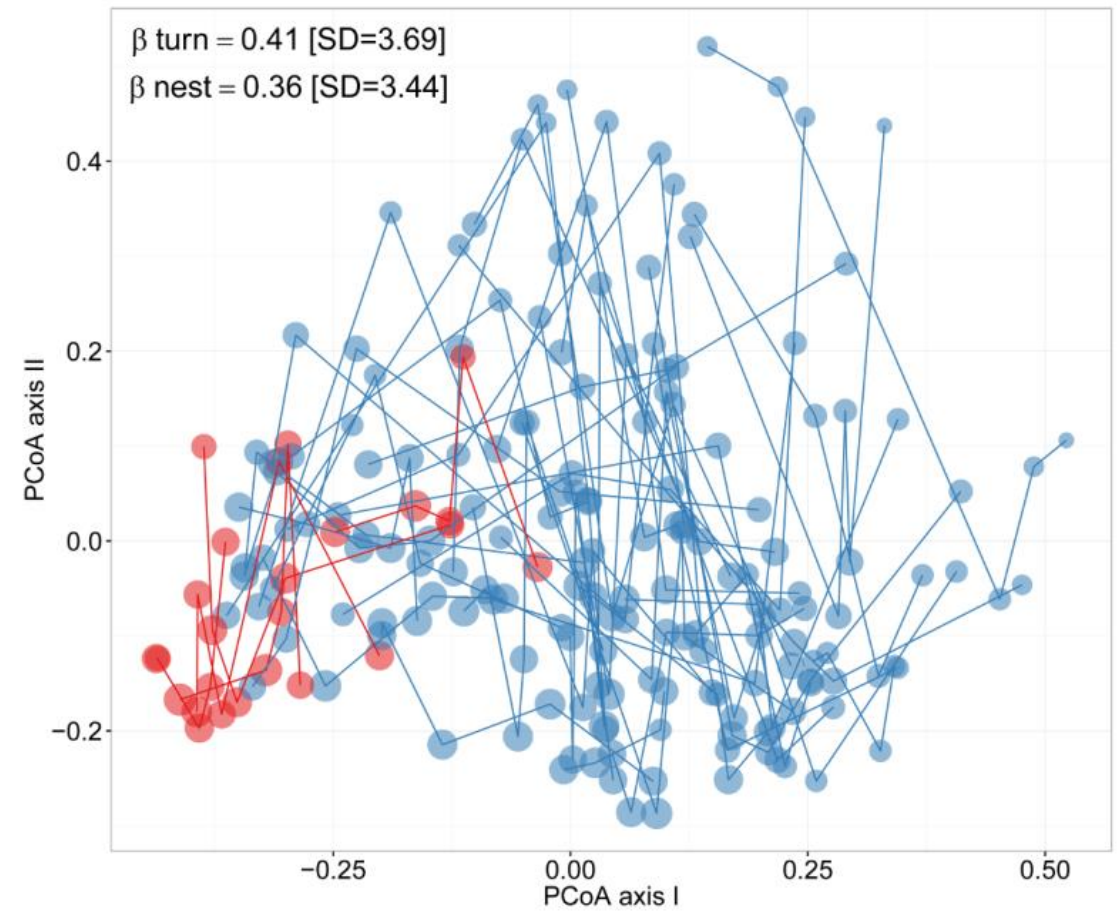

Figure 6. Principal Coordinate Analysis (PCoA) ordination of the dissimilarity of terrestrial mammal species between camera-trapping stations within remnant riparian corridors (blue circles) and continuous riparian forests (red circles) based on Bray-Curtis index. Mean [SD] of the degree to which mammal beta-diversity was accounted for by either species turnover $\left(\beta_{\text {turn }}\right)$ or community nestedness $\left(\beta_{\text {nest }}\right)$ are also shown. Size of solid circles was scaled according to the species richness observed at the scale of camera-trapping stations. 

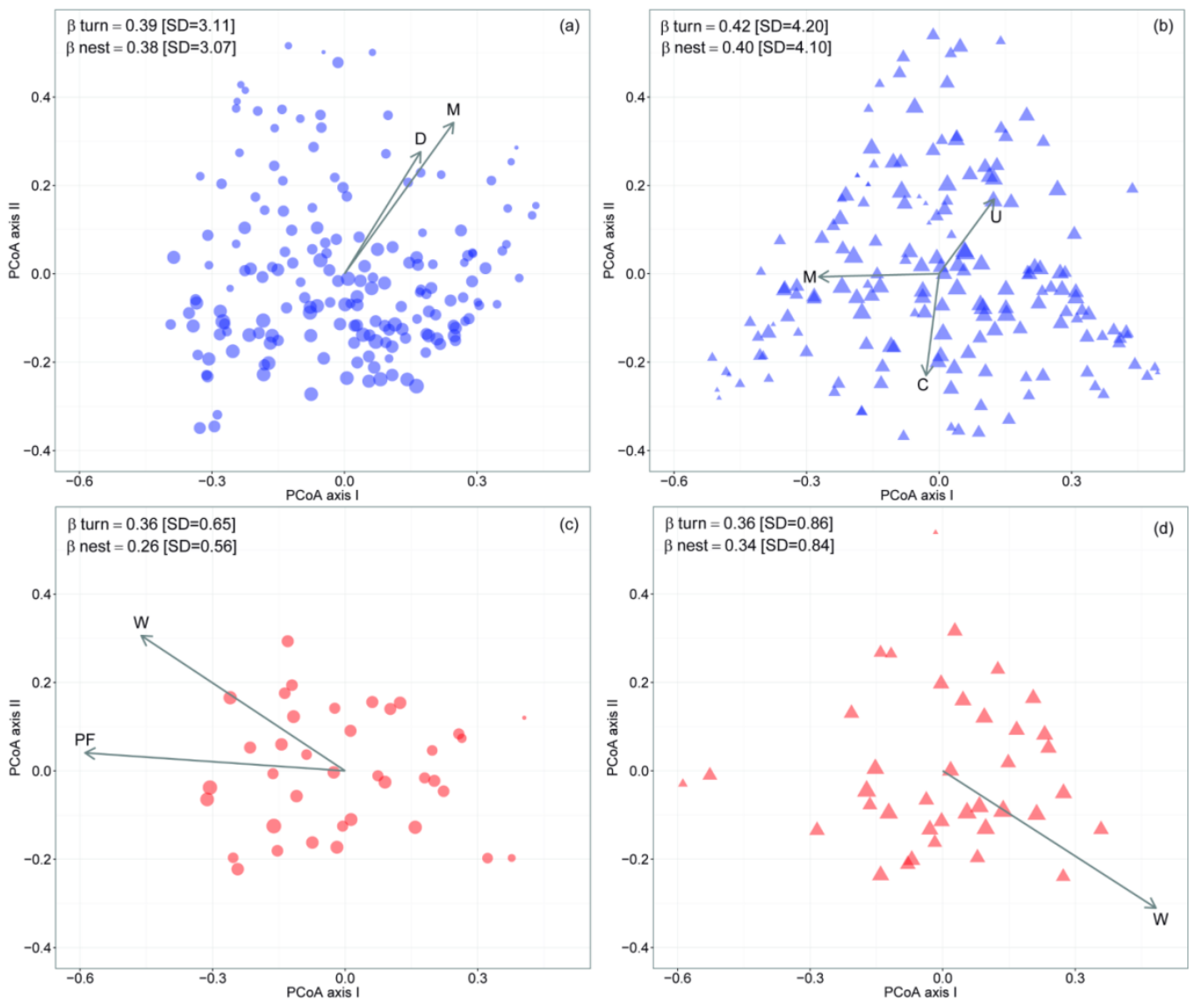

Figure 7. Principal Coordinate Analysis (PCoA) ordination of the dissimilarity between sampling points within corridors (blue symbols) and between corridors (red symbols) on the basis of BrayCurtis dissimilarity. Corridor quality (D: proportion of degraded forest around each camera-trap station; M: Mauritia palm count; C: degree of cattle intrusion; U: understorey density) or structure variables (PF: proportion of forest around the corridor; W: corridor width) that significantly affected the composition dissimilarity between mammal communities. PCoA ordination was performed considering both all terrestrial mammal species (open circles) and only species defined as forest specialists (open triangles). Beta-diversity [mean \pm SD] explained by either the species turnover $\left(\beta_{\text {turn }}\right)$ or community nestedness $\left(\beta_{\text {nest }}\right)$ are also shown. Symbol sizes are scaled according to the observed species richness.

\section{Discussion}

Riparian forest remnants present a huge potential for planning and implementing connectivity networks that can not only ensure the retention of relict forest habitat but maintain the flux of many forest species across the landscape, ultimately contributing to a healthier ecosystem functioning (Crooks \& Sanjayan 2006). However, the structure of these remnant features will ultimately determine whether or not they can effectively serve their full functional connectivity 
role for a wide range of species. In our study region in southern Amazonia, riparian forest remnants retained within private landholdings by migrant farmers less than four decades ago ranged widely in their integrity status in terms of both corridor structure and vegetation quality. We uncovered marked differences in mammal community structure between narrow $(<30 \mathrm{~m}$ 395 wide) and highly degraded corridors, and wide, high-quality corridors (up to $1200 \mathrm{~m}$ wide). Comparisons between remnant riparian strips within cattle pastures and those embedded into large continuous tracts of forest also confirmed that wide and well-preserved remnants can function as suitable habitat and/or landscape conduits for a wide range of terrestrial vertebrates. There were significant differences in species richness, species composition and functional diversity between remnant riparian corridors and riparian zones within continuous forests. However, the high mammal community overlap between wide, high-quality riparian remnants and continuous riparian sites indicate that well-preserved corridors are the best available opportunity to maintain terrestrial mammal diversity in highly deforested landscapes. This is, however, a conservative estimate of community similarity because even our continuous "pseudocontrol" sites had already been degraded to some extent, thereby serving as an imperfect baseline of the observed patterns. Although these continuous areas were embedded within exceptionally large forest fragments (>5 $000 \mathrm{ha}$ ) compared to most other forest patches remaining in the region, they do not represent the vast unbroken tracts of forests present in our study region until the late 1970 s.

As expected, the species richness of forest-specialists was higher in wide corridors. Those species are intolerant to the open habitat matrix, and are most sensitive to the multi-pronged edge effects that dominate narrow corridors (Hobbs 1992; Hilty et al. 2006). In our landscape, corridors had to be at least 100-m wide to retain the same average number of forest-dependent species typical of continuous riparian areas, although the species richness in corridors of $100-$ $415400 \mathrm{~m}$ in width was widely variable. A study in Central Amazonia also concluded that the minimum width of riparian forest set-asides as required by Brazilian legislation was clearly insufficient to maintain the heterogeneity of snake assemblages, even under the less lenient Forest Bill (De Fraga et al. 2011). Based on a multi-taxa assessment, it has been suggested that Amazonian forest corridors should be at least $300 \mathrm{~m}$ wide to minimize penetration of various 420 forms of edge effects (Laurance \& Gascon 1997). For instance, maintaining forest bird communities would require riparian corridor widths of at least $400 \mathrm{~m}$ (Lees \& Peres 2008; Bueno 
et al. 2012). Species responses to edge-dominated habitats are likely the main predictors of how corridors are used primarily as either habitat or dispersal conduits (Lovejoy et al. 1986; Lidicker 1999; Hilty et al. 2006). Edge effects can be associated with the intrusion of external

425 disturbances from the matrix and the perception of risk by sensitive species, particularly forest specialists (Laurance \& Laurance 1999; Frid \& Dill 2002).

The synergistic effects of reduced riparian corridor width and greater isolation by additional clearing of upland forests will also favour matrix-tolerant habitat generalist species, which often venture into pasture areas. The higher species turnover in increasingly isolated corridors indicates that these were used less frequently by species that rarely traverse gaps between forest remaining patches, and more frequently by those typically exhibiting matrix movements in open habitats. For example, local populations of native nonforest large herbivores, such as capybaras, are rapidly expanding in the study region, both because of greater foraging habitat availability and reduced top-down control by large felids (Michalski et al. 2006).

435 Capybaras (Hydrochaeris hydrochoerus) exploit riparian zones throughout northern Mato Grosso, further exacerbating heavy grazing pressure and modifying fluvial geomorphology, ultimately suppressing corridor regeneration. Another open-habitat species whose geographic range is rapidly expanding northward from the central Brazilian savannas is the crab-eating fox (C. thous), which is little affected by loss of landscape connectivity. We interpreted the low 440 numbers of detections of this species as evidence of ongoing population spread and/or ample use of the open-habitat matrix, rather than indicating sensitivity to forest fragmentation.

Structural forest degradation is a patch scale feature that is seldom explored, and deserves more explicit consideration (Lees \& Peres 2008; Hawes et al. 2008). Mammal species richness was depressed in more degraded forest, although this was less associated with cattle intrusion than we expected. For forest specialists, cattle intrusion only explained compositional shifts, but degradation as a whole consistently affected both total species richness and composition. Recurrent cattle access to shade and water in riparian zones induced changes in understorey structure through both overgrazing below the browse-line and excessive trampling, which often modified stream geomorphology mainly via collapsed overhanging banks (Armour 450 et al. 1991). Cattle presence may also inhibit some native mammal species, which was corroborated by the fact that compositional changes were associated with both understorey 
density and level of cattle intrusion. On the other hand, our estimates of forest degradation generated from a high-resolution remote-sensing approach mainly captured forest canopy gaps, thereby representing more severe and advanced stages of degradation, which may be caused by timber extraction and occasional wildfire events (Gerwing 2002). Although cattle trampling within riparian forests may facilitate eventual canopy openings through suppressed regeneration, signs of cattle use were most conspicuous during field sampling of the forest understorey and undetectable from satellite images.

Functional diversity was affected by species absences from narrow and degraded corridors, but specific traits did not necessarily determine which species were lost first because this effect was mediated by species losses. A relatively high ecological plasticity can be observed in several medium to large-bodied mammal species, for instance, by partially altering their diets, activity patterns or ranging behaviour to adjust to the effects of habitat loss and fragmentation (Onderdonk \& Chapman 2000; Jepsen \& Topping 2004). For example, jaguars and pumas 465 depend on forest habitats, but can often venture out into open areas particularly at night, and were recorded in a few very narrow and highly degraded corridors. Large felids in our study region are also attracted to vulnerable cattle even in the most deforested ranches, which is facilitated by hands-off herd management (Michalski et al. 2006). This pushes them farther into the dendritic network of variably connected riparian corridors. However, given that species

470 richness and functional diversity responded to the same drivers at similar rates, which could be interpreted as low functional redundancy between species (Flynn et al. 2009), a severely deforested landscape retaining only small forest patches will ultimately support a homogenized and depauperate mammal assemblage that will likely yield reduced ecosystem functions. As similarly observed for species richness, a forest corridor width of at least $125 \mathrm{~m}$ was required to 475 sustain the mean functional diversity of riparian areas within continuous forests.

Although mauritia palm clusters (veredas) provide important food sources for many ungulate and rodent species, such as the tapirs (T. terrestris), white-lipped peccaries (Tayassu pecari), and agoutis (D. leporina) (Beck 2006; Endress et al. 2013), palm density had a negative effect on mammal community structure. This can be explained by the highly degraded status of 480 veredas in the region. Veredas were dominated by mauritia palms, and consisted of poorly drained, waterlogged soils even during the dry season. Although palm swamps are also legally 
protected, the absence of a clearly-defined water course, from which to measure the buffer strip width, explains why many landowners feel entitled to convert a larger fraction of veredas than what would be required to meet their minimum APP legal compliance. This results in veredas

485 becoming the most degraded vegetation formation throughout our study area. Vereda corridors were therefore typically very narrow ( $<40 \mathrm{~m}$ wide) and waterlogged throughout, so it is unsurprising that local movement rates under these conditions were apparently low for several species. This is corroborated by the fact that large herds of white-lipped peccaries as well as the pacas were virtually never observed using these narrow corridors, despite the high abundance of 490 a preferred food resource.

We failed to detect an effect of nonlinear distance from the source forest patch on any of the response variables examined. Given the spectrum of morpho-ecological traits in terrestrial mammals $>1 \mathrm{~kg}$ considered here, some species exhibit large home ranges, great dispersal capacity, and high levels of tolerance to the anthropogenic matrix, thereby frequently travelling 495 through alternative open habitat. This contributes to the degree to which different species travel long distances through riparian corridors, and endorse the importance of this management strategy in maintaining landscape connectivity, especially for matrix-intolerant species. On the other hand, the definition of focal groups for conservation is often based on which taxa are the most demanding in terms of specific landscape attributes (Lambeck 1997). We therefore

500 highlight the fact that other vertebrate taxa may be more sensitive than medium and large-sized mammals to a number of structural corridor attributes (Lima \& Gascon 1999; Lees \& Peres 2008; Bueno et al. 2012). Although large mammals, particularly apex predators, are often considered an adequate surrogate group with large spatial requirements for planning landscapescale conservation management strategies, the requirements of different species can range

505 widely, and important mismatches in their priorities have been identified (Andelman \& Fagan 2000; Sobral et al. 2012). We therefore advise caution in extrapolating the patterns observed here for other taxonomic groups.

\section{Policy implications}

Prior to legislative changes, the Brazilian Forest Bill required landowners to set aside a permanent forest strip (APP) of at least $30 \mathrm{~m}$ on each side of rivers and perennial streams narrower than $10 \mathrm{~m}$. The more lenient current legislation prevents any further clearing, but 
bestows amnesty to landholdings up to 400 ha that failed to comply with the legislation prior to 2008 in requiring a strip width of only 5-10 m on both sides of streams, depending on landholding size. These small non-complying landholdings represent the vast majority of private

515 properties found in the study region (Michalski et al. 2010) and elsewhere in the Brazilian Amazon (Godar et al. 2014). The amount of riparian forest protection currently required by law, in terms of width, has already been shown to be insufficient (Lima \& Gascon 1999; Lees \& Peres 2008; De Fraga et al. 2011; Bueno et al. 2012), and most species, particularly forest specialists that are usually of highest conservation concern, rarely use very narrow corridors. In practice, the newly approved Forest Bill condones past illegal deforestation, effectively increasing compliance rates. However, recent deforestation monitoring reports indicate a $53 \%$ increase in the overall annual deforestation rate for the Brazilian Amazon between 2014 and 2015 (Fonseca et al. 2015).

Beyond discussions on minimum amounts of forest required, we have shown that low525 quality riparian remnants provide limited potential for maintaining metalandscape connectivity (see also Harrison 1992; Lees \& Peres 2008). Yet federal legislation in Brazil is completely omissive in terms of environmental licensing requirements concerning the quality and integrity of private forest set-asides, either before or after recent legislative changes to the Forest Bill. The vegetation along riparian set-asides can now include either primary or secondary forests in any

530 state of regeneration. Combined with an increase in forest conversion since the new (2012) Forest Bill was sanctioned, there has been a $147 \%$ increase in forest degradation across the Brazilian Amazon between 2014 and 2015 alone. Most of this rebound (85\%) was observed in Mato Grosso (Fonseca et al. 2015), the most agricultural Amazonian state where remaining forest patches are typically small and exposed to human activities such as selective logging, fires, 535 illegal mining, and hunting (Peres 2001; Gerwing 2002; Broadbent et al. 2008).

\section{Conclusions}

The potential of riparian remnants as a landscape management tool goes well beyond promoting connectivity for wildlife. They ultimately contribute to the health of hydrological ecosystem services across entire regions by acting as microclimatic and biophysical buffers, and protecting water quality and stream morphology (Naiman et al. 1993). The appropriate management of these critical landscape features therefore needs to be a priority in the face of relentless tropical 
deforestation, and should take into account a mounting body of applied landscape ecology. Although curbing deforestation can be achieved through a system of incentives and disincentives, we suggest that maintaining or restoring forest habitat quality, which remains

545 widely neglected by national policy in many tropical forest countries, needs to be explicitly considered. We suggest that managing highly fragmented tropical forest landscapes should be planned to maximize the width and integrity of riparian set-asides, while minimizing overall isolation within the landscape as well as identifying and controlling the drivers of further degradation of forest remnants. The first step in that direction should be to enforce legislative compliance from landholders, but landscape scale planning of private forest reserves should be coordinated between landholdings to create a comprehensive forest remnant network that can function at both local and regional scales.

\section{Acknowledgments}

555 We are grateful to the Brazilian Ministry of Education (CAPES) for funding BZ's PhD studentship. We thank the University of Brasilia for help in the purchase of camera traps, and the University of East Anglia for hosting BZ during a study visit. CNPq provided a research grant (\#306392/2013-5) to RBM. We also thank IdeaWild Organization, Rufford Small Grants Foundation (\#12658-1), and the National Geographic Society/Waitt Grant (\#W314-14), and a

560 CAPES grant to CAP (004-2012) for financial support for the fieldwork in Mato Grosso, Brazil. We are indebted to Danilo Fortunato for assistance in data analyses, and all landowners for granting access to their properties.

\section{References}

565 Ahumada JA et al. 2011. Community structure and diversity of tropical forest mammals: data from a global camera trap network. Philosophical transactions of the Royal Society of London. Series B, Biological sciences 366:2703-11.

Andelman SJ, Fagan WF. 2000. Umbrellas and flagships: efficient conservation surrogates or expensive mistakes? Proceedings of the National Academy of Sciences 97:5954-5959.

Armour CL, Duff DA, Elmore W. 1991. The effects of livestock grazing on riparian and stream ecosystems. Fisheries 16:7-12.

Beck H. 2006. A review of peccary - palm interactions and their ecological ramifications across the Neotropics. Journal of Mammalogy 87:519-530. 
Beier P, Loe S. 1992. In my experience: a checklist for evaluating impacts to wildlife movement corridors. Wildlife Society Bulletin 20:434-440.

Beier P, Noss RF. 1998. Do habitat corridors provide connectivity? Conservation Biology 12:1241-1252.

Brady MJ, McAlpine CA, Possingham HP, Miller CJ, Baxter GS. 2011. Matrix is important for mammals in landscapes with small amounts of native forest habitat. Landscape Ecology 26:617-628.

Broadbent E, Asner G, Keller M, Knapp D, Oliveira P, Silva J. 2008. Forest fragmentation and edge effects from deforestation and selective logging in the Brazilian Amazon. Biological Conservation 141:1745-1757.

Bueno AS, Bruno RS, Pimentel TP, Sanaiotti TM, Magnusson WE. 2012. The width of riparian habitats for understory birds in an Amazonian forest. Ecological Applications 22:722-734.

Burnham KP, Anderson DR. 2002. Model selection and inference: a practical informationtheoretic approach. Springer, New York.

Carvalho GH, Batalha MA, Silva IA, Cianciaruso MV, Petchey OL. 2014. Are fire, soil fertility and toxicity, water availability, plant functional diversity, and litter decomposition related in a Neotropical savanna? Oecologia 175:923-935.

Colwell RK, Chao A, Gotelli NJ, Lin S-Y, Mao CX, Chazdon RL, Longino JT. 2012. Models and estimators linking individual-based and sample-based rarefaction, extrapolation and comparison of assemblages. Journal of Plant Ecology 5:3-21.

Crooks KR, Sanjayan M. 2006. Connectivity conservation: maintaining connections for nature. $595 \quad$ Cambridge University Press, Cambridge.

De Fraga R, Lima AP, Magnusson WE. 2011. Mesoscale spatial ecology of a tropical snake assemblage: the width of riparian corridors in central Amazonia. Herpetological Journal 21:51-57.

Eisenberg JF, Thorington Jr RW. 1973. A preliminary analysis of a neotropical mammal fauna. Biotropica 5:150-161.

Endress BA, Horn CM, Gilmore MP. 2013. Mauritia flexuosa palm swamps: composition, structure and implications for conservation and management. Forest Ecology and Management 302:346-353.

ESRI. 2015. ArcGIS Desktop: Release 10.2.2. Environmental Systems Research Institute, Redlands, California.

FAO. 2015. FAO 2015 Forest Resources Assessment. http://www.fao.org/forest-resourcesassessment/current-assessment/en/ 
Fearnside PM. 2005. Deforestation in Brazilian Amazonia: history, rates, and consequences. Conservation Biology 19:680-688.

Ferreira J, Pardini R, Metzger JP, Fonseca CR, Pompeu PS, Sparovek G, Louzada J. 2012.

Towards environmentally sustainable agriculture in Brazil: challenges and opportunities for applied ecological research. Journal of Applied Ecology 49:535-541.

Flynn DFB, Gogol-Prokurat M, Nogeire T, Molinari N, Richers BT, Lin BB, Simpson N, Mayfield MM, DeClerck F. 2009. Loss of functional diversity under land use intensification across multiple taxa. Ecology Letters 12:22-33.

Fonseca A, Justino M, Souza Jr C, Veríssimo A. 2015. Deforestation report for the Brazilian Amazon (July 2015). Imazon, Belém, Brazil.

Frid A, Dill L. 2002. Human-caused disturbance stimuli as a form of predation risk. Conservation Ecology 6:11.

620 Gerwing JJ. 2002. Degradation of forests through logging and fire in the eastern Brazilian Amazon. Forest Ecology and Management 157:131-141.

Godar J, Gardner TA, Tizado EJ, Pacheco P. 2014. Actor-specific contributions to the deforestation slowdown in the Brazilian Amazon. Proceedings of the National Academy of Sciences 111:15591-15596.

625 Harrison RL. 1992. Toward a Theory of Inter-Refuge Corridor Design. Conservation Biology 6:293-295.

Harrison XA. 2014. Using observation-level random effects to model overdispersion in count data in ecology and evolution. PeerJ 2:e616.

Hawes J, Barlow J, Gardner TA, Peres CA. 2008. The value of forest strips for understorey birds in an Amazonian plantation landscape. Biological Conservation 141:2262-2278.

Hilty JA, Merenlender AM. 2004. Use of Riparian Corridors and Vineyards by Mammalian Predators in Northern California. Conservation Biology 18:126-135.

Hilty JA, Lidicker WZ, Merenlender AM. 2006. Corridor ecology: the science and practice of linking landscapes for biodiversity conservation. Island Press, Washington D.C.

635 Hobbs RJ. 1992. The Role of Corridors in Conservation: Solution or Bandwagon? Trends in ecology \& evolution 7:389-392.

IBGE/SIDRA. 2016. Instituto Brasileiro de Geografia e Estatística/Sistema de Recuperação Automática. http://www.sidra.ibge.gov.br/ 
Jepsen JU, Topping CJ. 2004. Modelling roe deer (Capreolus capreolus) in a gradient of forest fragmentation: behavioural plasticity and choice of cover. Canadian Journal of Zoology 82:1528-1541.

Lambeck RJ. 1997. Focal Species: A Multi-Species Umbrella for Nature Conservation. Conservation Biology 11:849-856.

Laurance SG, Laurance WF. 1999. Tropical wildlife corridors: use of linear rainforest remnants 645 by arboreal mammals. Biological Conservation 91:231-239.

Laurance WF, Gascon C. 1997. How to Creatively Fragment a Landscape. Conservation Biology 11:577-579.

Lees AC, Peres CA. 2008. Conservation value of remnant riparian forest corridors of varying quality for amazonian birds and mammals. Conservation Biology 22:439-449.

Lidicker WZ. 1999. Response of mammals to habitat edges: a landscape perspective 14:331.

Lima M, Gascon C. 1999. The conservation value of linear forest remnants in central Amazonia. Biological Conservation 91:241-247.

Lindenmayer DB. 1994. Wildlife corridors and the mitigation of logging impacts on fauna in wood-production forests in southeastern Australia: a review. Wildlife Research 21:323-340.

655 Lovejoy TE, et al. 2007. Impacts of livestock grazing and tree clearing on birds of woodland and riparian habitats. Conservation Biology 21:504-514.

Michalski F, Boulhosa RLP, Faria A, Peres CA. 2006. Human-wildlife conflicts in a fragmented Amazonian forest landscape: determinants of large felid depredation on livestock. Animal Conservation 9:179-188.

Michalski F, Metzger JP, Peres CA. 2010. Rural property size drives patterns of upland and riparian forest retention in a tropical deforestation frontier. Global Environmental Change 20:705-712.

Michalski F, Peres CA, Lake IR. 2008. Deforestation dynamics in a fragmented region of southern Amazonia: evaluation and future scenarios. Environmental Conservation 35:93103.

Naiman RJ., Decamps H, Pollock M. 1993. The role of riparian corridors in maintaining regional biodiversity. Ecological Applications 3:209-212.

Onderdonk DA, Chapman CA. 2000. Coping with forest fragmentation: the primates of Kibale National Park, Uganda. International Journal of Primatology 21:587-611. 
Parry L, Barlow J, Peres CA. 2007. Large-vertebrate assemblages of primary and secondary forests in the Brazilian Amazon. Journal of Tropical Ecology 23:653-662.

Pavoine S, Bonsall MB. 2011. Measuring biodiversity to explain community assembly: a unified approach. Biological Reviews 86:792-812.

Peres CA. 2001. Synergistic effects of subsistence hunting and habitat fragmentation on Amazonian forest vertebrates. Conservation Biology 15:1490-1505.

Peres CA, Gardner TA, Barlow J, Zuanon J, Michalski F, Lees AC, Vieira ICG, Moreira FMS, Feeley KJ. 2010. Biodiversity conservation in human-modified Amazonian forest landscapes. Biological Conservation 143:2314-2327.

Prist PR, Michalski F, Metzger JP. 2012. How deforestation pattern in the Amazon influences vertebrate richness and community composition. Landscape Ecology 27:799-812.

R Development Core Team. 2014. R: a language and environmental for statistical computing. R Foundation for Statistical Computing, Vienna, Austria. http://cranr-project.org

Ricketts TH. 2001. The matrix matters: effective isolation in fragmented landscapes. The American Naturalist 158:87-99.

Saunders DA, Hobbs RJ, Margules CR. 1991. Biological Consequences of Ecosystem Fragmentation: A Review. Conservation Biology 5:18-32.

Soares-Filho BS, Nepstad DC, Curran LM, Cerqueira GC, Garcia RA, Ramos CA, Voll E, McDonald A, Lefebvre P, Schlesinger P. 2006. Modelling conservation in the Amazon basin. Nature 440:520-523.

690 Sobral FL, Jardim L, Lemes P, Machado N, Loyola R, Cianciaruso MV. 2012. Spatial conservation priorities for top predators reveal mismatches among taxonomic, phylogenetic and functional diversity. Natureza \& Conservação 12:150-155.

Soler LDS, Escada MIS, Verburg PH. 2009. Quantifying deforestation and secondary forest determinants for different spatial extents in an Amazonian colonization frontier (Rondonia). Applied Geography 29:182-193.

Sparovek G, Barretto AGDOP, Matsumoto M, Berndes G. 2015. Effects of governance on availability of land for agriculture and conservation in Brazil. Environmental Science and Technology 49:10285-10293.

Taylor PD, Fahrig L, Henein K, Merriam G. 1993. Connectivity is a vital element of landscape structure. Oikos 68:571-573.

Tracey JA. 2006. Individual-based modeling as a tool for conserving connectivity. Pages 343368 in Crooks KR, Sanjayan M, editors. Connectivity conservation. Cambridge University Press, Cambridge, UK. 
Uezu A, Metzger JP, Vielliard JME. 2005. Effects of structural and functional connectivity and patch size on the abundance of seven Atlantic Forest bird species. Biological Conservation 123:507-519.

Umetsu F, Paul Metzger J, Pardini R. 2008. Importance of estimating matrix quality for modeling species distribution in complex tropical landscapes: a test with Atlantic forest small mammals. Ecography 31:359-370.

710 Wiens JA. 1989. Spatial scaling in ecology. Functional Ecology 3:385-397.

Wiens JA, Stenseth NC, Van Horne B, Ims RA. 1993. Ecological mechanisms and landscape ecology. Oikos 66:369-380.

Wilman H, Belmaker J, Jennifer S, de la Rosa C, Rivadeneira MM, Jetz W. 2014. EltonTraits 1.0: Species-level foraging attributes of the world's birds and mammals. Ecology 95:2027.

715 Wright SJ, Stoner KE, Beckman N, Corlett RT, Dirzo R, Muller-Landau HC, Nuñez-Iturri G, Peres CA, Wang BC. 2007. The plight of large animals in tropical forests and the consequences for plant regeneration. Biotropica 39:289-291. 
Supplementary material

Table A1. Species trait compilation to generate the functional diversity (FD) metric: 1) group biomass was estimated by multiplying mean body mass by the mean group size; 2) forest specificity, subjectively categorized from 1 (frequently occurring in open habitats such as the pasture matrix) to 3 (restricted to forested areas, and strongly avoiding open habitats); 3 ) trophic index, generated as a weighted mean of the energetic level of a species diet by the proportion of items found on that diet (following Wilman et al. 2014); 4) home range size (in hectares); 5) and a categorical measure of the main mode of locomotion and/or vegetation stratum (terrestrial, scansorial or arboreal).

\begin{tabular}{|c|c|c|c|c|c|c|}
\hline Species & $\begin{array}{c}\text { Group } \\
\text { mass }\end{array}$ & $\begin{array}{c}\text { Forest } \\
\text { specificity }\end{array}$ & $\begin{array}{l}\text { Trophic } \\
\text { index* }\end{array}$ & $\begin{array}{c}\text { Home } \\
\text { range size }\end{array}$ & Stratum & References \\
\hline $\begin{array}{l}\text { Cabassous } \\
\text { unicinctus }\end{array}$ & 4.80 & 1 & 80 & 101.60 & G & Reis et al. 2011, Wilman et al. 2014 \\
\hline $\begin{array}{l}\text { Cerdocyon } \\
\text { thous }\end{array}$ & 5.24 & 1 & 80 & 75.00 & G & $\begin{array}{l}\text { Bertha, A. 1982, Eisenberg \& Redford 1999, Nowak 1999, } \\
\text { Wilman et al. } 2014\end{array}$ \\
\hline $\begin{array}{c}\text { Coendou } \\
\text { prehensilis }\end{array}$ & 4.40 & 2 & 26 & 17.50 & $\mathrm{Ar}$ & Eisenberg \& Redford 1999, Nowak 1999, Wilman et al. 2014 \\
\hline Cuniculus paca & 8.17 & 2 & 36 & 3.44 & G & Nowak 1999, Pérez 1992, Wilman et al. 2014 \\
\hline $\begin{array}{l}\text { Dasyprocta } \\
\text { leporina }\end{array}$ & 3.02 & 2 & 34 & 3.00 & $\mathrm{G}$ & Nowak 1999, Wilman et al. 2014 \\
\hline $\begin{array}{c}\text { Dasypus } \\
\text { novemcinctus }\end{array}$ & 4.20 & 1 & 80 & 7.70 & G & $\begin{array}{l}\text { Eisenberg \& Redford 1999, McBee \& Baker 1982, Nowak } \\
\text { 1999, Wilman et al. } 2014\end{array}$ \\
\hline $\begin{array}{l}\text { Didelphis } \\
\text { marsupialis }\end{array}$ & 1.09 & 1 & 50 & 69.50 & $\mathrm{~S}$ & Eisenberg \& Redford 1999, Nowak 1999, Wilman et al. 2014 \\
\hline Eira barbara & 3.91 & 3 & 94 & 2000.00 & G & Eisenberg \& Redford 1999, Nowak 1999, Wilman et al. 2014 \\
\hline $\begin{array}{c}\text { Hydrochoerus } \\
\text { hydrochaeris }\end{array}$ & 962.90 & 1 & 22 & 10.40 & $\mathrm{G}$ & $\begin{array}{l}\text { Eisenberg \& Redford 1999, Mones \& Ojasti 1986, Nowak } \\
\text { 1999, Wilman et al. } 2014\end{array}$ \\
\hline $\begin{array}{l}\text { Leopardus } \\
\text { pardalis }\end{array}$ & 11.90 & 2 & 100 & 1815.00 & G & $\begin{array}{l}\text { Eisenberg \& Redford 1999, Murray \& Gardner 1997, Oliveira } \\
\text { \& Cassaro 2006, Reis et al. 2011, Wilman et al. } 2014\end{array}$ \\
\hline $\begin{array}{l}\text { Leopardus } \\
\text { wiedii }\end{array}$ & 3.25 & 3 & 88 & 500.00 & S & $\begin{array}{l}\text { Eisenberg \& Redford 1999, Oliveira \& Cassaro 2006, Oliveira } \\
\text { 1998, Reis et al. 2011, Wilman et al. } 2014\end{array}$ \\
\hline Mazama & 22.80 & 3 & 28 & 100.00 & G & Nowak 1999, Tobler et al. 2009, Wilman et al. 2014 \\
\hline
\end{tabular}




\begin{tabular}{|c|c|c|c|c|c|c|}
\hline americana & & & & & & \\
\hline Mazama sp & 16.63 & 2 & 34 & 100.00 & $\mathrm{G}$ & Nowak 1999, Tobler et al. 2009, Wilman et al. 2014 \\
\hline $\begin{array}{l}\text { Myrmecophaga } \\
\text { tridactyla }\end{array}$ & 22.33 & 1 & 80 & 370.00 & $\mathrm{G}$ & Eisenberg \& Redford 1999, Nowak 1999, Wilman et al. 2014 \\
\hline Nasua nasua & 94.85 & 3 & 56 & 445.00 & $\mathrm{~S}$ & $\begin{array}{l}\text { Eisenberg \& Redford 1999, Gompper \& Decker 1998, Reis et } \\
\text { al. 2011, Wilman et al. } 2014\end{array}$ \\
\hline Panthera onca & 100.00 & 3 & 100 & 7825.00 & $\mathrm{G}$ & $\begin{array}{l}\text { Eisenberg \& Redford 1999, Nowak 1999, Oliveira \& Cassaro } \\
\text { 2006, Wilman et al. } 2014\end{array}$ \\
\hline Pecari tajacu & 638.00 & 2 & 44 & 113.00 & $\mathrm{G}$ & Eisenberg \& Redford 1999, Nowak 1999, Wilman et al. 2014 \\
\hline $\begin{array}{l}\text { Priodontes } \\
\text { maximus }\end{array}$ & 45.36 & 3 & 80 & 1000.00 & $\mathrm{G}$ & Reis et al. 2011, Wilman et al. 2014 \\
\hline $\begin{array}{c}\text { Procyon } \\
\text { cancrivorus }\end{array}$ & 6.95 & 2 & 80 & 695.00 & $\mathrm{G}$ & Reis et al. 2011, Wilman et al. 2014 \\
\hline Puma concolor & 51.60 & 2 & 100 & 3200.00 & $\mathrm{G}$ & $\begin{array}{l}\text { Currier, M.J.P. 1983, Nowak 1999, Oliveira \& Cassaro 2006, } \\
\text { Wilman et al. } 2014\end{array}$ \\
\hline $\begin{array}{c}\text { Puma } \\
\text { yagouaroundi }\end{array}$ & 6.88 & 3 & 92 & 1330.00 & $\mathrm{G}$ & $\begin{array}{l}\text { Eisenberg \& Redford 1999, Oliveira \& Cassaro 2006, Oliveira } \\
\text { 1998, Wilson \& Mittermier 2009, Wilman et al. } 2014\end{array}$ \\
\hline $\begin{array}{l}\text { Speothos } \\
\text { venaticus }\end{array}$ & 12.00 & 3 & 100 & 690.00 & $\mathrm{G}$ & Reis et al. 2011, Wilman et al. 2014 \\
\hline $\begin{array}{l}\text { Tamandua } \\
\text { tetradactyla }\end{array}$ & 5.52 & 2 & 80 & 380.00 & $\mathrm{~S}$ & Reis et al. 2011, Wilman et al. 2014 \\
\hline $\begin{array}{l}\text { Tapirus } \\
\text { terrestris }\end{array}$ & 207.50 & 2 & 20 & 200.00 & $\mathrm{G}$ & Padilla \& Dowler 1994, Reis et al. 2011, Wilman et al. 2014 \\
\hline Tayassu pecari & 3223.37 & 3 & 44 & 1100.00 & $\mathrm{G}$ & $\begin{array}{l}\text { Eisenberg \& Redford 1999, Mayer \& Wetzel 1987, Nowak } \\
\text { 1999, Wilman et al. } 2014\end{array}$ \\
\hline
\end{tabular}

*The energy levels considered for each diet category were assigned to a rank order including 1 (foliage), 2 (fruits), 3 (seeds), 4 (invertebrates), and 5 (vertebrates or carrion). 
Figure A1. Functional dendrogram generated with the Euclidean distance and the unweighted paired-group clustering method by arithmetic averages (UPGMA) of trait values. Branch length was standardized from the root to the tips of the tree. Traits used to calculate distances between species are presented in Appendix S1.

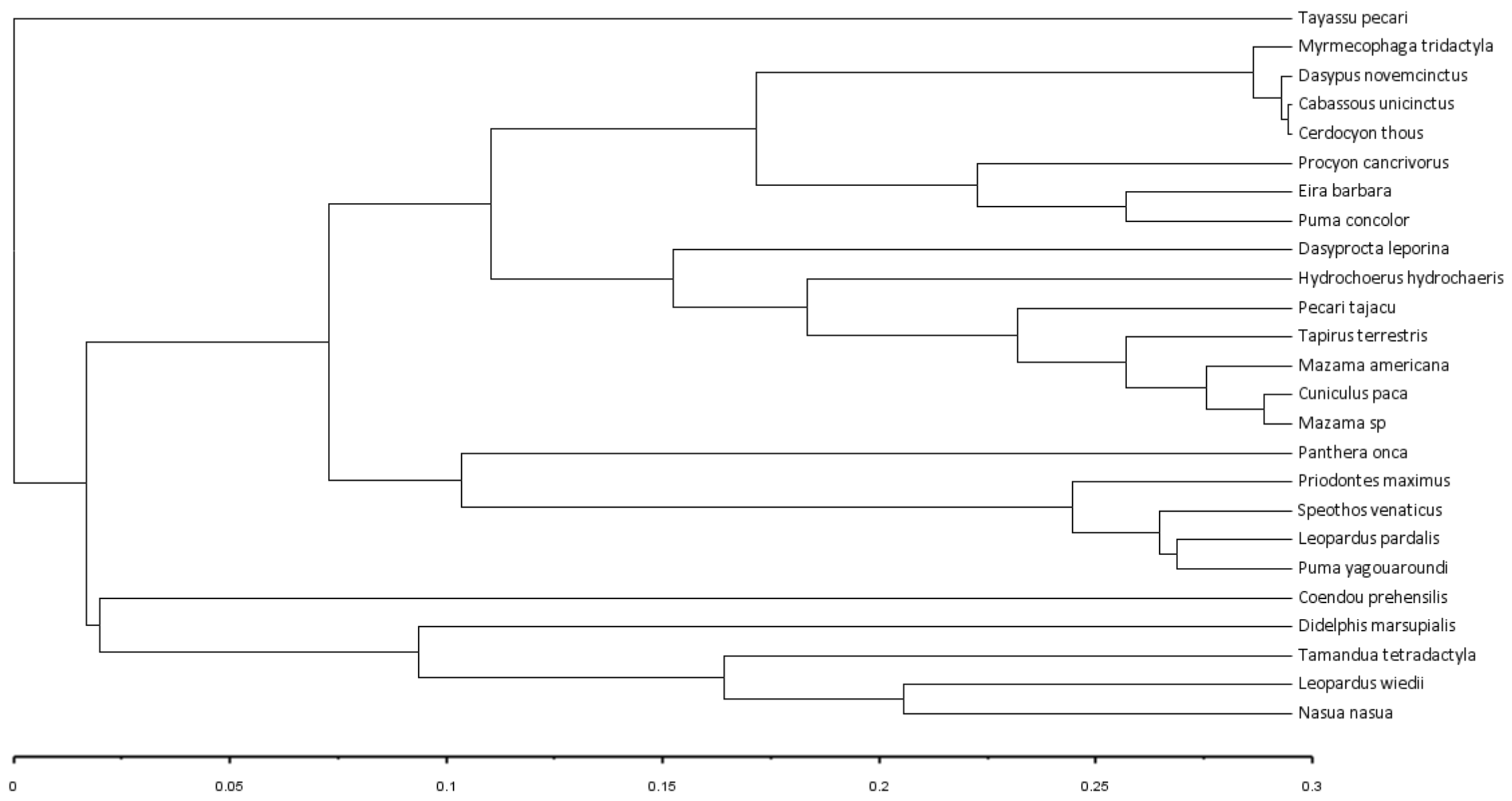




\section{Capítulo 3}

Occupancy patterns of terrestrial mammals in riparian corridors in a fragmented Amazonian

landscape

Abstract

Species permanence in a fragmented landscape depends on habitat amount and connectivity, but a structurally connected landscape may not be functionally connected, depending on the circumstances in which the species travel through connecting elements. The success of ecological corridors will be intimately related to habitat structure, quality, context, and the species' tolerance to edge effects that dominate these patches. Riparian patches are legally protected in Brazil within private landholdings, and we aimed to assess riparian corridor use in an occupancy modeling approach for terrestrial mammal species, assessing in what circumstances these species effectively use these connectors. We also extrapolated the occupancy patterns modeled for the entire study region, in order to identify which riparian remnants present the greatest potential to promote landscape connectivity for the community. We selected 38 riparian forest patches and five riparian sites within continuous forest, in which we installed four to five camera-traps (199 camera-trap stations). The terrestrial mammal community was sampled for 60 days per station during the dry seasons of 2013 and 2014. We modeled mammal occupancy and detection probabilities within riparian forest remnants, and examined the effects of corridor size, habitat quality, and landscape structure on their occupancy probabilities. Finally, we scaled-up the patterns modeled to 1,915 patches and generated a pseudo-richness map based on patch suitability according to a threshold of species occupancy. Of the ten species for which occupancy was modeled, only two did not present response to forest quality or structure. Forest degradation was the most important determinant of occupancy probability. Patch suitability was lower when considering habitat quality than structure, and higher riparian forest quality was concentrated in the southwestern portion of the study region. Beyond safeguarding legal compliance, controlling the drivers of forest degradation is necessary to promote landscape connectivity for a wide range of terrestrial species.

Keywords: connectivity, detection probability, ecological tolerance, forest degradation, spatial ecology 
Introduction

The association between habitat amount and richness patterns is usually described by the species-area relationship, which is one of the strongest tenets of conservation biology (Preston 1962; MacArthur \& Wilson 1967). However, in a highly fragmented landscape, the permanence of a given species will basically depends on both habitat amount and connectivity (Noss, 1987; Haddad \& Tewksbury, 2006). Classically, studies on landscape connectivity have addressed the difference between structural and functional connectivity, in which habitat patches may be 50 physically disconnected and isolated in the landscape (low structural connectivity), but may be suitably reached by a species, depending on their gap crossing ability and tolerance to the matrix (high functional connectivity). The opposite may also be true, in which a structurally connected landscape, comprised of a network of corridors, for instance, does not adequately function as connectors for a given group, depending on the circumstances in which a species travels through these elements (Beier \& Noss 1998). Measuring landscape connectivity, therefore, is not straightforward, and ultimately depends on the organism in question (Wiens 1989; Beier \& Loe 1992; Taylor et al. 1993; Uezu et al. 2005; Tracey 2006). This idiosyncrasy complicates the study of connectivity and the definition of management strategies that serve larger groups of species in a single landscape (Harrison 1992).

It has been suggested that strategies must be designed in accordance to the requirements of those species that are more sensitive to the process of fragmentation, but what constitutes 'sensitivity' is also not simple. Ecological and morphological traits have been related to a species' responses to anthropogenic impacts, but this approach has not succeeded in resolving the idiosyncrasies observed (Henle et al. 2004). More likely, a higher degree of sensitivity to fragmentation will be associated with how a species responds to edge-dominated habitats and their tolerance to the matrix (Lidicker 1999). Terrestrial mammals are a highly ecologically diverse group, including small to large-bodied species, belonging to several trophic guilds, with home ranges of highly variable sizes, from solitary species to those that live within large aggregations (Eisenberg \& Thorington Jr. 1973; Bodmer 1991). This ecological diversity, as well as a relatively high behavioral plasticity, produces variable responses to habitat fragmentation and structure (Wiens et al. 1993).

The success of ecological corridors as a management strategy will be intimately related to the ecological tolerance towards the modified habitat, since corridors are frequently narrow and 
therefore highly subject to the intrusion of external disturbances from the matrix (Hobbs 1992;

75 Hilty et al. 2006). Patch- and landscape-scale factors will also affect corridor potential as a connectivity management strategy, including corridor width, length, continuity (Lindenmayer \& Nix 1993; Haddad 1999; Hilty et al. 2006; Tubelis et al. 2007; Hawes et al. 2008), vegetation quality (Harrison 1992; Bennett et al. 1994; Lees \& Peres 2008), isolation in the landscape (Saunders et al. 1991; Prist et al. 2012), and the type and intensity of disturbance intrusion from the adjacent matrix (Beier \& Noss 1998; Gascon et al. 1999; Umetsu et al. 2008).

In Brazil, environmental legislation requires a minimum riparian set-aside to be kept within all private landholdings, as a Permanent Protection Area (APP). With over half of the natural vegetation within $\sim 5.5$ million private landholdings throughout the country (Sparovek et al. 2015), these APPs are the best opportunity available to the integrated planning of an ecological corridor network that serves entire landscapes at both local and regional scales. These elements potentially connect remnant forest patches, as well as function as ecologically rich habitats, since riparian zones are important biodiversity repositories (Hilty et al. 2006; Naiman et al. 1993). Moreover, riparian strips may also act in reducing overall patch isolation in the landscape, benefiting those species that have some degree of gap-crossing ability (Hawes et al. 2008). The southern part of the Brazilian Amazonia, in the so-called 'arc of deforestation', is a $\sim 1.5$ million $\mathrm{km}^{2}$ region, ideal for the investigation of riparian corridor use by animal groups, and for the assessment of these connectors' potential as a connectivity management strategy. In this region, deforestation over the last four decades has created an extensive fragmented forest landscapes, dominated by cattle pastures and cropland, with varying degrees of forest cover and legal compliance (Fearnside 2005). APPs within the region are also in a varying degree of preservation, in terms of width, forest quality, and isolation (Lees \& Peres 2008).

The potential of these riparian remnants as a management strategy for promoting landscape connectivity ultimately depends on empirical evidence of their roles as corridors for a myriad of species. However, adequate modeling of their use depends on considering both 100 occupancy and detection probabilities, since perfect detection is seldom a reality (MacKenzie et al. 2002). We therefore aimed to assess riparian corridor use in an occupancy modeling approach for different terrestrial mammal species, assessing in what circumstances these species effectively use the APPs. Specifically, we tested whether corridor use is determined by the patchstructure and internal quality of the corridors as well as by the surrounding landscape, 
105 hypothesizing that corridor width, quality, isolation, distance to and size of the nearest source patch will affect mammal occupancy probabilities, especially of more forest strict species. Moreover, we performed a scaling up exercise for the entire study region, in order to identify which riparian remnants present the greatest potential to promote a connected landscape for the terrestrial mammal community based on occupancy probabilities.

Methods

Study area

Three neighboring municipal counties were covered in our study in the Southern portion of the Brazilian Amazon, in the state of Mato Grosso: Alta Floresta (0953'S, 56 $\left.28^{\circ} 725 \mathrm{~W}\right)$, 115 Paranaíta $\left(09^{\circ} 40^{\prime} \mathrm{S}, 5^{\circ} 28^{\prime} \mathrm{W}\right)$, and Carlinda (09 $\left.58^{\prime} \mathrm{S}, 5^{\circ} 49^{\prime} \mathrm{W}\right)$. These counties are located in the Amazonian deforestation frontier, known as the 'arc of deforestation'. Land use in these landscapes is mainly comprised of cattle ranching landholding, of varying sizes, which were established in the 1980s, so that the anthropogenic matrix is widely similar within this 1620000 ha region (Michalski et al. 2008). Currently the region presents approximately 53\% of remaining native vegetation, including previously similar baseline upland and seasonally flooded forests. In addition to being highly fragmented, the remaining native patches are also subject to high levels of forest degradation, which includes logging activities, cattle intrusion and trampling, and fire.

\section{Study design}

Forty five digital camera traps (Bushnell Trophy Cam ${ }^{\mathrm{TM}}$ and Reconyx HC 500

125 HyperFire ${ }^{\mathrm{TM}}$ ) were deployed to simultaneously sample 38 riparian forest strips of varying sizes, configuration and quality, as well as five pseudo-control riparian areas immersed in continuous tracts of forest, thus totaling 43 sampling areas (Figure 1). Four to five camera traps (CT) were installed in each of these selected areas, at a distance of 250-300 m between them, so that sample size at the CT level was $n=199$ considering all sampling sites, and $n=174$ considering isolated riparian strips only. Seven to ten riparian forests were sampled during 30 days in each bout. The cameras were then swapped between areas, until all 43 areas were sampled in a period of five months during the dry season (May-October). The scheme was repeated in the subsequent year, changing the order of the areas sampled, so that areas sampled at the beginning or end of the dry 
season in 2013 were sampled at the peak of the dry season in 2014, and vice-versa. Since a large part of the corridors becomes flooded during the rainy season, between November and April, the sampling was only possible during the dry season. We baited the camera stations with sardine cans pierced open and fixed on poles or trees placed in front of the cameras. Because of camera malfunction issues and a few theft episodes, the sampling effort varied between stations and consequently between areas. This difference was subsequently taken into account in the analyses.

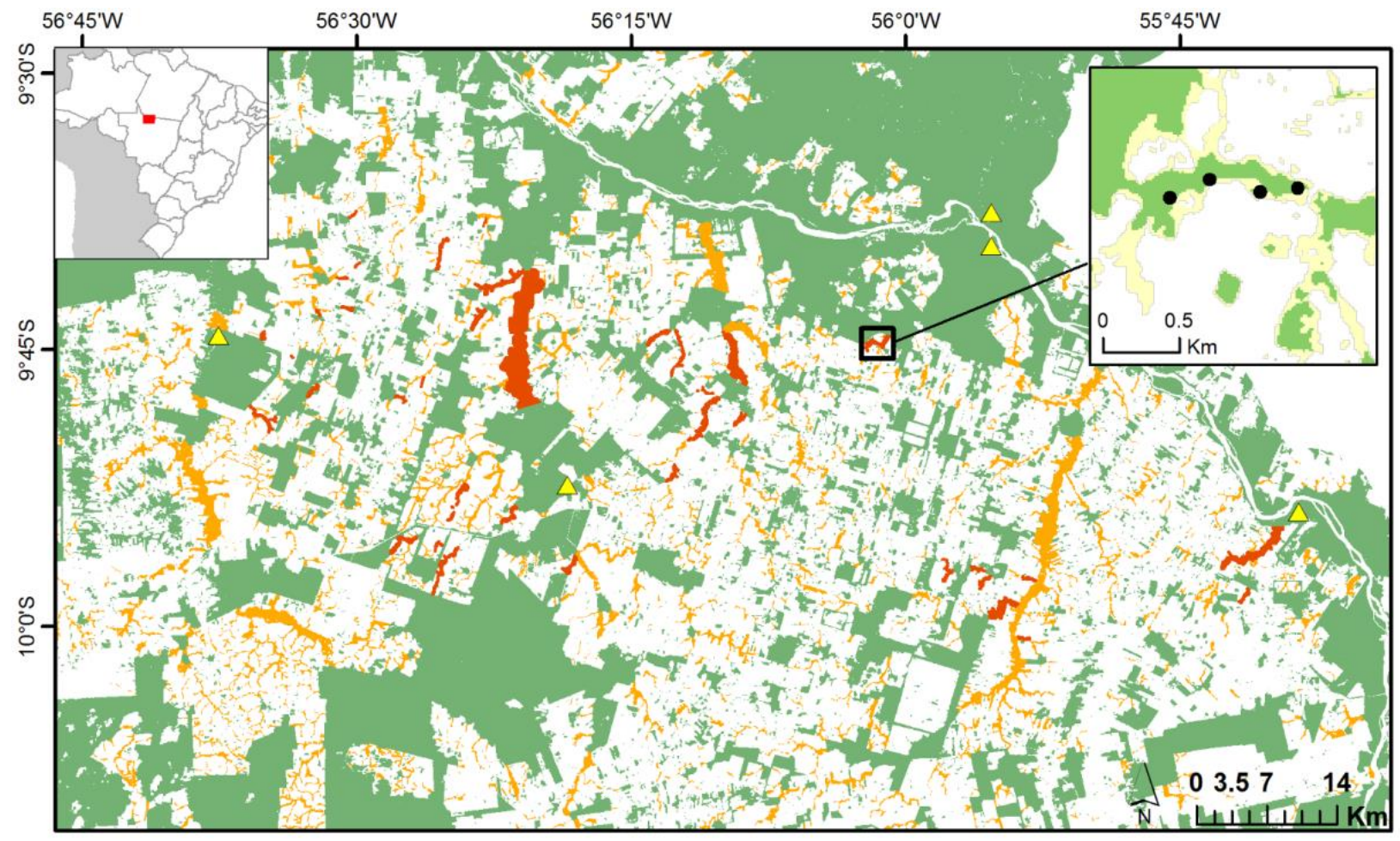

Figure 1. Study area in the state of Mato Grosso, Brazil, showing all the 38 sampled riparian remnants in red and the other identified riparian strips in orange, as well as the pseudo-control riparian forests (yellow triangles). Inset at the top right corner illustrates the 4-5 camera trap stations installed within a riparian corridor, as well as the two different landscape classes 145 obtained by the supervised classification of RapidEye ${ }^{\odot}$ images (mature closed-canopy forest in green, degraded forest in light orange). White background indicates nonforest areas consisting primarily of bovine cattle pastures.

\section{Environmental variables}

A mosaic of RapidEye ${ }^{\odot}$ scenes, with a 15-m resolution from the years 2011-2013, was obtained from the Brazilian Environment Ministry, and used to resolve five distinct landscape 
classes in a supervised classification approach: (1) closed-canopy forest; (2) open-canopy forest (interpreted as degraded or secondary forest); (3) shrubby vegetation; (4) cattle pasture; (5) and eucalyptus/teak plantations. From the classified map we generated four spatial variables, either at the patch or the landscape scale, associated with each riparian corridor: (1) width (m), measured manually at each camera station point (W); (2) non-linear distance to nearest source patch (m), measured manually from each camera station (DIST); (3) source patch size (ha), isolated in the landscape by generating the core areas within source patches (at a distance of $100 \mathrm{~m}$ from the patch edge), and subsequently buffering those core areas at the same distance, thereby producing isolated patches that excluded narrow protrusions and connections (SS); (4) and total forest proportion around the corridor, measured as the total proportion of classes 1 and 2 present within a 1-km buffer around the camera line, generated from the edge of the corridor (FP). Satellite imagery classification was performed using program ENVI 5.0, and the generation and measuring of the spatial variables were conducted in using ArcGIS 10.2.2 (ESRI 2015).

Five in situ metrics describing vegetation quality and preservation status were also obtained at each camera station: (1) tree basal area (BA); (2) understory density (UD); (3) Mauritia flexuosa count (MAU); (4) cattle intrusion (CAT); (5) and proportion of degraded forest (class 2) within a 50-m radius buffer around each camera (DEG). BA was obtained by measuring the distance and diameter at breast height of the nearest tree in a point-quadrat 170 sampling scheme. UD was obtained by counting the number of 10-cm segments entirely visible on a $200-\mathrm{cm}$ pole at distances of $10 \mathrm{~m}$ and $20 \mathrm{~m}$ on either side of the camera station, and then transforming this count into a proportion metric. MAU was obtained by counting the number of Mauritia flexuosa palms from outside the corridor, at a distance of 60 meters from the edge of the corridor, and within an approximate 100-m segment. Mauritia palm aggregations are

175 important features in the forest, since it consists of an entirely different permanently marshy microhabitat, with important food source for many mammal species. CAT was subjectively assessed, by ranking the apparent degree of cattle intrusion within the corridors, from sightings of the animals themselves, signs of vegetation trampling, stream bank erosion, and presence of dungs and tracks. This ranking thus produced five categories: (0) no evidence of cattle trampling;

180 (1) rare; (2) occasional; (3) frequent; and (4) very intensive trampling. DEG was obtained using the classified map described above. 


\section{Occupancy modeling}

We conducted single-season occupancy analyses to model corridor use by each species. In an occupancy analysis, the detection probability (observational process, $p$ ) is modeled first, thus discounting the effect of imperfect detection on the occupancy (or use) probability ( $\Psi$ ), which is the ecological process of interest (MacKenzie et al. 2006). The method assumes closure, which means that occupancy probability does not change during the study period. We considered the two years of study together, since we did not expect the occupancy patterns to change from year to year, and we defined a sampling occasion as a 7-day week, since some of the species were captured at a high rate during the few subsequent days after the first detection, indicating that the records were not independent in such a short time period. Therefore, the capture history consisted of ten sampling occasions (five weeks in each year), although the final week was incomplete. Instead of discarding the last few days of sampling to round the occasions to four full weeks, we considered the total sampling effort as a covariate in the analysis. Occasions on sites without any sampling effort during this final week were modeled as missing observations.

The comparison between riparian forest patches and those embedded within continuous tracts of forest was based on the naïve estimates of site occupancy or observed incidence (proportion of sites occupied), since the imbalance between the number of sites did not allow for the adequate modeling of occupancy patterns between these two groups. We therefore highlight that our estimates of occupancy in continuous forest sites are underestimates of the real patterns. The occupancy within riparian forest strips, however, could be adequately modeled for ten species: the capybara (Hydrochaeris hydrochoerus), the paca (Cuniculus paca), the agouti (Dasyprocta leporina), the common opossum (Didelphis marsupialis), the nine-banded armadillo (Dasypus novemcinctus), the tapir (Tapirus terrestris), the white-lipped peccary

205 (Tayassu pecari), the collared-peccary (Pecari tajacu), the coati (Nasua nasua) and the tayra (Eira barbara).

Two sets of analyses were conducted: the five forest quality variables were modeled together as determinants of occupancy patterns $(\Psi)$ at the scale of each individual camera trap (CT) station $(n=163)$. In order to deal with the spatial dependence at the CT scale, which resulted

210 from the fact that we sampled the community at multiple camera trap stations (4 to 5) within riparian strips, we added the latitude and longitude coordinates of each CT station as covariates 
to filter out this effect. Secondly, the four structural patch- and landscape variables were subsequently modeled at the scale of entire corridors $(n=38)$. In order to model detection probability (p), corridor width (W), understory density (UD) and sampling effort were included as covariates at the CT scale, and corridor width (W) and sampling effort were included as covariates at the corridor scale. However, two species (the tayra and the coati) presented issues of parameter unidentifiability in the forest quality model set. In order to successfully model occupancy patterns for these two species at the CT scale, detection probability structure had to be adapted, by excluding $\mathrm{W}$ and by fixing it at a constant detection, respectively.

We built the candidate model sets including all the additive combinations between the covariates for $\Psi$. Candidate models also included models with constant occupancy and detection probabilities across sites, resulting in a set of 264 candidate models for the quality model set, and 64 models for the landscape structure model set. All variables were standardized, and the landscape variables W, DIST, and SS, as well as the quality variables BA and DEG, were logtransformed to improve linearity. Each set of models was ranked using the Akaike Information Criterion adjusted for small sample sizes (AICc, Burnham \& Anderson 2002). We used modelaveraged estimates of occupancy and detection probabilities, as well as of the regression coefficients and their unconditional standard errors, to assess response patterns to the predictor variables. All analyses were performed using package RMark (Laake 2013) in program R 3.1.2 230 (2014).

\section{Scaling-up exercise}

Modeled estimates of occupancy probabilities, obtained from the model-averaging procedure, were applied to all other 1,915 remnant riparian forests across the study area, defined as the total area of the three municipal counties. Corridors were manually identified, based on the 15-m resolution classified landscape, and between two and five sampling points were placed within each isolated patch in a way that matched our empirical sampling, totaling 5,053 points in the entire landscape. Three variables could be extracted using this procedure, which are easily derived from a remote-sensing approach: (1) the proportion of degraded forest within a 50-m radius buffer around each sampling point (DEG); (2) corridor width at each sampling point (W), which was then averaged across the individual riparian patch; and (3) the proportion of forest within a 1-km buffer around the patch (FP). Geographic coordinates for each sampling point 
were also generated for the cases where the spatial correlation terms were selected as predictors of a species' occupancy probability.

Two scaling-up exercises were conducted: one for the extrapolation of the occupancy models for riparian forest quality at the scale of the sampling points within patches. This procedure was applied to those species that responded to DEG. Another analysis was performed for the occupancy models for patch and landscape structure at the scale of individual patches, applied to those species that responded to W and FP. Model-averaged equations were used, which included the coefficients for all variables selected, as well as estimates of the intercept and

250 the spatial correlation terms whenever they were found to be influential. In the cases where a species responded to other factors that could not be generated using the classified image, such as Mauritia flexuosa aggregations and degree of cattle intrusion, their linear relationships in the general equation were set to zero, so that our scaling-up procedure applies only to the responses of species to degradation that can be inferred by a remote-sensing approach. Occupancy

255 probabilities at each sampling point for the habitat quality exercise were then averaged across all riparian patches.

Finally, a subjective threshold $(\Psi=0.7)$ was applied to the continuous values of occupancy probability predicted, resulting in a binary presence/absence map for each species. This value was considered to be a conservatively high value, since our aim here is to identify those riparian forests that are effectively used by the species, and contribute to landscape connectivity. For the entire landscape, these binary maps were summed up, generating maps describing the pseudo-richness expected in each riparian forest patch. All spatial analyses were conducted in ArcGIS 10.2.2 (ESRI 2015).

Results

During 10,441 sampling days, we obtained 4,459 independent records of 25 species. By far, the most frequently observed species, which also presented the highest incidence in the areas sampled, was the nine-banded armadillo (Dasypus novemcinctus). A little under half the recorded species were rare (less than 30 records) and at least five species were very rarely recorded (less than 10 records) (Figure 2). The observed incidence, also interpreted as the naïve 
occupancy rate, for all species both in riparian forest strips and in continuous forest areas, as well as the modeled occupancy probabilities for the ten species within riparian corridors, are shown in Table 1.

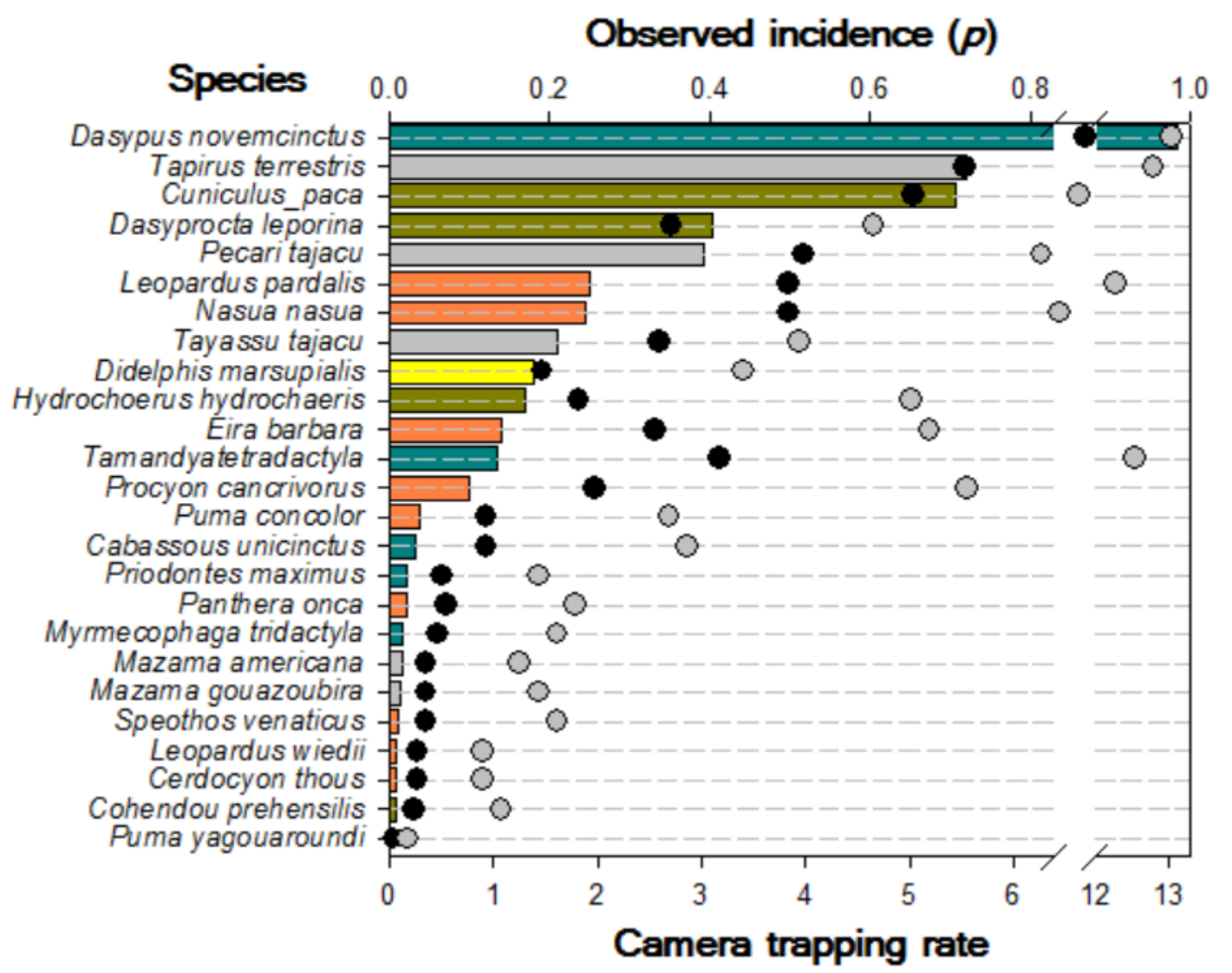

Figure 2. Overall abundance of 25 terrestrial mammal species across all 43 remnant riparian forest corridors sampled in southern Amazonia, as measured by camera-trapping rates (independent photo records per 10,441 camera-trapping nights). Observed incidence refers to the proportion of camera-trap stations (solid circles) and riparian corridors (shaded circles) in which any given species was observed. Horizontal bars are colour-coded in terms of mammalian orders: xenarthrans (blue); ungulates (grey); rodents (green); carnivores (orange); marsupials (yellow). 
Table 1. Naïve occupancy patterns between riparian continuous areas and forest corridors of all species recorded by camera trapping in all sampling stations, as measured by the proportion of sampling areas in which each species was recorded. Estimated occupancy $(\Psi)$ and detection probability (p) ( \pm standard error) are available for the ten species analyzed by occupancy modeling in all riparian forest corridors only.

\begin{tabular}{|c|c|c|c|c|}
\hline \multirow{2}{*}{ Species } & \multicolumn{2}{|c|}{ Naïve occupancy } & \multirow{2}{*}{ Estimated $\Psi$} & \multirow{2}{*}{ Estimated $\mathrm{p}$} \\
\hline & Control & Corridor & & \\
\hline Dasyprocta leporina & 0.56 & 0.32 & $0.26 \pm 0.05$ & $0.29 \pm 0.03$ \\
\hline Eira barbara & 0.52 & 0.29 & $0.98 \pm 0.11$ & $0.06 \pm 0.01$ \\
\hline Nasua nasua & 0.80 & 0.43 & $0.90 \pm 0.11$ & $0.10 \pm 0.01$ \\
\hline Tayassu pecari & 0.76 & 0.24 & $0.26 \pm 0.08$ & $0.13 \pm 0.02$ \\
\hline Cuniculus paca & 0.76 & 0.63 & $0.75 \pm 0.06$ & $0.30 \pm 0.02$ \\
\hline Pecari tajacu & 0.76 & 0.47 & $0.53 \pm 0.06$ & $0.21 \pm 0.02$ \\
\hline Tapirus terrestris & 0.92 & 0.68 & $0.83 \pm 0.06$ & $0.25 \pm 0.02$ \\
\hline Dasypus novemcinctus & 0.4 & 0.93 & $0.96 \pm 0.02$ & $0.47 \pm 0.02$ \\
\hline Didelphis marsupialis & 0.36 & 0.16 & $0.15 \pm 0.04$ & $0.23 \pm 0.03$ \\
\hline Hydrochaeris hydrochoerus & 0.12 & 0.25 & $0.30 \pm 0.05$ & $0.18 \pm 0.02$ \\
\hline Cabassous unicinctus & 0.08 & 0.13 & - & - \\
\hline Priodontes maximus & 0.04 & 0.07 & - & - \\
\hline Tamandua tetradactyla & 0.44 & 0.41 & - & - \\
\hline Myrmecophaga tridactyla & 0.12 & 0.05 & - & - \\
\hline Mazama americana & 0.12 & 0.03 & - & - \\
\hline Mazama sp & 0.2 & 0.02 & - & - \\
\hline Coendou prehensilis & 0.08 & 0.02 & - & - \\
\hline Leopardus pardalis & 0.48 & 0.50 & - & - \\
\hline Leopardus wiedii & 0.04 & 0.03 & - & - \\
\hline Puma concolor & 0.44 & 0.07 & - & - \\
\hline Panthera onca & 0.2 & 0.05 & - & - \\
\hline Puma yagouaroundi & 0 & 0.01 & - & - \\
\hline Speothos venaticus & 0.04 & 0.05 & - & - \\
\hline Cerdocyon thous & 0.2 & 0.01 & - & - \\
\hline Procyon cancrivorus & 0.28 & 0.25 & - & - \\
\hline
\end{tabular}

Detection probabilities were not constant and responded to the one or two of the predictor variables for five species at the CT scale ( $\mathrm{p}($ Width) for T. terrestris; $\mathrm{p}$ (Width + Effort) for $P$. tajacu; $\mathrm{p}$ (Effort) for D. leporina; $\mathrm{p}$ (Effort) for E. barbara; $\mathrm{p}$ (Width + Effort) for C. paca; and 
$\mathrm{p}$ (Width + Effort) for D. novemcinctus), but only two species had non-constant detection probabilities at the corridor scale ( $\mathrm{p}$ (Effort) for T. terrestris; $\mathrm{p}$ (Width) for P. tajacu). Understorey density did not affect detection probability in any case. Detection probabilities were less than 1 in all cases, and the species with the highest detection rates (D. novemcinctus) presented a detection probability of $0.47(\mathrm{SE}=0.02)$. Out of the ten species for which occupancy in riparian corridors was modeled, only two did not present any response patterns to forest quality or landscape structure, according to the regression coefficients obtained in model averaging (SM1 and 2): D. novemcinctus and $H$. hydrochaeris. However, modeling the response of $D$. novemcinctus to landscape and patch structure could not be conducted due to parameter identifiability issues, which was probably caused by its high observed incidence in most riparian strips (lack of variation in the species' response).

The variable that was most often selected as a predictor of occupancy was the proportion of degraded forest around the CT station (DEG), with six species negatively responding to it ( $T$. terrestris, P. tajacu, T. pecari, D. leporina, C. paca and D. marsupialis). Cattle intrusion (CAT) was selected as a predictor of D. leporina occupancy, and Mauritia flexuosa aggregations (MAU) influenced negatively the occupancy probabilities of both C. paca and E. barbara (Figure 3a-i). Five species also responded to the spatial correlation variable (either or both geographic coordinates). Landscape and patch structure influenced the occupancy probabilities of three species: $N$. nasua responded positively to riparian strip width (W), reaching an asymptotic pattern in corridors wider than $220 \mathrm{~m}$ approximately, and the overall remnant forest proportion around each riparian corridor (FP) influenced positively both the peccaries' occupancy probabilities (Figure $3 \mathrm{j}-1$ ). 

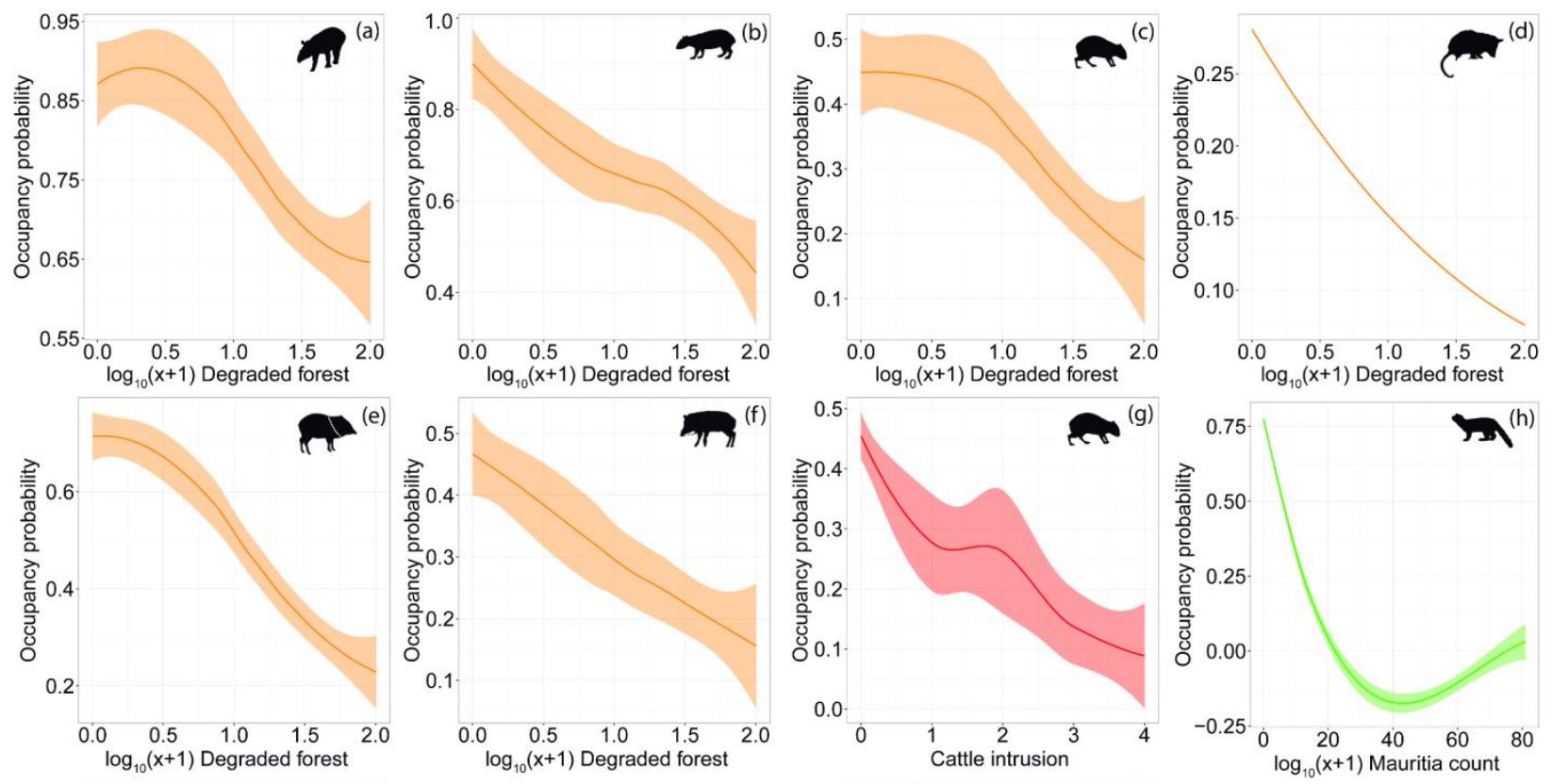

315
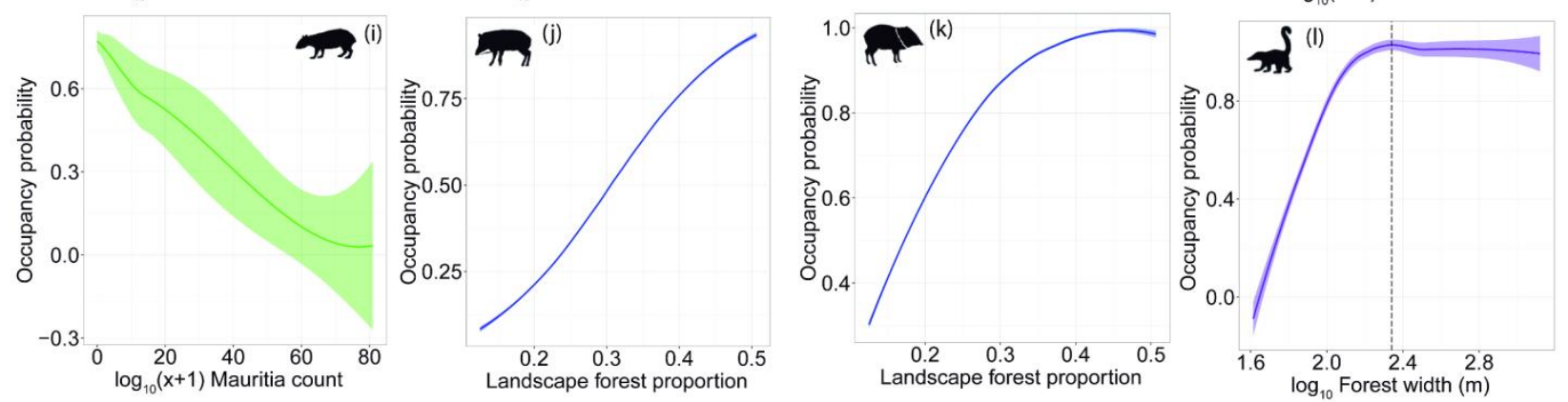

Figure 3. Response curves (and standard errors) between the terrestrial mammal species occupancy probabilities (a- Tapirus terrestris; b and i- Cuniculus paca; c and g- Dasyprocta leporina; d-Didelphis marsupialis; e and k- Pecari tajacu; $\mathrm{f}$ and j-Tayassu pecari; h- Eira barbara; 1-Nasua nasua) and the variables selected (colours group the same variables for the sake of clarity), based on model-averaged regression estimates. Relationships shown are only the ones that have been selected as influential by the model-averaging procedure. Vertical dashed line in (l) indicates the inflection point at which the occupancy probability of $N$. nasua asymptotes.

Across the entire study area, mean proportion of degraded forest within each 50-m buffer around each point was $0.17(\mathrm{SD}=0.24)$. Mean riparian forest width was $153.77 \mathrm{~m}(\mathrm{SD}=93.04 \mathrm{~m})$, ranging from 40.10 to $1131.24 \mathrm{~m}$. Total forest proportion within the 1-km buffers around each riparian strip varied between 0.02 and 0.91 , averaging 0.34 ( $\mathrm{SD}=0.17$ ). Generally, riparian patch suitability based on an occupancy probability threshold of 0.7 was lower when considering habitat quality than structure (Table 2), and higher riparian forest quality was concentrated in the 
southwestern portion of the study region (Figure 4). The lowest suitability was observed for $D$. leporina, for which less than $10 \%$ of riparian patches present a higher occupancy probability higher than 0.7 , and D. marsupialis, due to its overall low occupancy probability ( $\Psi \max =0.28$; Table 2). Patch suitability was also low for T. pecari, for which less than $30 \%$ of riparian patches 335 presented an occupancy probability of over $70 \%$ (Table 2).

Table 2. Mean predicted occupancy probability [and range] across the entire study landscape for each species that responded either to riparian forest quality, measured by the proportion of degraded forest within a 50-m buffer around each sampling point $(n=5,053)$, or landscape and patch structure, measured either by riparian strip width or the total proportion of forest within a $1-\mathrm{km}$ buffer around each patch $(\mathrm{n}=1,915)$. The proportion of riparian patches classified as suitable for use by each species, considering a threshold of $\Psi>0.70$ is also presented.

\begin{tabular}{|c|c|c|c|c|}
\hline \multirow[t]{2}{*}{ Species } & \multicolumn{2}{|c|}{ Quality } & \multicolumn{2}{|c|}{ Structure } \\
\hline & $\Psi$ & Suitable patches & $\Psi$ & Suitable patches \\
\hline Dasyprocta leporina & $0.33[0.01-0.84]$ & 0.06 & - & - \\
\hline Nasua nasua & - & - & $0.81[0.00-1.00]$ & 0.79 \\
\hline Tayassu pecari & $0.35[0.00-0.97]$ & 0.19 & $0.49[0.08-0.99]$ & 0.26 \\
\hline Cuniculus paca & $0.70[0.04-0.98]$ & 0.58 & - & - \\
\hline Pecari tajacu & $0.51[0.01-0.93]$ & 0.31 & $0.81[0.28-0.99]$ & 0.74 \\
\hline Tapirus terrestris & $0.77[0.06-0.99]$ & 0.72 & - & - \\
\hline Didelphis marsupialis & $0.17[0.03-0.28]$ & 0.00 & - & - \\
\hline
\end{tabular}




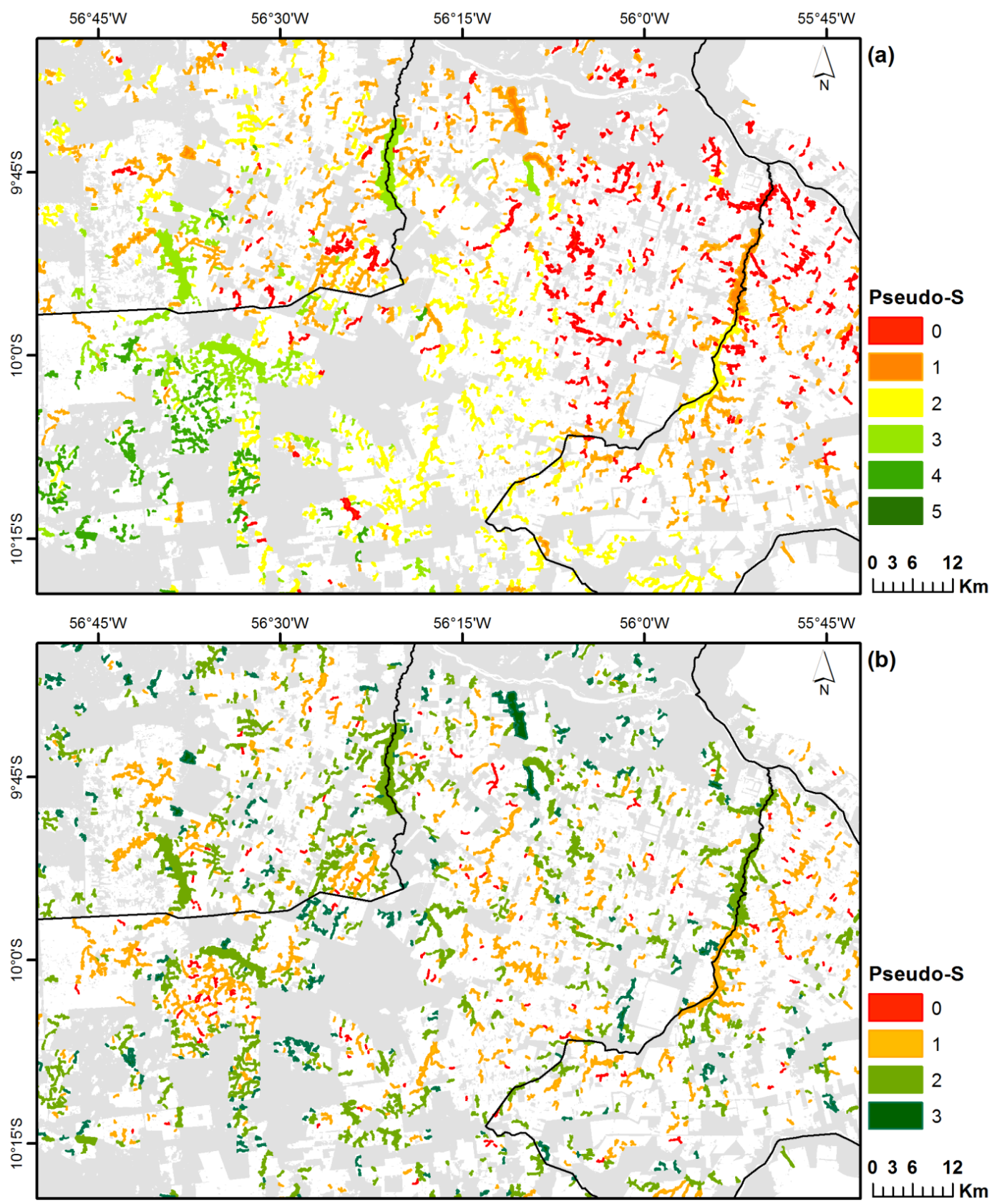

345 Figure 4. Heatmaps indicating the pseudo-richness (pseudo-S), resulting from the sum of binary maps for all species that responded either to (a) riparian forest quality, measured by mean riparian patch forest degradation, or (b) patch and landscape structure, measured either by riparian strip width or the proportion of forest around the patch at a 1-km radius. Binary maps were generated for each species based on the classification of their estimated occupancy probabilities in all riparian patches according to a threshold value of 0.7 . The limits of the three municipal counties comprising the study area are shown as a dark line (Alta Floresta in the centre, Paranaíta to the left, and Carlinda to the right). 


\section{Discussion}

Empirical evidence of habitat use is the basic information necessary for the assessment

355 and planning of suitable and effective conservation measures. Occupancy modeling is a relatively modern tool that permits the estimation of occupancy (or use) probability in the face of imperfect detection, which is almost always the case in nature (MacKenzie et al. 2002). Our analyses have indicated that taking into account detectability differences for each species is crucial, since most species, especially those that are less abundant and/or more sensitive to 360 disturbance, presented non-constant and low detection probabilities. Our observed occupancy rates within continuous riparian areas, therefore, are probably an underestimation of the real patterns at these sites. Nonetheless, naïve occupancy patterns in continuous "pseudo-controls" were systematically greater than those observed in riparian strips, except for two species highly tolerant to the open-habitat matrix - the nine-banded armadillo (D. novemcinctus) and the capybara (H. hydrochaeris) - as well as for a few of the least recorded species - the naked-tale armadillo (Cabassous unicinctus), the giant armadillo (Priodontes maximus), the bush dog (Speothos venaticus), and the eyra cat (Puma yagouaroundi). For these rare species, the low number of records renders patterns inconclusive, but for the first two species, it indicates a high degree of tolerance to the fragmentation process.

The idiosyncrasy found in faunal responses to land use change and human-induced disturbances (Wiens 1989; Beier \& Loe 1992; Taylor et al. 1993; Uezu et al. 2005; Tracey 2006) was also the case in our study. Occupancy probability in response to habitat loss and degradation factors varied between species, without any apparent pattern in accordance to trophic level or body size. For instance, a large species such as the capybara did not respond to habitat quality or structure, while a smaller rodent, the agouti (D. leporina) responded to both habitat degradation and cattle intrusion in the riparian forests. However, an influence of landscape and patch structure on occupancy probability was only observed for three highly social species: the coatis (N. nasua), the white-lipped peccaries (T. pecari) and the collared peccaries (P. tajacu). Species that live in aggregations are expected to forage over greater areas than solitary ones of the same 380 trophic level, since according to the central place theory, they should require a greater area required for supplying food for the group (Recher et al. 1987). This pattern, however, is also related to the species' tolerance to the open-habitat matrix, since the capybaras are another 
highly social species that did not respond to any of the predictors. Especially for forest-strict organisms, riparian forest amount and isolation predict the degree in which these groups have to deal with anthropogenic disturbances, either by having to cross wider areas of the open-habitat while dispersing through the landscape or by being subjected to higher levels of edge-mediated disturbances while moving through the connectors. Social behaviour together with a low tolerance to the anthropogenic matrix, therefore, may be a determinant of how species use narrow forest strips, such as riparian corridors. The interaction between traits and environmental factors should have a better predictive power of a species' sensitivity towards habitat fragmentation (Henle et al. 2004).

All highly forest specific species (which rarely ventures into the anthropogenic matrix), such as the white-lipped peccary (T. pecari), the agouti (D. leporina), the tayra (E. barbara), and the coati (N. nasua), responded to one or more of the occupancy predictors tested, while the two most matrix-tolerant species (D. novemcinctus and H. hydrochaeris) again did not. This is an indication that behavioural tolerance to the human-induced pressures may be a better predictor of their responses to habitat loss and fragmentation than most other eco-morphological traits (Lidicker 1999; Parry et al. 2007). However, contrary to what we would expect, D. marsupialis presented a lower occupancy probability in degraded areas. Didelphids are generally known for being tolerant to anthropogenic disturbances, but it has been suggested that $D$. marsupialis is relatively more sensitive to these effects in comparison with its other congeneric species (Eisenberg \& Redford 1999). Here, we suggest that this species may be affected by other factors that are associated with forest degradation, for instance, the presence of dogs, or some kind of mesopredator release (e.g. the ocelot, which was commonly recorded in riparian corridors).

Mauritia palm aggregations, despite providing a food resource for a number of mammal species, had a negative effect on the occupancy patterns of both the tayra (E. barbara) and the lowland paca (C. paca). We have previously found this counterintuitive result (Chapter 2), and it is related to the fact that the forest formations associated to mauritia palms (veredas) are in a very poor state in the study area. Landowners are required to protect a 50-m buffer zone around 410 these formations, also as a legally prescribed Permanent Protection Area (APP), but since they are on marshy, waterlogged soils, and lack a defined water course from which to measure this protection buffer, most landholders clear the forest around them far beyond the limits legally 
permitted. Especially for the lowland paca this result is important, since mauritia fruits are a well-known food resource for this species (Mendieta Aguilar et al. 2015). The high levels of 415 degradation and forest clearing of the region's veredas are thus not only affecting the potential of these riparian zones for promoting landscape connectivity, but are also possibly affecting the exploration of an abundant forest resource.

Another predictor of habitat quality loss, although undetectable from the remote-sensing images and not correlated to the habitat degradation variable is cattle presence within riparian 420 forests (Chapter 2), which negatively affected agouti occupancy. Cattle access may affect the species' occupancy patterns by the deleterious effect it has on understory vegetation structure, by overgrazing and excessive trampling (Armour et al. 1991; Martin \& McIntyre 2007), possibly also affecting resource availability within heavily intruded habitats. Due to the lack of an effect of understorey density on the species' occupancy probability, we suggest that the latter is a more 425 likely possibility.

One caveat of the present study is that all patches connected by the riparian corridors have been considered similar source patches, where we did not assess differences in baseline occupancy patterns. However, the lack of an effect of source patch size and distance from source on riparian strip occupancy probabilities suggests that this may not have been an issue.

430 Moreover, this pattern corroborates that most studied species manage to disperse through wide areas (such as the social species discussed above) or live within small patches (in the case of small-bodied species such as the agouti), depending on their preservation, structure, and organismal scale of perception (Ricketts 2001). We therefore highlight that our results indicate a role of these riparian forest strips in functioning either as connectors or as home territory, 435 depending on the species.

The proportion of degraded forest around sampling points (camera stations) was the most important determinant of mammal occupancy probability. Over half the species analysed responded negatively to the effects of degradation, as measured by the remote-sensing approach, which captures more severe patterns of degradation reflected in alterations of canopy structure

440 (Gerwing 2002). Addressing this issue is important, as the empirical evidence suggests, but extremely difficult, since the Brazilian Forest Bill makes no requirements concerning habitat quality and integrity in APPs, which can comprise either primary or secondary forests in any 
state of regeneration. In the state of Mato Grosso, where our study took place, most forest remnants are highly exposed to human activities and impacts, such as selective logging, fires, 445 illegal mining, and hunting (Gerwing 2002; Wright et al. 2007; Broadbent et al. 2008). Moreover, recent changes in the Forest Bill (2012) have relaxed the requirements for forest restoration in landholdings previously presenting an environmental deficit. Although not permitting further forest conversion, these changes have stimulated an increase in both forest clearance and degradation throughout the Amazon region (Fonseca et al. 2015). Between 2014 450 and 2015, an increase of 147\% in degradation rates for the entire Amazon region has been estimated, and most of this trend (85\%) was observed in Mato Grosso (Fonseca et al. 2015).

The studied landscape, although presenting a high level of structural connectivity, varies greatly in terms of the potential functional connectivity for the different mammal species. The northeastern portion of the region, mainly the Carlinda county and eastern Alta Floresta, presents 455 the most degraded riparian patches of the entire landscape. The southwestern portion of the Alta Floresta county concentrates the least degraded riparian patches with the greatest potential for mammal species' occupancy, even though a large portion of these patches are relatively narrow. However, both the previous and the new legislation concerning riparian APP width is extremely undemanding, and current requirements vary from $5 \mathrm{~m}$ on each side of all streams in very small

460 landholdings (<100 ha) to 30m in large landholdings (>1,000 ha) on each side of streams narrower than $15 \mathrm{~m}$, which are the great majority of the streams and rivers in the study landscape. In effect, the current legislation simply does not address the ecological requirements of the terrestrial mammal species, if we aim to maintain a landscape mosaic in which the species' have a high probability of surviving, and through which a large number of individuals effectively 465 disperse. The same has been observed for other animal groups, for which the amount of riparian APPs required to maintain a composition and abundance close to the original is far larger than those legally prescribed even by the previous Forest Bill (Laurance \& Gascon 1997; Lees \& Peres 2008; De Fraga et al. 2011; Bueno et al. 2012; Garcia et al. 2013). However, a large portion of the landholders in the region already preserve riparian forests in amount greater than

470 legally required (mean width in the landscape $=150 \mathrm{~m}$ ), and around $80 \%$ of the riparian forests in the region were deemed suitable for the coati (N. nasua), which responded to corridor width. This may derive from the fact that many landholders select riparian zones to set-aside both their required APPs and the landholding's reserva legal, an additional element of protection required 
in the Forest Bill (a proportion of the landholding area to be preserved in natural state, which in

475 the Amazon region is prescribed at 80\%). This strategy may be positive in the maintenance of wider corridors in the landscape, but may increase corridor isolation and decrease habitat complementation (Dunning et al. 1992), since less upland forest is protected within landholdings. This is relevant for some species, such as the white-lipped peccary (T. pecari), for which less than $30 \%$ of riparian forests were suitable due to habitat isolation.

Individual modeling of the effects of habitat structure on occupancy together with the high idiosyncrasy observed may not provide general rules concerning ecological sensitivity to disturbance and functional connectivity to be applied to a wide range of conditions and regions, but allows the identification of species that are more sensitive in the context or landscape under study, as well as those connectors that best promote connectivity. Our approach, by quantifying occupancy patterns according to a conservative threshold, and identifying individual corridors with higher incidence of species, can help in prioritizing protection and restoration efforts. This kind of information is relevant at the scale of entire municipal counties, since it is ultimately the scale at which management actions will be implemented (Gardner et al. 2013).

We have demonstrated that forest degradation is one of the most pervasive and unheeded 490 anthropogenic impacts within riparian strips, affecting their potential in functioning as ecological corridors (see also Harrison 1992; Lees \& Peres 2008). Management such as the implementing of fencing and the protection of riparian patches against fire and illegal mining and logging activities will potentially have a huge influence in restoring and maintaining landscape connectivity for a wide range of terrestrial species, especially in the most heavily degraded parts of the study region. Reinforcing landholding compliance with the current legislation is necessary, but we also suggest that additional management actions consisting of a series of context-relevant incentives and disincentives will be more effective (Godar et al. 2014) for maximizing riparian forest quality and minimizing their isolation, in a coordinated effort to plan a regionally and functionally connected landscape. 


\section{Acknowledgments}

We are grateful to the Brazilian Ministry of Education (CAPES) for funding BZ's PhD studentship. We thank the University of Brasilia for help in the purchase of camera traps, and the University of East Anglia for hosting BZ during a study visit. CNPq provided a research grant (\#306392/2013-5) to RBM. We also thank IdeaWild Organization, Rufford Small Grants Foundation (\#12658-1), and the National Geographic Society/Waitt Grant (\#W314-14), and a CAPES grant to CAP (004-2012) for financial support for the fieldwork in Mato Grosso, Brazil. We are indebted to all landowners for granting access to their properties.

Armour CL, Duff DA, Elmore W. 1991. The effects of livestock grazing on riparian and stream ecosystems. Fisheries 16:7-12.

Beier P, Loe S. 1992. In My Experience: A Checklist for Evaluating Impacts to Wildlife Movement Corridors. Wildlife Society Bulletin 20:434-440.

Beier P, Noss RF. 1998. Do Habitat Corridors Provide Connectivity? Conservation Biology 12:1241-1252.

Bennett AF, Henein K, Merriam G. 1994. Corridor use and the elements of corridor quality: chipmunks and fencerows in a farmland mosaic. Biological Conservation 68:155-165.

Bodmer RE. 1991. Strategies of Seed Dispersal and Seed Predation in Amazonian Ungulates. Biotropica 23:255-261.

Broadbent E, Asner G, Keller M, Knapp D, Oliveira P, Silva J. 2008. Forest fragmentation and edge effects from deforestation and selective logging in the Brazilian Amazon. Biological Conservation 141:1745-1757.

Bueno AS, Bruno RS, Pimentel TP, Sanaiotti TM, Magnusson WE. 2012. The width of riparian habitats for understory birds in an Amazonian forest. Ecological Applications 22:722-734.

Burnham KP, Anderson DR. 2002. Model selection and multimodel inference: a practical informaion-theoretic approach. Springer, New York.

De Fraga R, Lima AP, Magnusson WE. 2011. Mesoscale spatial ecology of a tropical snake assemblage: the width of riparian corridors in central Amazonia. Herpetological Journal 21:51-57.

Dunning JB, Danielson BJ, Pulliam HR. 1992. Ecological Processes That Affect Populations in Complex Landscapes. Oikos 65:169-175. 
Eisenberg J F, Redford KH. 1999. Mammals of the Neotropics. v.3. The University of Chicago Press, Chicago.

Eisenberg JF, Thorington Jr RW. 1973. A preliminary analysis of a neotropical mammal fauna. Biotropica 5:150-161.

ESRI. 2015. ArcGIS Desktop: Release 10.2.2. Environmental Systems Research Institute, Redlands, California.

Fearnside PM. 2005. Deforestation in Brazilian Amazonia : History, Rates, and Consequences. Conservation 19:680-688.

Fonseca A, Justino M, Souza Jr C, Veríssimo A. 2015. Deforestation report for the Brazilian Amazon (July 2015). Imazon, Belém, Brazil.

Garcia LC, dos Santos JS, Matsumoto M, Silva TSF, Padovezi A, Sparovek G, Hobbs RJ. 2013. Restoration challenges and opportunities for increasing landscape connectivity under the new Brazilian forest act. Natureza \& Conservação 11:181-185.

Gardner T a. et al. 2013. A social and ecological assessment of tropical land uses at multiple scales : the Sustainable Amazon Network. Phil Trans R Soc B 368:20120166.

Gascon C, Lovejoy TE, Bierregaard Jr RO, Malcolm JR, Stouffer PC, Vasconcelos HL, Laurance WF, Zimmerman B, Tocher M, Borges S. 1999. Matrix habitat and species richness in tropical forest remnants. Biological Conservation 91:223-229.

Gerwing JJ. 2002. Degradation of forests through logging and fire in the eastern Brazilian Amazon. Forest Ecology and Management 157:131-141.

Godar J, Gardner T a., Tizado EJ, Pacheco P. 2014. Actor-specific contributions to the deforestation slowdown in the Brazilian Amazon. Proceedings of the National Academy of Sciences 111:15591-15596.

Haddad NM. 1999. Corridor Use Predicted from Behaviors at Habitat Boundaries. The American Naturalist 153:215-227.

Haddad NM, Tewksbury JJ. 2005. Low-quality habitat corridors as movement conduits for two butterfly species. Ecological Applications 15:250-257.

560 Harrison RL. 1992. Toward a Theory of Inter-Refuge Corridor Design. Conservation Biology 6:293-295.

Hawes J, Barlow J, Gardner TA, Peres CA. 2008. The value of forest strips for understorey birds in an Amazonian plantation landscape. Biological Conservation 141:2262-2278.

Henle K, Davies KF, Kleyer M, Margules C, Settele J. 2004. Predictors of species sensitivity to fragmentation. Biodiversity and Conservation 13:207-251. 
Hilty JA, Lidicker WZ, Merenlender AM. 2006. Corridor ecology: the science and practice of linking landscapes for biodiversity conservation. Island Press, Washington D.C.

Hobbs RJ. 1992. The Role of Corridors in Conservation: Solution or Bandwagon? Trends in Ecology \& Evolution 7:389-392.

570 Laake JL. 2013. RMark: An R Interface for Analysis of Capture-Recapture Data with MARK. AFSC Processed Rep 2013-01, 25p. Alaska Fish. Sci. Cent., NOAA, Natl. Mar. Fish. Serv., Seattle WA.

Laurance WF, Gascon C. 1997. How to Creatively Fragment a Landscape. Conservation Biology 11:577-579.

575 Lees AC, Peres CA. 2008. Conservation value of remnant riparian forest corridors of varying quality for amazonian birds and mammals. Conservation Biology 22:439-449.

Lidicker WZ. 1999. Response of mammals to habitat edges: a landscape perspective 14:331.

Lindenmayer DB, Nix HA. 1993. Ecological Principles for the Design of Wildlife Corridors. Conservation Biology 7:627-630.

MacArthur RH, Wilson EO. 1967. The theory of island biogeography. Princeton University Press, Princeton.

MacKenzie DI, Nichols JD, Lachman GB, Droege S, Royle JA, Langtimm CA. 2002. Estimating site occupancy rates when detection probabilities are less than one. Ecology 83:2248-2255.

MacKenzie DI, Nichols JD, Royle JA, Pollock KH, Bailey LL, Hines JE. 2006. Occupancy Estimation and Modeling. Page 324. Elsevier, Burlington, MA.

Martin TG, McIntyre S. 2007. Impacts of livestock grazing and tree clearing on birds of woodland and riparian habitats. Conservation Biology 21:504-514.

Mendieta-Aguilar G, Pacheco L, Roldán A. 2015. Dispersión de semillas de Mauritia flexuosa (Arecaceae) por frugívoros terrestres en Laguna Azul, Beni, Bolivia. Acta Amazonica 45:45-56.

Michalski F, Peres CA, Lake IR. 2008. Deforestation dynamics in a fragmented region of southern Amazonia: evaluation and future scenarios. Environmental Conservation 35:93103.

Naiman RJ., Decamps H, Pollock M. 1993. The Role of Riparian Corridors in Maintaining Regional Biodiversity. Ecological Applications 3:209-212.

Noss RF. 1987. Corridors in Real Landscapes: A Reply to Simberloff and Cox. Conservation Biology 1:159-164. 
Parry L, Barlow J, Peres CA. 2007. Large-vertebrate assemblages of primary and secondary forests in the Brazilian Amazon. Journal of Tropical Ecology 23:653-662.

Preston FW. 1962. The canonical distribution of commonness and rarity. Ecology 43:185-215, 410-432.

Prist PR, Michalski F, Metzger JP. 2012. How deforestation pattern in the Amazon influences vertebrate richness and community composition. Landscape Ecology 27:799-812.

R Development Core Team. 2014. R: a language and environmental for statistical computing. R Foundation for Statistical Computing, Vienna, Austria. http://cranr-project.org

Recher HF, Shields J, Kavanagh R, Webb G. 1987. Retaining remnant mature forest for nature conservation at Eden, New South Wales: a review of theory and practice. Pages 177-194 in Saunders DA, Arnold GW, Burbidge AA, Hopkins AJM, editors. Nature Conservation: The Role of Remnants of Native Vegetation. Surrey Beatty, Chipping Norton, Australia.

Saunders DA, Hobbs RJ, Margules CR. 1991. Biological Consequences of Ecosystem Fragmentation: A Review. Conservation Biology 5:18-32.

Sparovek G, Barretto AGDOP, Matsumoto M, Berndes G. 2015. Effects of governance on availability of land for agriculture and conservation in Brazil. Environmental Science and Technology 49:10285-10293.

615 Taylor PD, Fahrig L, Henein K, Merriam G. 1993. Connectivity Is a Vital Element of Landscape Structure. Oikos 68:571-573.

Tracey JA. 2006. Individual-based modeling as a tool for conserving connectivity. Pages 343368 in Crooks KR, Sanjayan M, editors. Connectivity conservation. Cambridge University Press, Cambridge, UK.

Tubelis DP, Lindenmayer DB, Cowling A. 2007. The peninsula effect on bird species in native eucalypt forests in a wood production landscape in Australia. Journal of Zoology 271:1118.

Uezu A, Metzger JP, Vielliard JME. 2005. Effects of structural and functional connectivity and patch size on the abundance of seven Atlantic Forest bird species. Biological Conservation 123:507-519.

Umetsu F, Paul Metzger J, Pardini R. 2008. Importance of estimating matrix quality for modeling species distribution in complex tropical landscapes: a test with Atlantic forest small mammals. Ecography 31:359-370.

Wiens JA. 1989. Spatial Scaling in Ecology. Functional Ecology 3:385-397.

Wiens JA, Stenseth NC, Van Horne B, Ims RA. 1993. Ecological Mechanisms and Landscape Ecology. Oikos 66:369-380. 
Wright SJ, Stoner KE, Beckman N, Corlett RT, Dirzo R, Muller-Landau HC, Nuñez-Iturri G, Peres CA, Wang BC. 2007. The Plight of Large Animals in Tropical Forests and the Consequences for Plant Regeneration. Biotropica 39:289-291. 


\section{Supplementary Material}
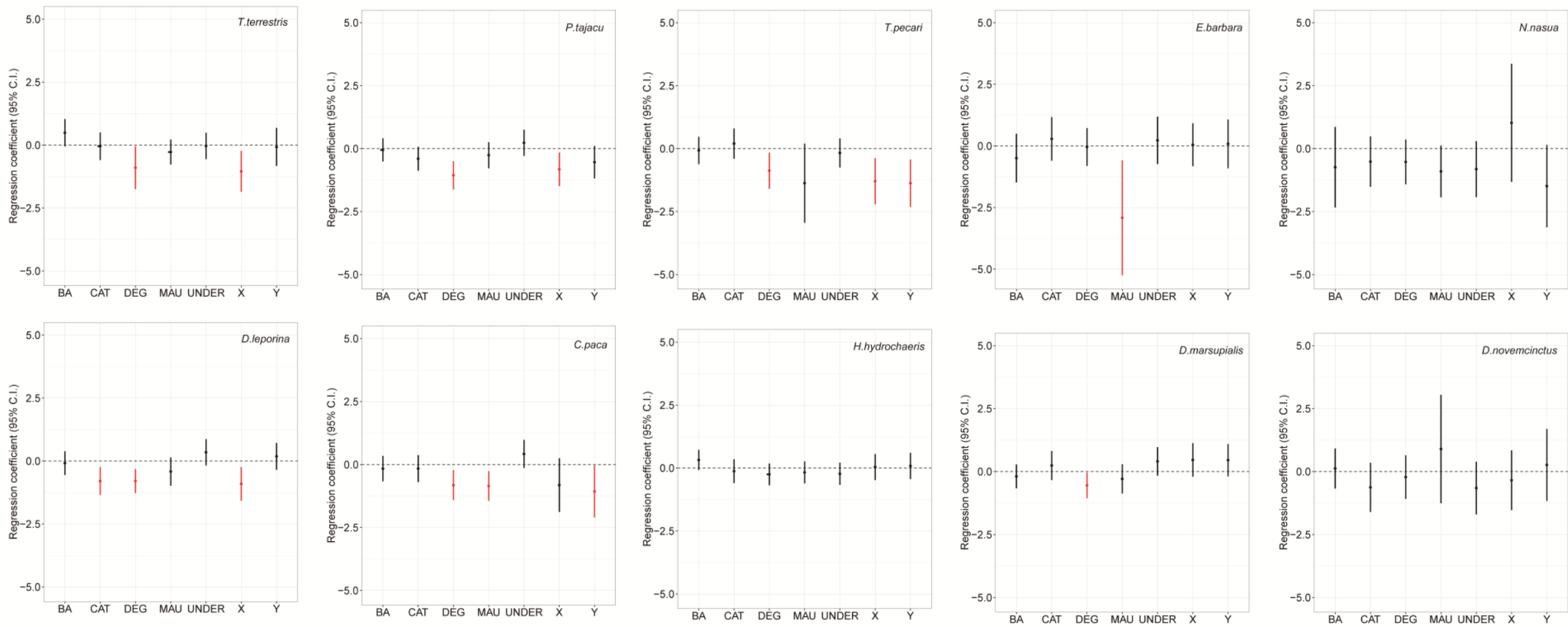

SM1. Regression coefficients (and 95\% confidence intervals) for all variables included in the global models for the effect of riparian forest quality on occupancy probabilities of the analysed mammal species (Tapirus terrestris, Pecari tajacu, Tayassu pecari, Eyra barbara, Nasua nasua, Dasyprocta leporina, Cuniculus paca, Hydrochoerus hydrochaeris, Didelphis marsupialis, and Dasypus novemcinctus), and obtained by model averaging. Variables describing forest quality include: BA - tree basal area $\left(\mathrm{m}^{2} / \mathrm{ha}\right)$; CAT - degree of cattle intrusion (0-4); DEG proportion of degraded forest within a 50-m buffer around each sampling site (camera trap station); MAU - Mauritia flexuosa abundance at each sampling site; UNDER - understorey density; X and Y - geographic coordinates of each sampling site, included as spatial autocorrelation covariates. 

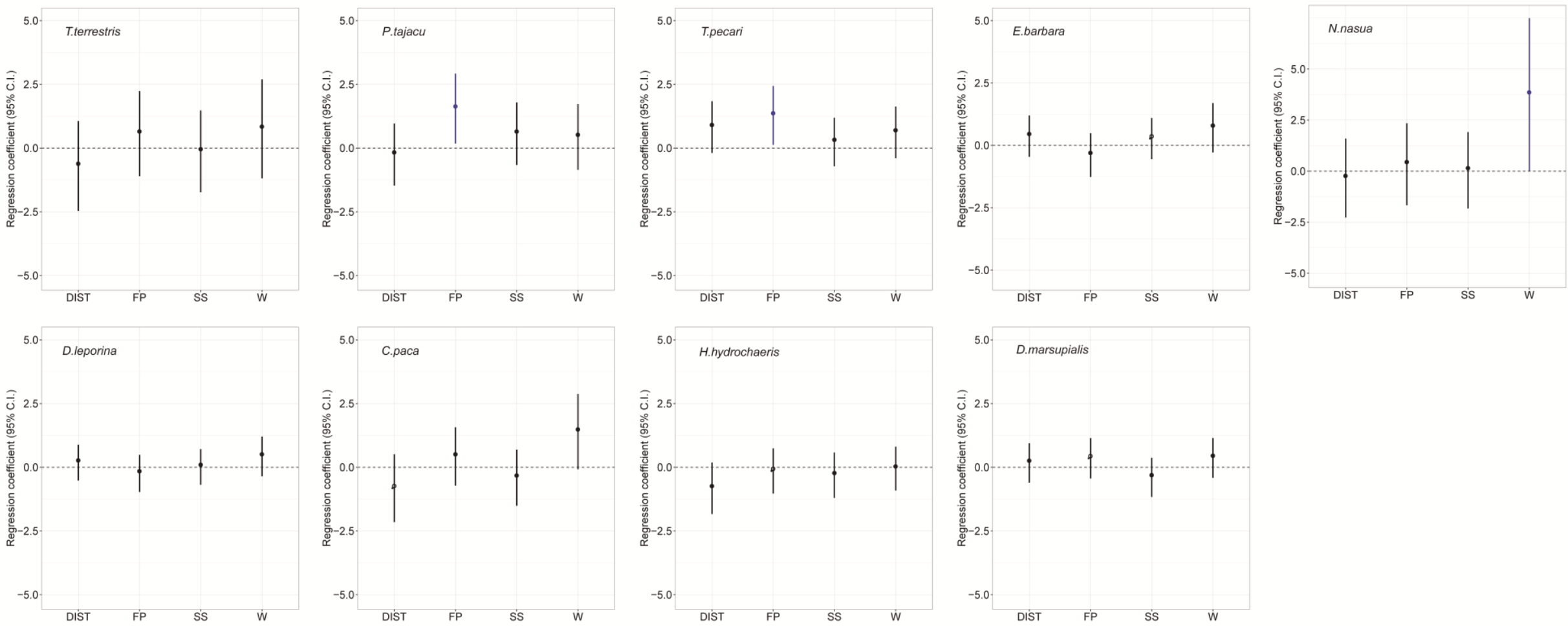

SM2. Regression coefficients (and 95\% confidence intervals) for all variables included in the global models for the effect of riparian patch and landscape structure on occupancy probabilities of the analysed mammal species (Tapirus terrestris, Pecari tajacu, Tayassu pecari, Eyra barbara, Nasua nasua, Dasyprocta leporina, Cuniculus paca, Hydrochoerus hydrochaeris, Didelphis marsupialis, and Dasypus novemcinctus), and obtained by model averaging. Variables describing patch and landscape structure include: DIST - non-linear distance to

650 the nearest source patch (m); FP - total forest proportion within a 1-km buffer around the riparian patch; SS - nearest source patch size (ha); and $\mathrm{W}$ - mean riparian strip width $(\mathrm{m})$. 


\title{
Capítulo 4
}

Drivers of headwater and riparian forest loss and degradation in a highly fragmented landscape in the Southern Amazon

5

\begin{abstract}
In the Brazilian Amazon, a large part of the remaining natural vegetation is kept within private lands. A thorough understanding of the local-scale drivers of deforestation and forest degradation requires the identification of context-dependent practices and pressures in a region. In our study, we aimed at examining the spatial drivers that determine the amount and quality of riparian and headwater forests within landholdings in a highly fragmented landscape in the Southern Amazon. We also tested how these spatial determinants influence the quality of riparian forests at the scale of individual forest patches, while describing the patterns of forest degradation in situ. We built generalized linear models to assess the influence of landholding size, distance to roads and to town on forest amount and forest quality of both headwater and riparian zones within landholdings, and we described landholder compliance rates according to both the previous and the current legislation. We also modeled the quality of 38 sampled individual riparian forests according to the same spatial variables with the addition of: 1) degree of cattle intrusion within the forest and 2) forest width. We finally evaluated the linear relationships among the local forest structure variables in order to elucidate patterns of forest degradation. Forest loss and degradation are commonly associated, but forest degradation can also respond independently to the some of the same drivers. Headwater forests were generally in worse conditions than riparian forests, and both large and small landholders tended to clear their headwater patches beyond legal requirements. Distance to roads also influenced general forest amount and quality, and distance to town affected all variables, except headwater forest quality. Degradation was greater in narrower riparian forests, and the structural changes detected within riparian forests included the effect of cattle intrusion within the forest, which affects the understory, and the decrease in forest profile height and homogeneity.
\end{abstract}

Keywords: compliance, deforestation, environmental legislation, forest quality, private landholdings 
Introduction

Large part of the focus of conservation biology has historically been on the selection and setting-aside of large areas for the implementation of reserves, but most of a region's natural vegetation cover will be frequently located within private properties (Perfecto \& Vandermeer 2008; Gardner et al. 2009). In Brazil, more than half of the remaining natural vegetation is currently kept within $\sim 5.5$ million private lands (Ferreira et al. 2012). In these areas lie the greatest opportunities for the management of natural features aiming at the preservation of ecosystem services as well as of biodiversity, and most of the restoration efforts will concentrate on remnant habitat patches embedded in an anthropogenic matrix and subject to severe humaninduced pressures. Therefore, the discussion of how best to manage remnants or restore the natural cover will need to take into account context-dependent practices and pressures in a region, in order to understand the local-scale drivers of deforestation and forest degradation, while care must be taken in extrapolating the patterns observed in a region to another (Gardner et al. 2009).

A large part of the southern portion of Brazilian Amazonia has undergone severe deforestation since the late 1970's, creating an extensive fragmented landscape with varying degrees of forest cover (Michalski et al. 2008; Soler et al. 2009). The greatest part of the landscape however is still above the threshold level (30\% of remnant native vegetation) where opportunities to manage forest remnants for the sake of biodiversity and natural habitats are most feasible and desirable (Banks-Leite et al. 2014). This region, located in what is known as a deforestation frontier, was occupied responding to different pressures and incentives over time, and is now mostly covered by private landholdings of varying sizes, while reserves aimed specifically at ecological conservation are scarce (Michalski et al. 2010a). Agricultural activities and ranching are the main land-use activities that drive deforestation in the region, but the contribution of different actors - namely small and large landholders - to the process is dependent on regional historical and socioeconomic contexts (Geist \& Lambin 2002). At the same time, quantifying and understanding the determinants of deforestation operating at the scale of individual properties is critical, because that is the scale at which policy actions will ultimately be implemented (Aguiar et al. 2007; Gardner et al. 2013).

Recent politically motivated changes in the Brazilian environmental legislation have decreased the requirements for the restoration of native vegetation set-asides in private 
properties, and pardoned a large part of past illegal deforestation, despite vehement criticism from the scientific community (Lewinsohn 2010; Metzger et al. 2010; Michalski et al. 2010b). Areas of Permanent Protection (APP) are such required set-asides prescribed in the Brazilian Forest Code (Brasil 2012). These include riparian and headwater zones as well as steep terrains, hilltops, dune zones, among other important and fragile landscape features. In the Amazon region, the most ubiquitous of these APPs are riparian and headwater zones. Their primary goal is to maintain the functioning of the hydrological cycle, although their importance in the maintenance of other ecosystem services, such as soil stabilization and promoting connectivity for biodiversity is also mentioned in the legislation, and the importance of riparian habitats for the biodiversity is widely recognized in the scientific community (Quigley \& Crawshaw Jr. 1992; Niman et al. 1993; Lima \& Gascon 1999; Uezu et al. 2005; Keuroghlian \& Eaton 2008; Lees \& Peres 2008; Martensen et al. 2008; Maltchik et al. 2008). As ecologists and conservationists, our understanding of the local context and drivers of land use change will be valuable to counter-act the negative effects of these policy changes.

Moreover, the conservation of natural habitats has always focused on the loss and fragmentation of the remaining areas, while habitat degradation has been extensively overlooked (Ferreira et al. 2012). Even the Brazilian Forest Code (FC), that defines the legal requirements

85 for forest maintenance and preservation within private land, hardly mentions habitat degradation. A lot of work has been done focusing on the contribution of small and large landholdings on forest loss (e.g. Aldrich et al. 2006; Aguiar et al. 2007; Michalski et al. 2010; Gardner et al. 2013), while little effort has been done to assess their contribution to forest degradation (Godar et al. 2014). Conservation actions planned under the UN/REDD+ (United Nations/Reducing Emissions from Deforestation and Forest Degradation) framework will require a more thorough understanding of the drivers of forest quality erosion as well as forest loss (Gardner et al. 2012), and the characterization of the patterns of degradation at a high spatial resolution (Foley et al. 2007).

Therefore, the goals of this study were threefold. First, at the scale of an entire municipal county, we aimed at describing the state (amount and quality of the forest) of the riparian and headwater areas of permanent protection (APP) within landholdings of varying sizes in a highly fragmented landscape in the Southern Amazon, while assessing which spatial drivers determine their state of preservation. We hypothesized that forest amount and quality would be influenced 
by: 1) the size of the landholding in which they are located, because large landholders are 100 generally found to comply with the law more often than small ones; 2) the distance to the municipality's main town, which is related to the intensity of anthropogenic urban pressure exerted on these forest patches (with a population of over 50,000 inhabitants, IBGE/ SIDRA 2015); and 3) the distance to main and secondary roads, which may be related to the age of the deforestation, and areas that have undergone deforestation in earlier stages of the region's colonization were more heavily cleared since they were acting in an era of governmental incentives, and environmental preservation was not often a concern. Secondly, we tested how landscape and management determinants influence the quality of riparian forests at the scale of individual forest patches. At this more local scale, the same drivers described above were hypothesized to affect forest quality, with the addition of riparian forest width, and the degree of cattle intrusion within the remnant, which is a pervasive source of disturbance in riparian forest patches. Finally, we aimed at elucidating what changes in the forest structural quality result from the degradation process, by exploring the relationships between the vegetation structural variables measured in situ.

115 Methods

\section{Study area}

The Alta Floresta municipal county, located in the North of the state of Mato Grosso (0953'S, 56 $\left.28^{\circ} \mathrm{W}\right)$, encompasses a highly altered landscape spanning 894,605 hectares, which has been severely deforested due to a governmental incentive to the establishment of bovine 120 cattle farms in the region mainly during the 1980s and 1990s. The county together with its neighbors now represent one of the most altered regions of the Amazon rainforest, and considered part of the Brazilian 'arc of deforestation'. Currently, the great majority of the landscape is covered by cattle farms, forming a relatively homogenous pasture matrix in which forest fragments, riparian forests, and headwater patches of varying sizes and quality are

125 embedded (Michalski et al. 2008). Alta Floresta alone harbors a herd size of 838,700 distributed in more than 4,000 landholdings of varying size. Because only the information on the location of headwaters as well as the map of landholdings for Alta Floresta was available, the analyses were conducted for this county alone. However, for the description of internal structural variables 
within riparian forest strips, we obtained data from 38 riparian corridors located in Alta Floresta as well as in both neighboring counties: Paranaíta, to the west $\left(09^{\circ} 40^{\prime} \mathrm{S}, 56^{\circ} 28^{\prime} \mathrm{W}\right)$, and Carlinda, to the east $\left(09^{\circ} 58^{\prime} \mathrm{S}, 5^{\circ} 49^{\prime} \mathrm{W}\right)$. These together comprise $1,620,000$ ha, and present circa $53 \%$ of remaining forest vegetation. Prior to the beginning of the deforestation process, all three counties were formed by similar baseline forests.

\section{Compliance rates}

We quantified the amount of APP closed-canopy and degraded forests in each landholding, and presented the compliance rate according to both the previous and the current Forest Code (FC). The previous FC required the maintenance of a 30-m patch of forest along each side of rivers and streams narrower than $10 \mathrm{~m}$. The new requirements for these narrow streams, however, depend on the landholding size class as described in the current FC: Class 1 includes landholdings smaller than 100 hectares, which are required to protect $5 \mathrm{~m}$ of forest on either stream bank, independent on river width; Class 2 includes landholdings with areas between 100 and 200 hectares, which are required to keep 8m of forest on each bank; Class 3 includes landholdings with areas between 200 and 400 hectares, which are required to maintain

$14510 \mathrm{~m}$ of forest on each bank; and Class 4 includes large landholdings with more than 400 hectares, which are required to protect $20 \mathrm{~m}$ of forest on either side of rivers and streams of any width. Wider rivers had different forest width requirements, but since the great majority of the region's river system is formed by narrow streams, we only analyzed the state of preservation of these small streams and rivers. For the protection of headwaters, the previous FC required a 50$\mathrm{m}$ radius patch around each headwater, but now only a $15-\mathrm{m}$ buffer of forest must be protected. The current FC does not allow for new deforestation above the thresholds defined in the previous FC, but largely pardoned deforestation actions that occurred before July 2008 by dropping restoration requirements. Because the study region has undergone deforestation mostly during the 1980s and 1990s, we considered that this general amnesty for past clear-cutting of the forest 155 applied to our landscape.

\section{Landscape variables}

The study landscape was mapped in a supervised classification of 15m-resolution RapidEye scenes, dated between 2011 and 2012. The classification was performed using the 
maximum-likelihood algorithm, and was validated with independent ground-truthed points. We were able to resolve five landscape classes: 1) closed-canopy forest; 2) pasture matrix; 3) degraded or secondary forest; 4) low shrubby vegetation; 5) and eucalyptus and teak plantations. In the analyses, we focused on the first three classes, for they were the predominant classes in the landscape, and are involved in the process of large-scale deforestation and forest quality erosion, in which we were interested. All remote sensing procedures were conducted in ENVI 4.7 (Exelis Visual Information Solutions, Boulder, Colorado).

We obtained the maps of headwaters and rivers in Alta Floresta from a non-governmental organization based in the county - ICV (Instituto Centro de Vida, Alta Floresta). These maps were used to quantify the state of preservation of the headwater and riparian forest patches, measured as the amount of the three landscape classes within a $150-\mathrm{m}$ buffer around them (Figure 1B). The choice of this distance criterion allowed us to assess the state of preservation of the remnant patches in a more general context, since we consider even the past FC requirements to be insufficient from an ecological perspective. Also, a larger buffer will be less sensitive to small-scale location errors and to differences in the shape of the remnant patches.

A map of the main and secondary roads in Alta Floresta was obtained from the ICV. We also obtained the map of 3,366 landholdings for the county of Alta Floresta from the Mato Grosso state environmental agency, the municipal environmental agency, and from private real estate companies. Their sizes varied between 5 ha (very small settlements) and 16,000 ha (very large private landholdings), and they cover $65 \%$ of the county area (Figure 1A). The maps of 180 headwaters and rivers were crossed with those of the landholdings to calculate their state of preservation in each rural property. The samples considered were not the individual buffers, but the individual landholdings, since most riparian forests are connected, and it is difficult and arbitrary to isolate individual riparian patches. One caveat in our analysis is the effect of the consolidation process that has in some cases taken place, in which several small landholdings are 185 purchased and 'consolidated' as a large landholding. In these cases, patterns of deforestation caused by one group could be analyzed as caused by another. We observed one such case, by identifying a conflict between the databases, and thus decided to consider the older 'unconsolidated' properties in the analyses. 


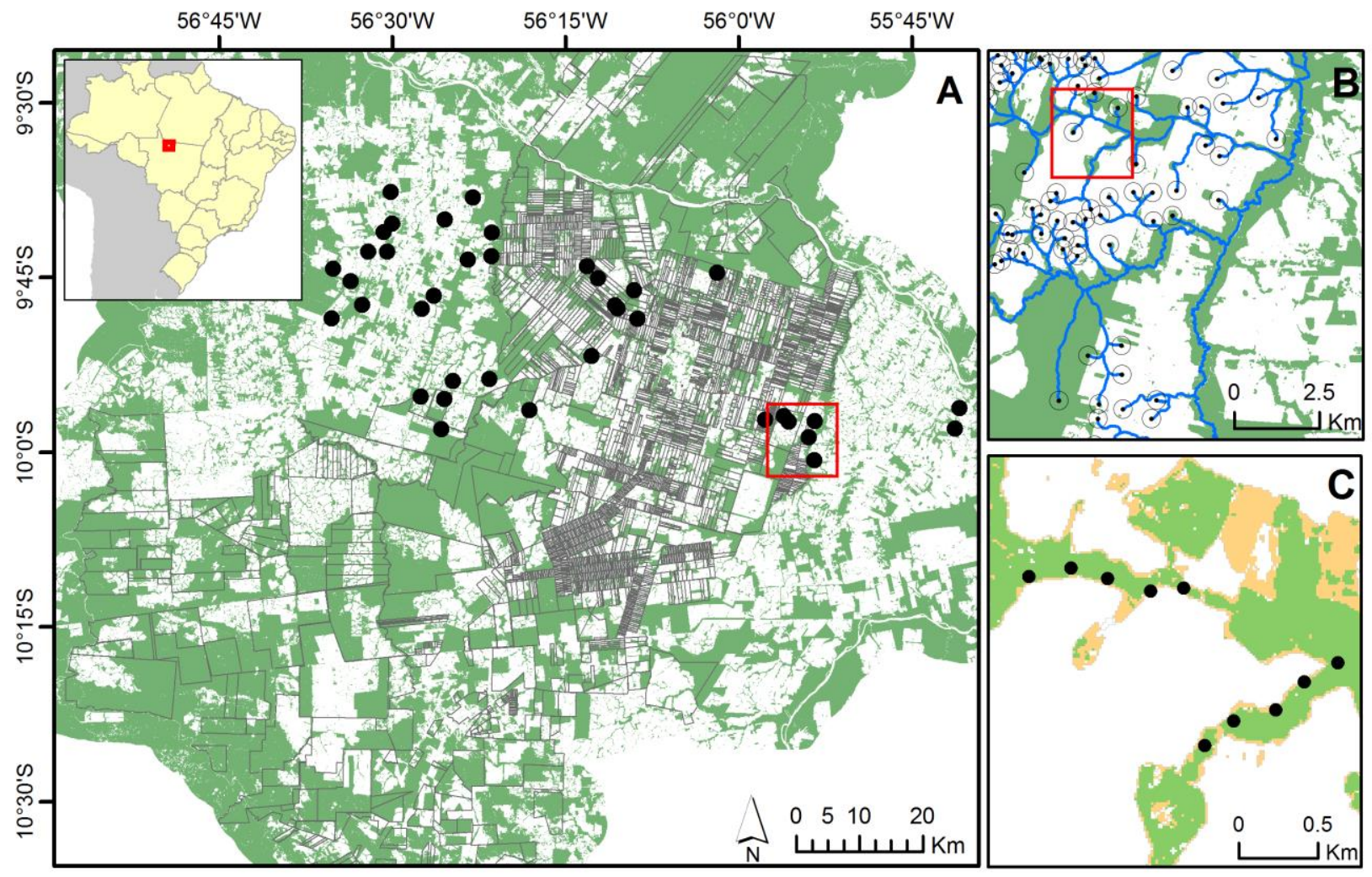

Figure 1. Cattle-ranching landholdings in Alta Floresta, state of Mato Grosso, Brazil (A), headwater and riparian features (B), and selected sites for sampling the internal structural variables (points in A and C). Different colors in $\mathrm{C}$ represent the classes obtained by the supervised classification of RapidEye images (closed-canopy forest in green, degraded forest in light orange, and pasture matrix in white).

\section{Forest quality variables}

We collected in situ data on 38 riparian forests across the three neighboring municipal counties, during the dry seasons of 2013 and 2014. Within each riparian forest selected, we measured internal and external landscape variables in four or five sites spaced at least $250 \mathrm{~m}$ apart (Figure 1C). We obtained the following variables: 1) tree basal area $\left.\left(\mathrm{m}^{2} / \mathrm{ha}\right) ; 2\right)$ canopy density; 3) understory density; 4) an ordinated variable describing the degree of cattle intrusion in the forest based on direct observations of cattle tracks within a 30-m radial area. (0- no evidence of cattle intrusion; 1- rare cattle intrusion; 2- occasional cattle intrusion; 3- frequent cattle intrusion; and 4- very frequent cattle intrusion); 5) vertical profile pixel count and variation coefficient, based on digital photographs of a perpendicular 100-m segment, taken at a distance 
of $60 \mathrm{~m}$ from the forest's edge and centered at the sampling site; and 6) Mauritia flexuosa palms count.

The first three variables were measured in a point-quadrat sampling design. In each

210 selected site within a riparian forest, we placed four points $20 \mathrm{~m}$ apart, where we divided a 10-m radius circle into four quadrats. In each of the quadrats, we searched and measured the distance to and the diameter at breast height of the nearest tree (only considering trees with diameters greater than $10 \mathrm{~cm}$ ). At each central point, we estimated understory density by counting the proportion of visible $10-\mathrm{cm}$ segments of a $200-\mathrm{cm}$ long pole at a distance of $10 \mathrm{~m}$. Also at the central point, we estimated canopy density, by obtaining vertical canopy photographs using a digital camera with a FishEye $60 \mathrm{~mm}$ lens, and subsequently counting the proportion of dark pixels in each image. In a single forest site, we thus measured 16 trees (64 or 80 basal area measures per riparian forest, depending on whether four or five sites were sampled in the forest patch), and obtained four understory density measurements and canopy photographs (16 or 20 measurements and images per forest patch).

The vertical profile measurements allowed us to quantify and compare the degree of structural degradation visible from outside the forest strips, which includes first the death of larger and taller trees, causing a pronounced variation in the vegetation profile (Figure 2B), and lastly, after a longer period of tree mortality, a generalized decrease in forest height (Figure 2C).

225 Both the vertical profiles and the canopy images were classified into binary images using the software ImageJ 1.45. The overall pixel count and the coefficient of variation between all columns's dark pixel count in the profile images were considered as measures of profile health. These counts were conducted in the software R 3.1.2 (R Development Team 2014). Mauritia palms were also counted from outside the forest patch, from the same spot where the vertical 230 profiles images were taken. 

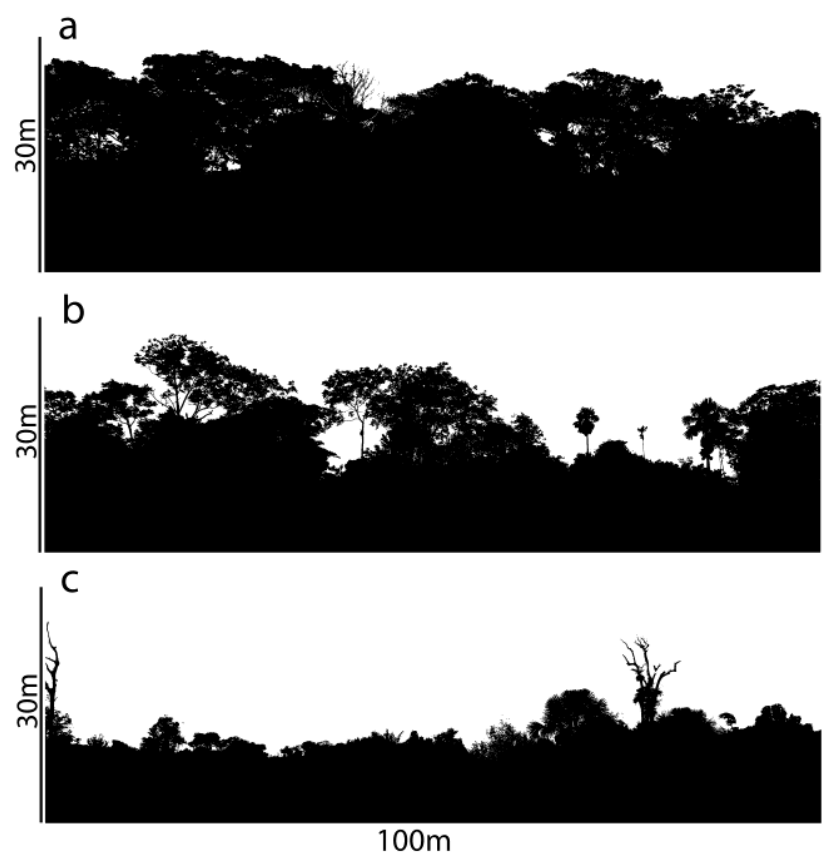

Figure 2. Binary classification of digital vertical profile images taken at a $60-\mathrm{m}$ distance from the forest edge, showing a gradient of riparian forest quality, from a better preserved (A), an intermediate quality (B) to a highly degraded (C) profile.

Finally, the remote-sensing approach allowed us to obtain information on 1) forest width, measured manually as the length of the transversal section of the forest at the sampling point, and 2) the proportion of the closed-canopy forest around each sampling site, which was calculated within a 50-m buffer centered at each sample site, in order to be equivalent to the 100$\mathrm{m}$ segment represented by the vertical profile photographs.

\section{Analyses}

At the scale of the entire municipal county, we built generalized linear models to assess the influence of the landscape variables on forest amount (the proportion of closed-canopy plus 245 degraded forest) and forest quality (the proportion of closed-canopy forest only) of both headwater and riparian zones within landholdings. The variables modeled to influence total forest amount were: 1) the size of the landholding; 2) the distance to Alta Floresta; and 3) the distance to main and secondary roads. The variables we hypothesized to influence the quality of riparian and headwater forests were the same as described above, with the addition of the proportion of the landholding which was covered by forest, as a proxy to the size of the remnant 
patches, to account for the fact that smaller patches are more affected by edge effects than larger ones.

Thus a total of four global models were built, using a binomial distribution of the dependent variables. All included independent variables were standardized and tested for 255 colinearity. We did not detect a high correlation between them (Pearson's $\mathrm{R}<0.6$ ). Landholding size and distance to roads were log-transformed to better linearize their distributions. We detected a spatial autocorrelation in the global model's residuals (using Moran's I), and therefore performed a selection of spatial eigenvector filters to include these in the global models to be reanalyzed (Diniz-Filho \& Bini 2005). The general fit of the global models was assessed by a visual inspection of the residuals. We also tested for, and did not detect, overdispersion in the data. We analyzed models that contained all additive combinations of the hypothesized variables, and performed a model selection procedure based on the Akaike Information Criterion (AIC) (Burnham and Anderson 2002). We used a model averaging procedure to extract the estimated beta-coefficients and confidence intervals for each variable.

In order to assess the influence of the landscape drivers on the quality of riparian forests at a more local scale, we conducted a generalized linear mixed-effects model analysis considering the 38 sampled riparian patches. We modeled our dependent variable as the closedcanopy pixel count within the 50-m buffer in a Poisson distribution weighed by the total forest pixel count. The independent variables included in the model included: 1) landholding size class

270 (since we did not have the map of all the landholdings in which we sampled); 2) distance to nearest town (in this case including the towns of Paranaíta and Carlinda as well); 3) distance to the nearest primary or secondary road; 4) the ordinated variable measuring the degree of cattle inclusion; and 5) forest width. Distance to roads and width were both log-transformed prior to standardization. We included the individual riparian forest as the random factor, as well as an 275 observation-level random effect factor, as a way of dealing with the overdispersion detected in the data (Harrison 2014). Additive combinations of the global model were generated and selected by the Akaike Information Criterion (AIC) (Burnham and Anderson 2002).

Finally, we conducted exploratory analyses of the in situ structural quality variables for the riparian forests. We evaluated the linear relationships among the local variables in order to 280 elucidate patterns of forest degradation in the region. We also related the local structural variables to the proportion of closed-canopy forest within the 50-m buffer described above, in 
order to assess which changes in vegetation structure mediate (and are captured by) the remotesensed forest degradation.

All analyses were conducted in R 3.1.2 (R Development Team 2014), except for the 285 generation and selection of the spatial filters, which we performed using SAM 4.0 (Rangel et al. 2010).

Results

We obtained information on 12,277 hectares of headwater forests within 2,034 cattle 290 farms as well as 95,236 hectares of riparian forests within 2,958 farms in Alta Floresta. The proportion of forest within the APP buffers is presented in Figure 3. Landholdings that correctly maintain headwater forests represent $27.09 \%$ of the total considering the previous $50-\mathrm{m}$ requirement, and $44.79 \%$ considering the $15 \mathrm{~m}$ requirement, but compliance rates vary with farm size (Table 1). In the case of riparian forests, considering the requirements for each landholding size class, we estimated that $84.89 \%$ of the total cattle farms comply with the new legislation. However, under the previous 30-m requirement, independent on landholding size, the compliance rate was much lower $(58.18 \%)$, with smaller farm properties accounting for most of this deficit (Table 1).
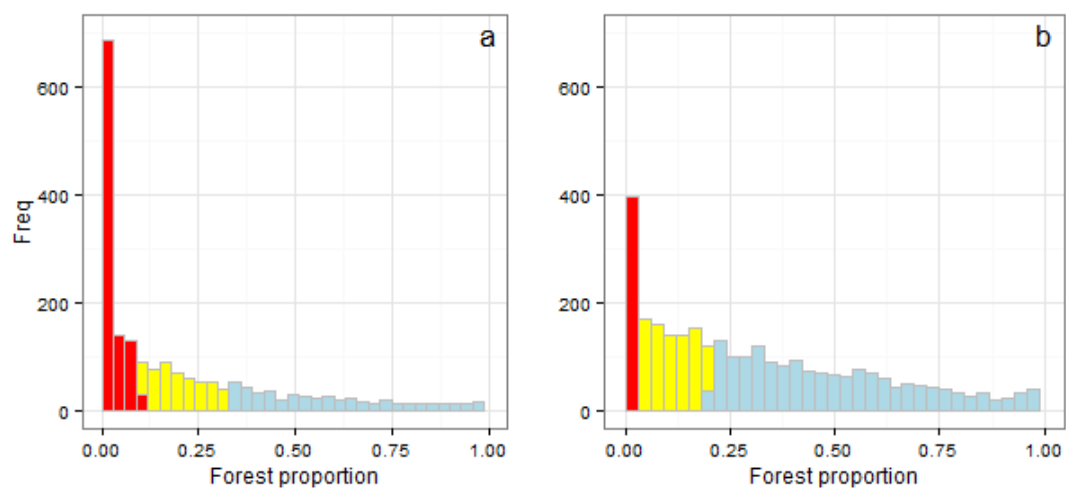

Figure 3. Proportion of total (both closed-canopy and degraded) forest within the 150-m radius buffers for headwater (a) and riparian (b) forests. Bars in blue represent buffers that complied with the legally prescribed requirement according to the previous legislation; bars in yellow represent buffers that were not in compliance before, but now comply with the current requirements; and bars in red represent non-compliant cases with both the previous and the current legislation. 
Table 1. Proportion of farms complying with both the previous and the current Forest Code (FC) per landholding size class, considering the amount of headwater and riparian forest maintained within a 150-m buffer.

\begin{tabular}{ccccc}
\hline & \multicolumn{4}{c}{ Landholding size class (ha) } \\
\cline { 2 - 5 } Headwater buffers & $<100$ & $100-200$ & $200-400$ & $>400$ \\
\cline { 2 - 5 } Previous FC & $20.32 \%$ & $26.99 \%$ & $40.16 \%$ & $67.16 \%$ \\
Current FC & $36.01 \%$ & $46.37 \%$ & $71.31 \%$ & $88.56 \%$ \\
Total count & 1422 & 289 & 122 & 201 \\
& & & & \\
Riparian buffers & & & & \\
Previous FC & $51.01 \%$ & $74.85 \%$ & $83.33 \%$ & $94.12 \%$ \\
Current FC & $82.15 \%$ & $95.03 \%$ & $91.67 \%$ & $94.12 \%$ \\
Total count & 2280 & 342 & 132 & 204 \\
\hline
\end{tabular}

Under the previous FC, there was a restoration deficit of headwater forests of 3,429 hectares, and both very small and very large landholdings shared almost equal responsibility for it. Class 1 landholdings ( $<100 \mathrm{ha}$ ) accounted for $44 \%$ of the total area to be restored, while Class 4 landholdings accounted for $40 \%$ of the deficit. The recent changes in legislation will pardon almost $88 \%$ of those requirements. Riparian forests within the landholdings had a slightly smaller restoration deficit of 2,623 hectares, and small landholdings were responsible for $61 \%$ of that deficit. The recent changes in legislation has accounted for a drop of more than 2,389 hectares (approximately 91\%) in the restoration requirements, with small landholders benefiting most from this change (Table 1).

Headwater remnants responded positively to landholding size for both forest amount and forest quality with a stronger effect observed in the latter (Figure $4 \mathrm{a}$ and $4 \mathrm{~b}$ ). The state of headwater forests, although positively associated with landholding size, presented a greater variation within each size class, indicating that many of these remnants are poorly protected even within large landholdings (Figure 5a). Headwater forest retention varies widely in Alta Floresta (forest proportion $=0.23 \pm 0.28$ ), with a large number of headwater remnants being almost entirely cleared throughout the whole county (SM1), and the remaining patches are in highly variable state $(\mathrm{CCF}$ proportion $=0.38 \pm 0.37)$. Riparian forests, on the other hand, are generally more often retained (forest proportion $=0.59 \pm 0.35)$, although also in variable quality $(\mathrm{CCF}$ 
proportion $=0.33 \pm 0.28$; Figure $5 \mathrm{~b}$ and $\mathrm{SM} 2$ ), but neither amount nor quality responded strongly to landholding size (Figure $4 \mathrm{c}$ and $4 \mathrm{~d}$ ).
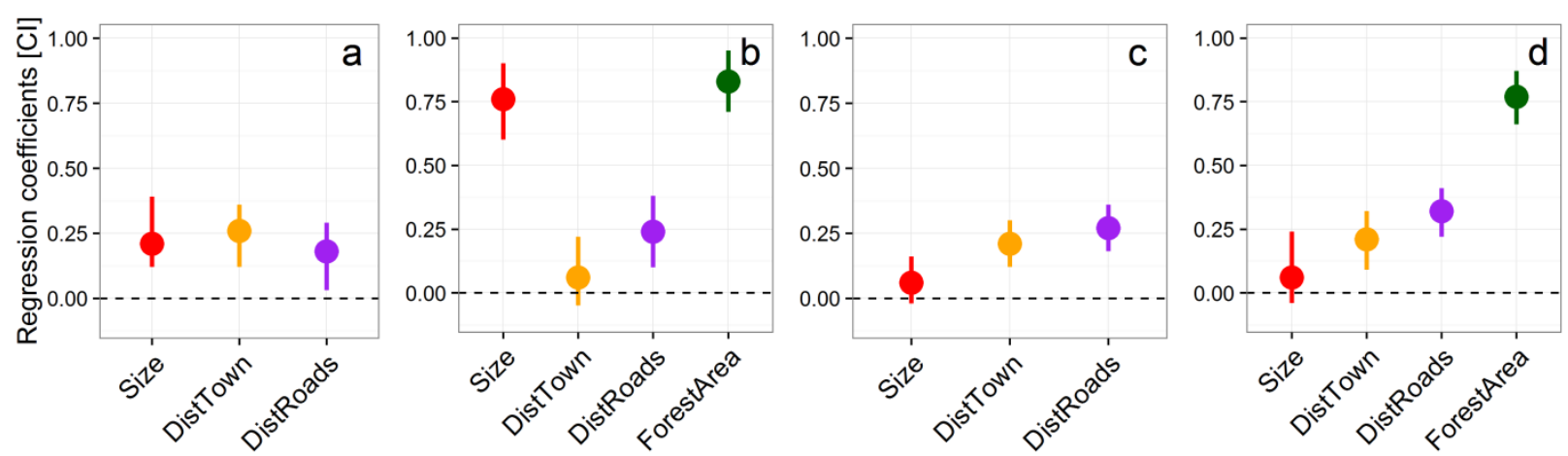

Figure 4. Regression coefficient values (and 95\% confidence intervals) for all variables included in the global models, and obtained by model averaging. Models generated for: a) headwater forest amount; b) headwater forest quality; c) riparian forest amount; and d) riparian forest quality.
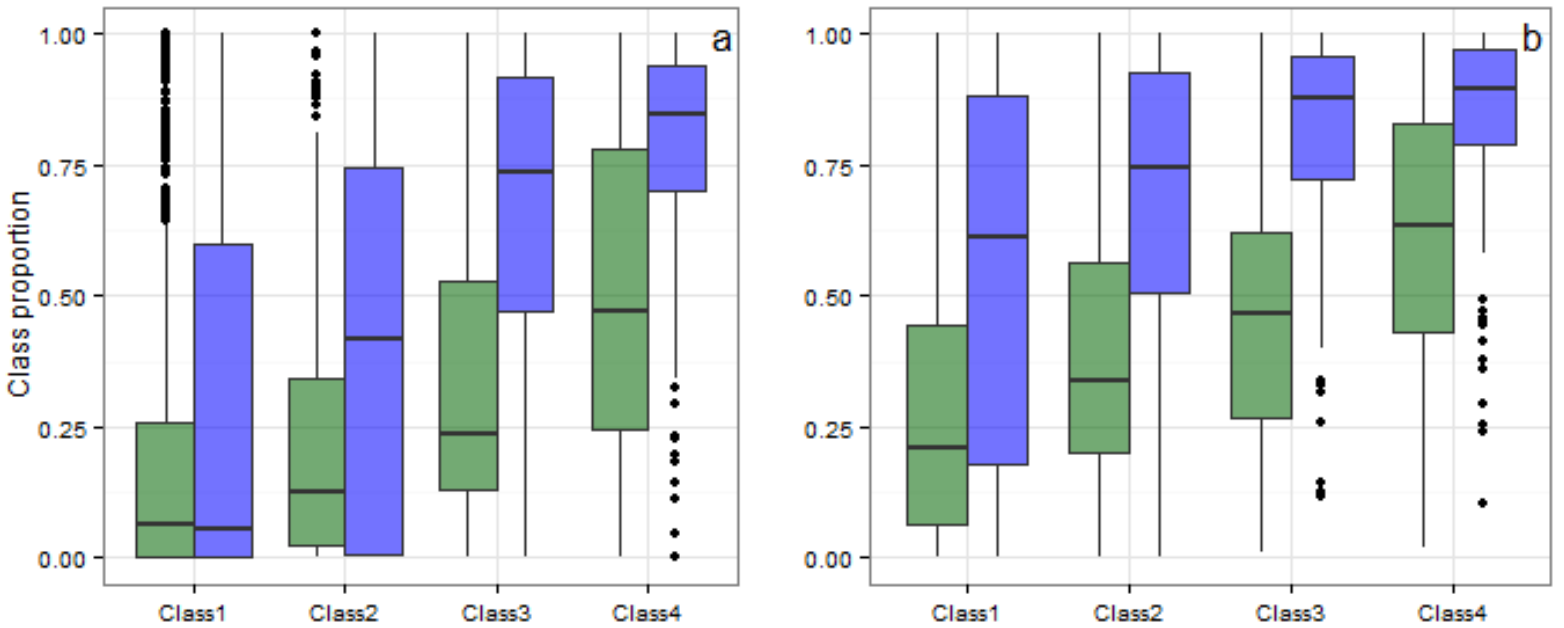

Figure 5. Proportion of total forest (in green) and proportion of closed-canopy forest (in blue) are

positively associated with the landholding size classes for both headwater (a) and riparian (b) forests. Class 1: smaller than 100 ha; Class 2: between 100 and 200 ha; Class 3: between 200 and 400 ha; and Class 4: larger than 400 ha.

Also in accordance with our working hypothesis, both distance to town and distance to 345 primary and secondary roads appeared to be positively associated with riparian forest amount and quality (Figures 6 and 7, and SM3). However, distance to town was not related to headwater remnant quality (Figure 4b), and distance to roads was found to be a predictor of both headwater 
and riparian forest amount (Figure $4 \mathrm{a}$ and $4 \mathrm{c}$ ). The overall proportion of forest within the landholdings was also selected as a predictor variable in the best models (Figure 4b and 4d), corroborating an expected area effect on forest quality.
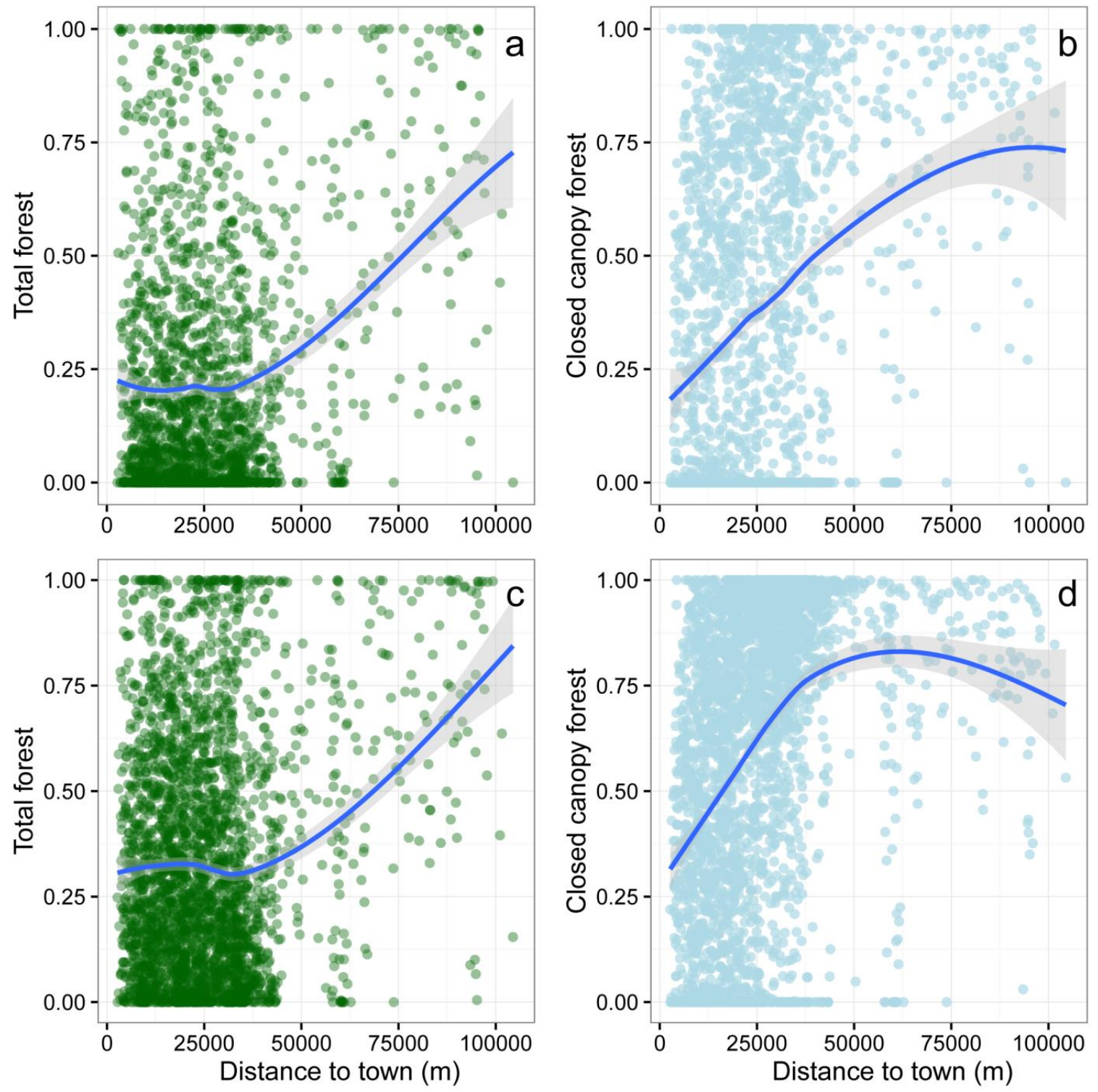

Figure 6. Distance to the city of Alta Floresta (m) positively affects forest amount (in green) and quality (in blue), for both headwater ( $a$ and b) and riparian (c and d) forests. 

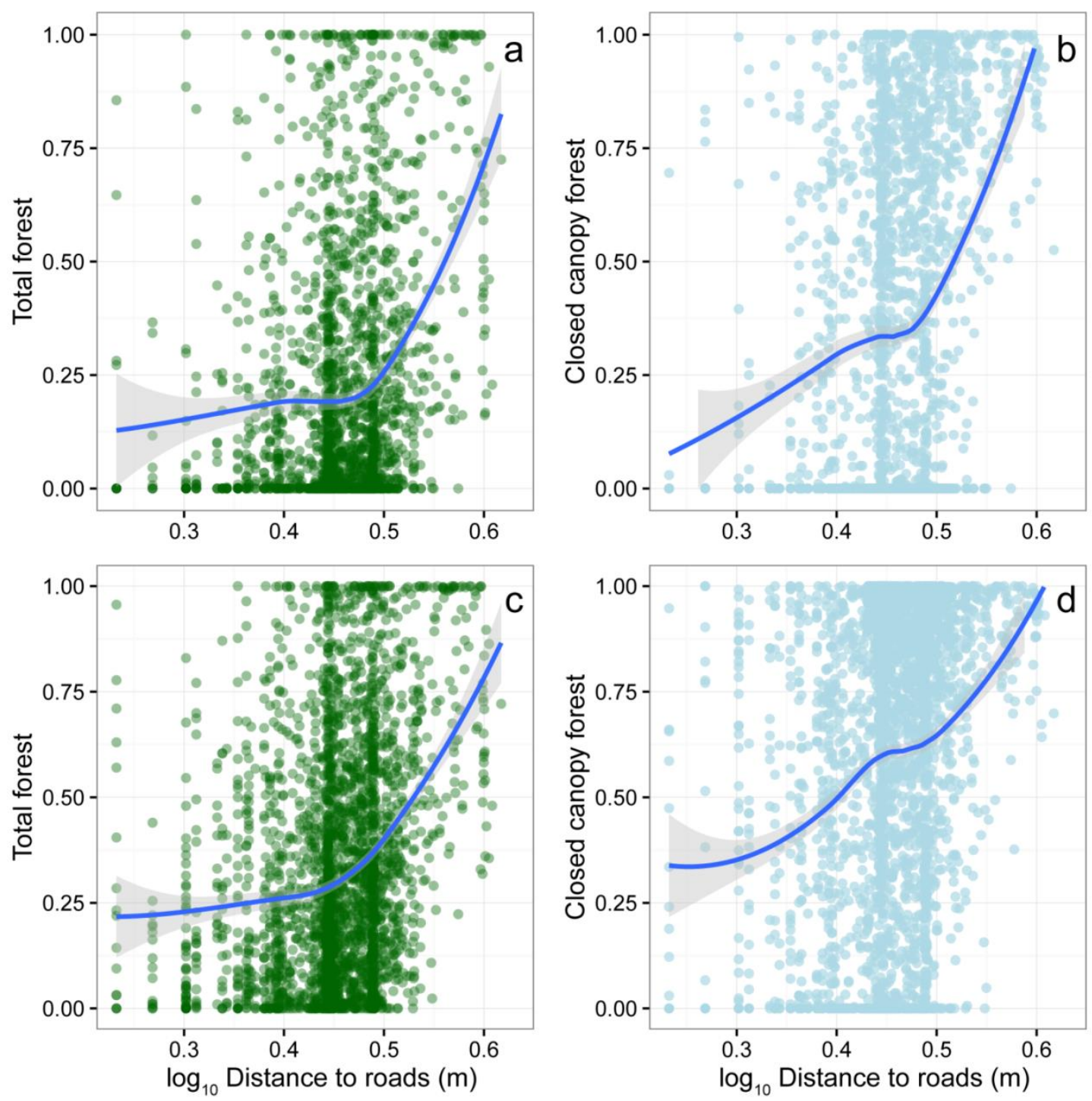

Figure 7. Distance to primary and secondary roads (m) positively affects forest amount (in green) and quality (in blue), for both headwater ( $a$ and b) and riparian ( $c$ and d) forests.

Model selection at the scale of individual patches indicated a positive relationship between forest quality and width at the local scale, suggesting an edge effect of riparian forest amount on forest degradation (Figure 8a, SM4, regression coefficient $[\mathrm{CI}]=0.44$ [0.19-0.66]). A post hoc piecewise regression indicated a threshold effect of width on forest quality, with a steeper forest quality loss in corridors narrower than $120 \mathrm{~m}$ (Figure 8a; post hoc piecewise regression: adjusted $\left.\mathrm{R}^{2}=0.34, \mathrm{p}<0.001\right)$. We did not observe an effect of landholding size class, distance to towns, distance to roads or cattle intrusion on forest quality. However, one of the 
most pervasive impacts observed at the local scale was the penetration of cattle into the riparian forest to have access to water, which was elucidated by our exploratory analyses among in situ variables. Cattle trample the ground within the forest, impairing the recruitment and growth of new vegetation, and severely affecting the forest understory (Figure 8b, linear regression: adjusted $\mathrm{R}^{2}=0.25$ ). This effect, however, is most likely invisible from a remote-sensing approach, which captures mainly openings in the canopy.
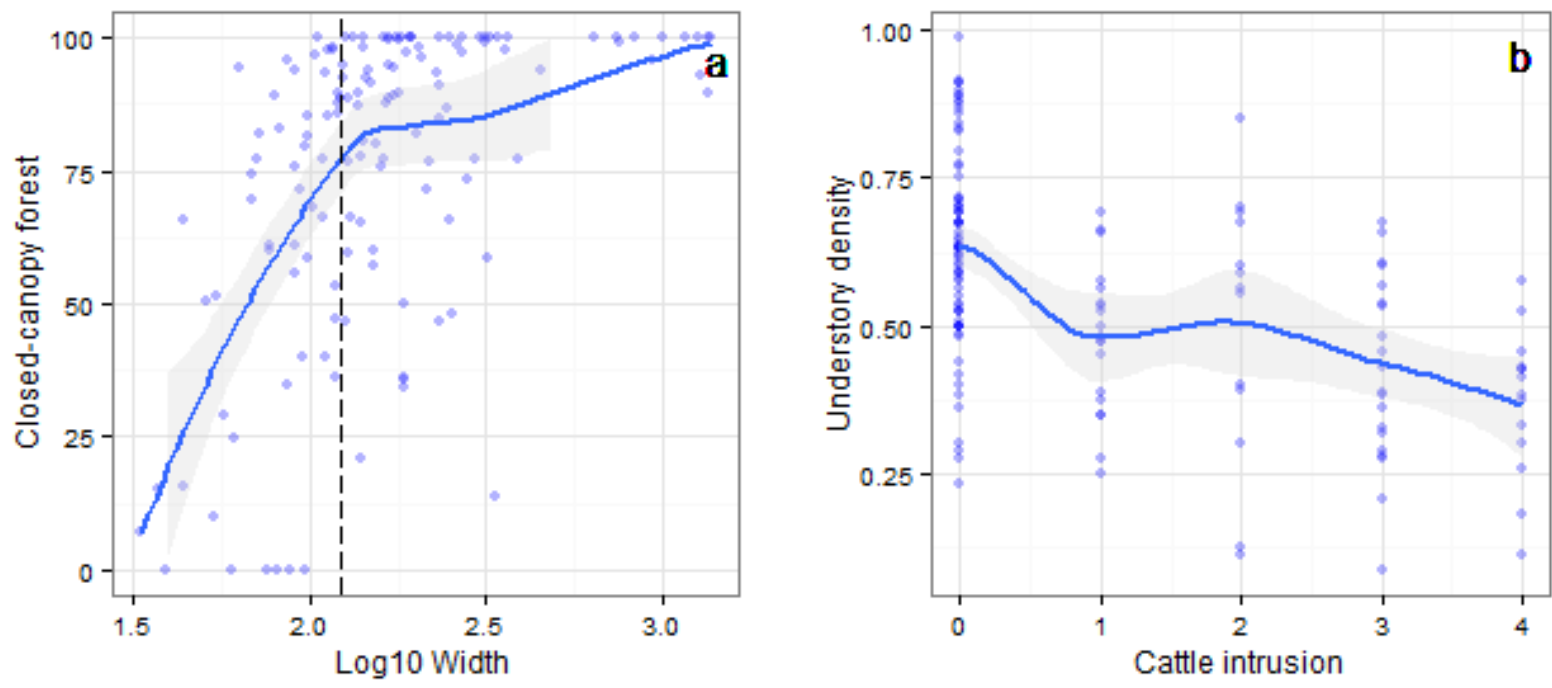

Figure 8 . Forest quality measured as closed-canopy proportion within 150-m buffers is highly 375 and positively associated with riparian forest width, with a threshold effect at $120 \mathrm{~m}$ (a). Forest quality measured as understory density is negatively affected by the degree of cattle intrusion within the riparian forests (b). Cattle intrusion was measured as a subjective ordinated variable, where the classes represent (0) no evidence of cattle trampling; (1) rare; (2) occasional; (3) frequent; and (4) very severe trampling.

Finally, we observed an association between riparian forest quality and the vertical profiles. Forest degradation causes an increase in tree height variability within the forest, which we observed in the negative association between closed-canopy forest within the buffers and the coefficient of variation of height in the profile images (SM5). Also, an overall decrease in forest height was expected to be observed in severely degraded forests, which we corroborated by finding a positive relationship between forest quality and the profile total pixel count (SM5). These associations however were found to be weak, perhaps suggesting that highly degraded edges in riparian forests appear to be generally the case, and may not be a strong indicator of the 
internal forest quality, especially where forest width is large. Surprisingly, we found no evidence

390 of a significant relationship between canopy density and closed-canopy forest proportion (SM6).

Other variables measured in situ were not found to have an association with the remotely assessed forest quality (SM6), suggesting a limitation of remote-sensing approaches to capture internal forest structural features.

Discussion

Forest loss and degradation are commonly associated, but forest degradation can also respond independently to the some of the same drivers. In our study area, headwater forests were generally in worse conditions than riparian forests, and both large and small landholders tended to clear their headwater zones beyond their legal requirements, often removing them entirely.

400 The quality of headwater patches responded more strongly to landholding size than overall forest amount, which could indicate that large landholders keep headwater forests in a better structural state independent on the amount protected. Riparian areas were not clearly affected by landholding size, in contrast with what was found by other studies in the Amazon region (Michalski et al. 2010a; Godar et al. 2012), suggesting a great variation between landowner 405 attitudes towards riparian forests in all landholding size classes. Smaller landholders however generally comply with the legislation less often than large landholders. Smaller landholders incur in higher opportunity costs to keep proportional forest remnants within their properties, comparing with larger landholders (Gardner et al. 2009; Michalski et al. 2010a). They also tend to live off their land in a more intensive way, for instance by timber extraction and by allowing 410 the cattle into forest patches to have access to water and shade. Often in small farms, cattle intrusion into riparian forests is a major driver of the forest quality degradation (Kauffman \& Krueger 1984; Lees \& Peres 2008). The effect of cattle intrusion on understory density corroborates the impact of cattle trampling and overgrazing within the forest on internal forest quality. To some extent, this phenomenon takes place in large landholdings as well, but, in

415 contrast, generally one focal site within the forest is allowed to be accessed by the cattle, rather than the entire length of the riparian strip.

Road networks have been demonstrated to impact forest dependent biodiversity at larger scales (Aguiar et al. 2007; Moura et al. 2014), and here we demonstrate that this effect holds at a 
higher spatial resolution, since headwater and riparian forest quality and amount responded to

420 distance to primary and secondary roads. At regional scales, roads represent a greater access to otherwise isolated tracts of forest and literally pave the way for direct drivers of disturbance, such as logging activities, wildfire, and hunting (Peres et al. 2006). At more local scales, roads are associated with the age of the landholdings, with older properties having been established close to main primary and secondary roads, while more recent properties have been accessed by

425 more distant and smaller privately opened and managed roads. The county's official road network thus acts as a proxy for the time when the deforestation took place within landholdings. Age plays an important role in the amount of forest retention and the type of management practiced within the remnants (Pfaff 1999). Michalski et al. (2010a), working in the same region, have noted that more recently established properties tended to retain larger amount of riparian 430 forest, and this pattern was true even for smaller landholdings. Even though the vegetation that has undergone deforestation in the more distant past may in some cases have had the chance to regenerate, we hypothesized that, in most cases, older deforestation actions will contribute to a more severe forest degradation pattern, since the exploration of the patches' resources (e.g. logging, hunting, cattle intrusion) were and still are common practice throughout the region.

435 Moreover, access by larger roads can also determine how intensively the forests have been logged in the past, due to logistic restrictions of accessing remote forests with heavy equipment.

All dependent variables, excepting headwater remnant quality, also responded to distance to town. The urban pressure we detected on riparian patches close to the town of Alta Floresta from our experience living in the study region throughout the length of the study included leisure activities, fishing, and hunting. A few riparian strips were also used by part of the population to illegally discard trash, and were consequently littered with garbage. Even though the town is not a large town, with under 50,000 inhabitants, the amount of pressure exerted on forest remnants is extensive.

Because the landholding system in the region is highly heterogeneous, so are local drivers 445 and management opportunities. The context in which deforestation and degradation occurs is more relevantly assessed at a meso-scale, such as at the level of entire counties, and the implementation of management strategies will also take place ultimately at this scale (Gardner et al. 2013). Understanding the specific context and drivers of anthropogenic impacts in the region include identifying why small landholders clear and degrade their remnant patches, and this 
450 information will be important to define strategies that would work locally (Arias 2015). The fact that both forest clearing and degradation respond synergistically to the same drivers in similar ways is indicative that focused actions, if correctly defined, can promote the protection of both forest amount and quality in the region. Small landholders present different motivations and behaviors, but the lower compliance rates observed for this landholding size class are not necessarily related to a negative attitude towards forest preservation (Coudel et al. 2012), and could be related to a lack of access to information, credit, and technical support that would promote compliance (Gardner et al. 2013; Arias 2015; Nunes et al. 2015). In the Brazilian 'arc of deforestation', counties that are more accessible to state capitals and other parts of Brazil are more heavily subjected to law enforcement actions, and would be more policy-responsive, as is 460 the case of Alta Floresta (Godar et al. 2014). These factors suggest that the study region is suitable for the implementation of well-planned management efforts to improve compliance.

Successful past actions to curb deforestation, in order to remove Alta Floresta from the Red List of counties with the highest deforestation rates, have demonstrated that landholders are often willing to get involved in forest preservation and restoration projects. However, most

465 efforts have focused on medium to large landholders, with sanctions on credit and market access (Coudel et al. 2012). Applying strong sanctions to smaller and often poorer landholders is less socially acceptable, can be seen as illegitimate, and create conflicts (Godar et al. 2014; Arias 2015). Smaller landholders may respond better to monetary incentives such as PES systems (payment for ecosystem services), which are still relatively rare in the Brazilian Amazon (Coudel 470 et al. 2012; Garcia et al. 2013; Peres et al. 2013). As previously noted, we lack a more thorough understanding of the ecological and socioeconomic impacts of different management strategies applied to the heterogeneous set of stakeholders involved in forest conversion in the Amazon (Gardner et al. 2013). The assessment of the motivations behind their behaviors and the identification of conflicts of interest is a necessary first step to determine which - and where -

475 actions will more likely be successful, while we recognize that there are fundamental societal trade-offs between land use for agriculture and ranching, and land sparing for conservation (Defries et al. 2004; Gardner et al. 2009).

The recent changes in policy with the 2012 Forest Code, however, are a contrary influence. The first efforts should be to make sure the landholders comply with the legislation, because considering even the very lenient set of requirements, compliance rates are still not high, 
especially for headwater forests. Addressing forest quality, on the other hand, is entirely independent on legislation, since the FC does not make requirements regarding the state of the forest to be maintained or restored by stating that the native vegetation in APPs must be primary or secondary in any stage of regeneration. Thus, even in a scenario of full compliance, we may

485 still end up with a landscape of overall highly degraded forest patches. Recent incentives within a municipal project in the region for the fencing and restoration of headwater patches and riparian strips have been implemented, in which monetary and technical support were given especially to small landholders (Projeto Olhos D’Água da Amazônia, Alta Floresta, 2014). The fencing of riparian forests will deal with the most widespread source of forest disturbance and 490 degradation, which is the grazing and trampling of the vegetation by the cattle. However, monitoring forest degradation is not as straightforward as monitoring forest loss, as we have seen from the lack of association between forest structural variables obtained in situ and from the remote-sensing approach. Also, other pervasive but inconspicuous sources of disturbances, such as understory fires and hunting, are difficult to detect from afar and may play an important role 495 in the ecological functioning of forest remnants (Peres et al. 2006).

The FC also states that it is mandatory for all farmers to register their properties and declare the amount and location of all their forest patches in an official digital database, the national rural environmental registry (CAR, in Portuguese). This database is in advanced state in Alta Floresta, due to concentrated efforts from the municipal town hall, and it is potentially a 500 powerful tool to monitor compliance and plan restoration efforts. The inclusion of small properties in the CAR is a priority, since many small landholders chose not to face the costs of mapping their properties and forest patches. In Alta Floresta, the town hall has financed the small landholders' costs for their inclusion in the CAR database, in a project funded by the Amazonia Fund. Even with a complete CAR system, however, very few landholders have obtained their full property environmental license (LAR, in Portuguese), which is the next step after the registering of the property, and a necessary tool to implement and safeguard compliance (Nunes et al. 2015).

Riparian APPs are the best opportunity available in Brazil for the planning of a connectivity network that would serve as landscape connectors at local and regional scales to 510 safeguard ecosystem functions and biodiversity (Peres et al. 2010). Beyond compliance with the legislation, the identification of strategic sites under pressure is important to help focus 
conservation priorities, and promote the implementation of such measures. There is no legal tool that explicitly requires such planning, and efforts will need to be fostered by other means, since the amount of forest currently required by law has already been shown to be inefficient in safeguarding protection from the perspective of biodiversity conservation (Lima \& Gascon 1999; Lees \& Peres 2008; De Fraga et al. 2011; Bueno et al. 2012; Garcia et al. 2013). Successful actions in the past have shown that curbing deforestation can be accomplished, but the regeneration of forest quality must also be included in the discussion, since the limited value of lower quality remnants for connectivity has already been demonstrated (Harrison 1992; Bennett et al. 1994; Lees \& Peres 2008). Therefore, making sure that landholders comply with the legislation is just the initial stage of planning for effective conservation in the region. Actions will not necessarily need to aim at restoring the landscape to the previous undisturbed state, but should have clear goals as to what level of landscape functioning will be accomplished by management (Metzger \& Brancalion 2013), and that knowledge, while of high priority for 525 conservation, is currently lacking.

\section{Acknowledgments}

We are grateful to the Brazilian Ministry of Education (CAPES) for funding BZ's PhD studentship. We thank the University of East Anglia for hosting BZ during a study visit. CNPq provided a research grant (\#306392/2013-5) to RBM. We also thank IdeaWild Organization, Rufford Small Grants Foundation (\#12658-1), the National Geographic Society/Waitt Grant (\#W314-14), and a CAPES grant to CAP (004-2012) for financial support for the fieldwork in Mato Grosso, Brazil. We are indebted to all landowners for granting access to their properties.

Aguiar APD, Câmara G, Escada MIS. 2007. Spatial statistical analysis of land-use determinants in the Brazilian Amazonia: Exploring intra-regional heterogeneity. Ecological Modelling 209:169-188.

Aldrich SP, Walker RT, Arima EY, Caldas MM. 2006. Land-cover and land-use change in the Brazilian Amazon: Smallholders, ranchers, and frontier stratification. Economic Geography 82:265-288. 
Arias A. 2015. Understanding and managing compliance in the nature conservation context. Journal of Environmental Management 153:134-143.

Banks-Leite C et al. 2014. Using ecological thresholds to evaluate the costs and benefits of setasides in a biodiversity hotspot. Science 345:1041-1045.

Bennett AF, Henein K, Merriam G. 1994. Corridor use and the elements of corridor quality: chipmunks and fencerows in a farmland mosaic. Biological Conservation 68:155-165.

Brasil. 2012. Código Florestal Brasileiro - Lei 12.651 de 25 de maio de 2012. Diário Oficial da União de 28 de maio de 2012.

Bueno AS, Bruno RS, Pimentel TP, Sanaiotti TM, Magnusson WE. 2012. The width of riparian habitats for understory birds in an Amazonian forest. Ecological applications : a publication of the Ecological Society of America 22:722-34.

Burnham KP, Anderson DR. 2002. Model selection and multimodel inference: a practical informaion-theoretic approach. 488pp. Springer, New York.

555 Coudel AE, Piketty M-G, Gardner TA, Viana C, Ferreira JN, Morello T, Parry L, Universidade USP, Paulo DESÃO. 2012. Environmental compliance in the Brazilian Amazon : exploring motivations and institutional conditions 2010:1-34.

De Fraga R, Lima AP, Magnusson WE. 2011. Mesoscale spatial ecology of a tropical snake assemblage: the width of riparian corridors in central Amazonia. Herpetological Journal 21:51-57.

Defries RS, Foley JA, Asner GP. 2004. Land-use choices : balancing human needs and ecosystem function. Frontiers in Ecology and the Environment 2:249-257.

Diniz-Filho JAF, Bini LM. 2005. Modelling geographical patterns in species richness using eigenvector-based spatial filters. Global Ecology and Biogeography 14:177-185.

565 Ferreira J, Pardini R, Metzger JP, Fonseca CR, Pompeu PS, Sparovek G, Louzada J. 2012. Towards environmentally sustainable agriculture in Brazil: Challenges and opportunities for applied ecological research. Journal of Applied Ecology 49:535-541.

Foley JA et al. 2007. Amazonia revealed: forest degradation and loss of ecosystem goods and services in the Amazon Basin. Frontiers in Ecology and the Environment 5:25-32.

570 Garcia LC, dos Santos JS, Matsumoto M, Silva TSF, Padovezi A, Sparovek G, Hobbs RJ. 2013. Restoration challenges and opportunities for increasing landscape connectivity under the new Brazilian forest act. Natureza a Conservacao 11:181-185.

Gardner TA et al. 2012. A framework for integrating biodiversity concerns into national REDD+ programmes. Biological Conservation 154:61-71. 
575 Gardner TA et al. 2013. A social and ecological assessment of tropical land uses at multiple scales: the Sustainable Amazon Network. Philosophical transactions of the Royal Society, Series B 368:20120166.

Gardner TA, Barlow J, Chazdon R, Ewers RM, Harvey CA, Peres CA, Sodhi NS. 2009. Prospects for tropical forest biodiversity in a human-modified world. Ecology Letters 12:561-582.

Geist HJ, Lambin EF. 2002. Proximate Causes and Underlying Driving Forces of Tropical Deforestation. BioScience 52:143.

Godar J, Gardner T a., Tizado EJ, Pacheco P. 2014. Actor-specific contributions to the deforestation slowdown in the Brazilian Amazon. Proceedings of the National Academy of Sciences 111:15591-15596.

Godar J, Tizado EJ, Pokorny B. 2012. Who is responsible for deforestation in the Amazon? A spatially explicit analysis along the Transamazon Highway in Brazil. Forest Ecology and Management 267:58-73.

Harrison RL. 1992. Toward a Theory of Inter-Refuge Corridor Design. Conservation Biology 6:293-295.

Harrison X a. 2014. Using observation-level random effects to model overdispersion in count data in ecology and evolution. PeerJ 2:e616.

IBGE/SIDRA. 2016. Instituto Brasileiro de Geografia e Estatística/Sistema de Recuperação Automática. http://www.sidra.ibge.gov.br/

595 Kauffman JB, Krueger WC. 1984. Livestock impacts on riparian ecosystems and streamside management implications - a review. Journal of Range Management 37:430-438.

Keuroghlian a., Eaton DP. 2008. Importance of rare habitats and riparian zones in a tropical forest fragment: Preferential use by Tayassu pecari, a wide-ranging frugivore. Journal of Zoology 275:283-293.

Lees AC, Peres CA. 2008. Conservation value of remnant riparian forest corridors of varying quality for amazonian birds and mammals. Conservation Biology 22:439-449.

Lewinsohn TM. 2010. A ABECO e o Código Florestal Brasileiro. Natureza \& Conservação 08:100-101.

Lima M, Gascon C. 1999. The conservation value of linear forest remnants in central Amazonia. Biological Conservation 91:241-247. 
Maltchik L, Peixoto CD, Stenert C, Moreira LFB, Machado IF. 2008. Dynamics of the terrestrial amphibian assemblage in a flooded riparian forest fragment in a Neotropical region in the south of Brazil. Brazilian Journal of Biology 68:763-9.

Martensen AC, Pimentel RG, Metzger JP. 2008. Relative effects of fragment size and connectivity on bird community in the Atlantic Rain Forest: Implications for conservation. Biological Conservation 141:2184-2192.

Metzger JP, Brancalion PHS. 2013. Challenges and opportunities in applying a landscape ecology perspective in ecological restoration: A powerful approach to Shape Neolandscapes. Natureza e Conservacao 11:103-107.

Metzger JP, Lewinsohn TM, Joly CA, Verdade LM, Martinelli LA, Rodrigues RR. 2010. Brazilian Law: Full Speed in Reverse? Science 329:276-277.

Michalski F, Metzger JP, Peres CA. 2010. Rural property size drives patterns of upland and riparian forest retention in a tropical deforestation frontier. Global Environmental Change 20:705-712.

Michalski F, Norris D, Peres CA. 2010. No Return from Biodiversity Loss. Science 329:1282.

Michalski F, Peres CA, Lake IR. 2008. Deforestation dynamics in a fragmented region of southern Amazonia: evaluation and future scenarios. Environmental Conservation 35:93103.

Moura G, Gardner TA, Ahmed SE, Lees AC, Barlow J, Ferreira J, Ewers RM. 2014. Road networks predict human influence on Amazonian bird communities. Proc. R. Soc. B 281: 20141742.

Naiman RJ, Decamps H, Pollock M. 1993. The Role of Riparian Corridors in Maintaining Regional Biodiversity. Ecological Applications 3:209-212.

Nunes SS, Barlow J, Gardner T a., Siqueira J V., Sales MR, Souza CM. 2015. A 22 year assessment of deforestation and restoration in riparian forests in the eastern Brazilian Amazon. Environmental Conservation 42:193-203.

Peres CA, Barlow J, Gardner TA, Vieira ICG. 2013. Conservação da biodiversidade em paisagens antropizadas do Brasil. 587pp. UFPR, Curitiba.

Peres CA, Barlow J, Laurance WF. 2006. Detecting anthropogenic disturbance in tropical forests. Trends in ecology \& evolution 21:227-229.

Peres CA, Gardner TA, Barlow J, Zuanon J, Michalski F, Lees AC, Vieira ICG, Moreira FMS, Feeley KJ. 2010. Biodiversity conservation in human-modified Amazonian forest landscapes. Biological Conservation 143:2314-2327. 
Perfecto I, Vandermeer J. 2008. Biodiversity conservation in tropical agroecosystems: a new conservation paradigm. Annals of the New York Academy of Sciences 1134:173-200.

Pfaff ASP. 1999. What Drives Deforestation in the Brazilian Amazon? Journal of Environmental Economics and Management 37:26-43.

Quigley HB, Crawshaw Jr. PG. 1992. A conservation plan for the jaguar Panthera onca in the Pantanal region of Brazil. Biological Conservation 61:149-157.

645 Rangel TF, Diniz-Filho JAF, Bini LM. 2010. SAM: a comprehensive application for Spatial Analysis in Macroecology. Ecography 33:46-50.

R Development Core Team. 2014. R: a language and environmental for statistical computing. R Foundation for Statistical Computing, Vienna, Austria. http://cranr-project.org

Soler LDS, Escada MIS, Verburg PH. 2009. Quantifying deforestation and secondary forest determinants for different spatial extents in an Amazonian colonization frontier (Rondonia). Applied Geography 29:182-193.

Uezu A, Metzger JP, Vielliard JME. 2005. Effects of structural and functional connectivity and patch size on the abundance of seven Atlantic Forest bird species. Biological Conservation 123:507-519. 


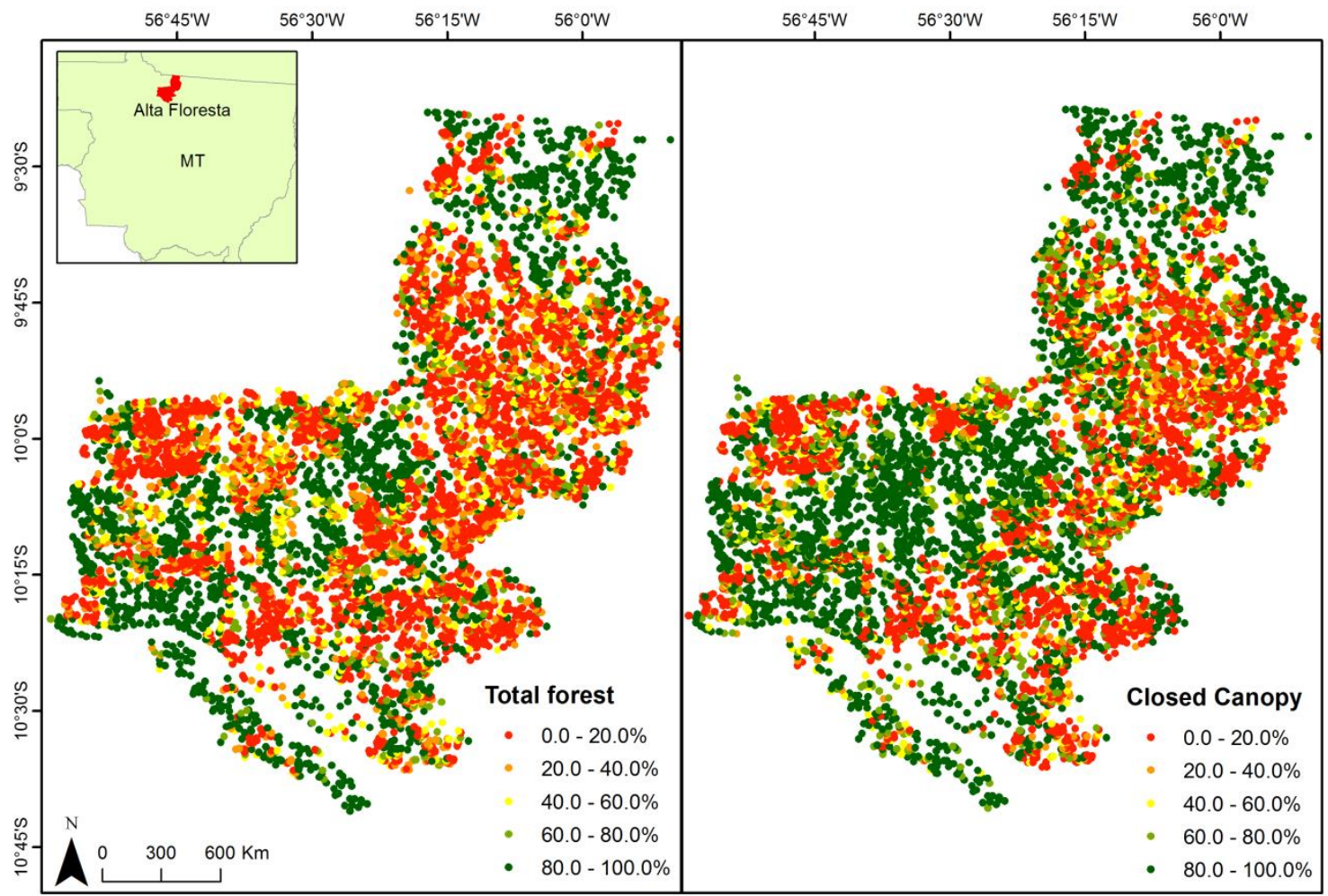

658

659 SM1. Heatmaps for the state of headwater forests throughout the Alta Floresta county, in Mato 660 Grosso, Brazil.

661 


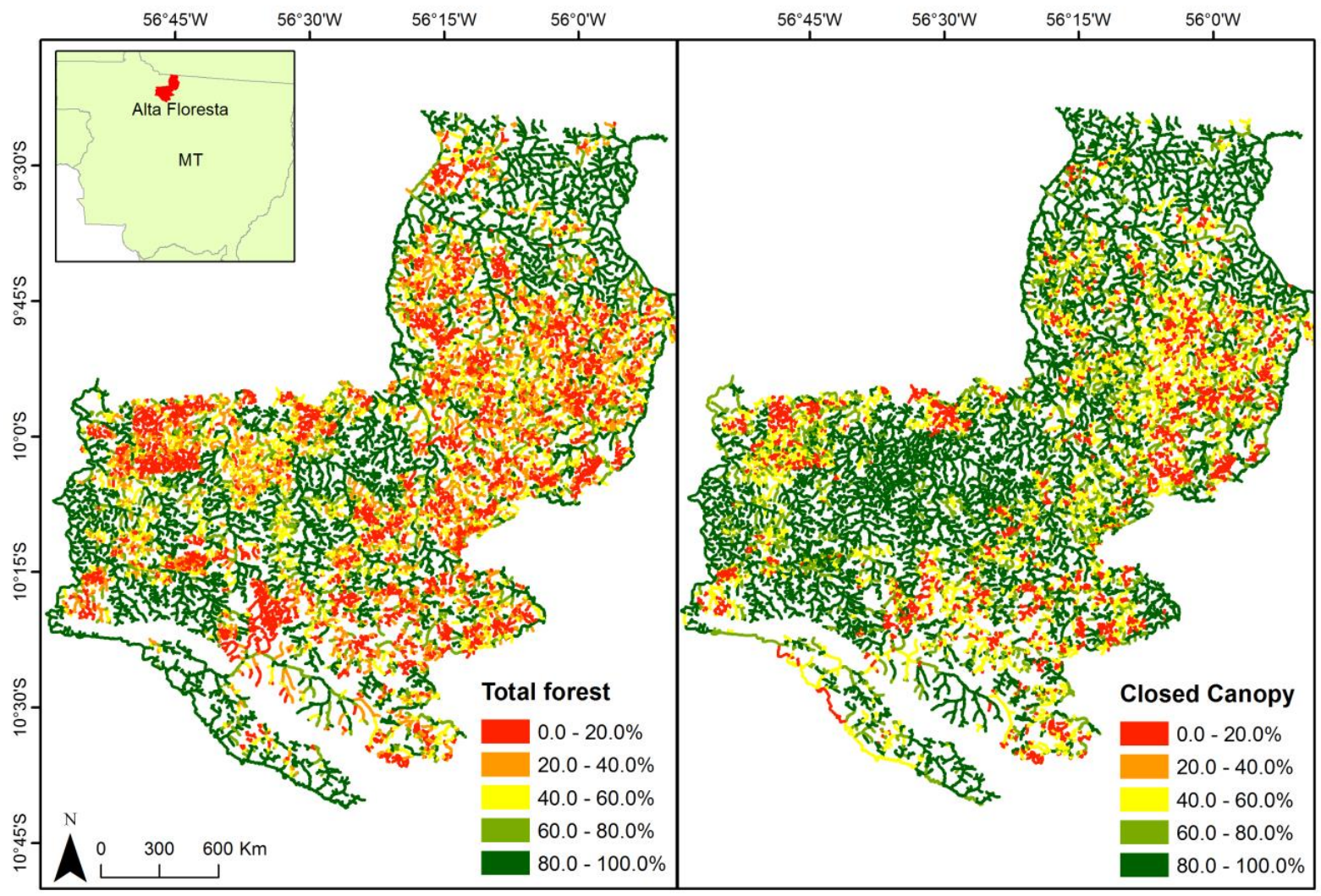

662

663 SM2. Heatmaps for the state of riparian forests throughout the Alta Floresta county, in Mato 664 Grosso, Brazil. 
SM3. Model selection results for generalized linear models with $\triangle \mathrm{AIC}<5$, for the assessment of regional explanatory variables of total forest amount (in a 150-m buffer) and quality (proportion of closed-canopy forest) for both headwater and riparian forests. Int = intercept; Size = landholding size (ha); Dist town = distance to town (m); Dist roads = distance to primary and secondary roads $(\mathrm{m})$; $\mathrm{FA}=$ total forest area within landholding (ha).

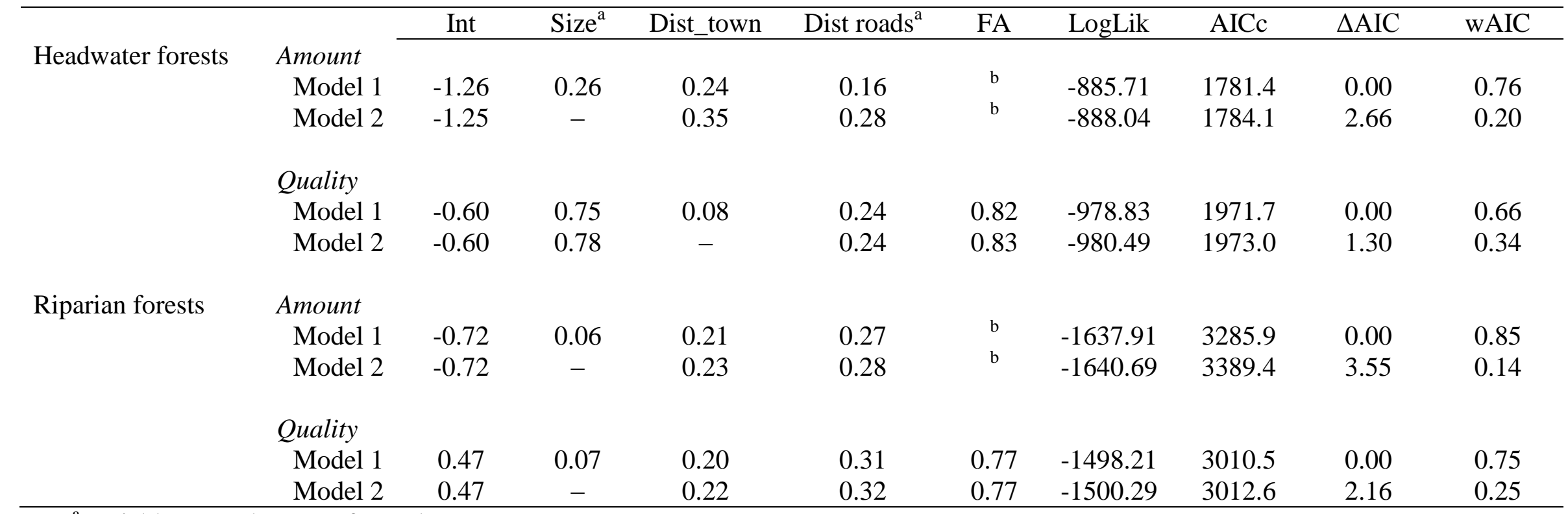

${ }^{\mathrm{a}}$ Variables were log-transformed.

670 bariable not included in the model.

675 
SM4. Model selection results for generalized linear mixed-effect models models with $\triangle \mathrm{AIC}<5$, for the assessment of local explanatory variables of riparian forest quality (proportion of closed-canopy forest in a 50-m radius around each sampling site). Int $=$ intercept; Size class = landholding size class (Class 1- smaller than 100 ha; Class 2- between 100 and 200 ha; Class 3- between 200 and 400 ha; and Class 4- larger than 400 ha); Cattle access = degree of cattle intrusion within the forest (0- no cattle access at all; 1very rare; 2 - moderately frequent; 3- frequent; and 4- extremely frequent cattle intrusion); Dist towns = distance to nearest town (m); Dist roads $=$ distance to primary and secondary roads $(\mathrm{m})$; Width = manually measured width in a transversal section of the riparian forest at the sampling point $(\mathrm{m})$.

\begin{tabular}{rcccccccccc}
\hline & Int & Size class & Cattle access & Dist towns & Dist roads $^{*}$ & Width $^{*}$ & LogLik & AICc & $\Delta$ AIC & wAIC \\
\cline { 2 - 10 } Model 1 & 2.81 & - & - & - & - & 0.45 & -10463.47 & 20935.2 & 0.00 & 0.24 \\
Model 2 & 2.45 & 0.14 & - & - & - & 0.43 & -10462.77 & 20936.0 & 0.75 & 0.16 \\
Model 3 & 2.81 & - & - & - & 0.05 & 0.45 & -10463.35 & 20937.2 & 1.92 & 0.09 \\
Model 4 & 2.81 & - & - & 0.04 & - & 0.45 & -10463.43 & 20937.3 & 2.07 & 0.08 \\
Model 5 & 2.80 & - & 0.01 & - & - & 0.45 & -10463.44 & 20937.3 & 2.10 & 0.08 \\
Model 6 & 2.39 & 0.17 & - & -0.06 & - & 0.42 & -10462.70 & 20938.0 & 2.79 & 0.06 \\
Model 7 & 2.44 & 0.14 & 0.01 & - & - & 0.43 & -10462.74 & 20938.1 & 2.88 & 0.06 \\
Model 8 & 2.47 & 0.14 & - & - & 0.01 & 0.43 & -10462.76 & 20938.1 & 2.92 & 0.06 \\
Model 9 & 2.80 & - & 0.02 & - & 0.05 & 0.45 & -10463.31 & 20939.3 & 4.02 & 0.03 \\
Model 10 & 2.81 & - & - & 0.02 & 0.04 & 0.45 & -10463.34 & 20939.3 & 4.08 & 0.03 \\
Model 11 & 2.80 & - & 0.01 & 0.05 & - & 0.45 & -10463.40 & 20939.4 & 4.19 & 0.03 \\
Model 12 & 2.40 & 0.16 & - & -0.07 & 0.02 & 0.42 & -10462.68 & 20940.2 & 4.97 & 0.02 \\
Model 13 & 2.38 & - & 0.01 & 0.06 & - & 0.43 & -10462.68 & 20940.2 & 4.98 & 0.02 \\
\hline
\end{tabular}

${ }^{\mathrm{a}}$ Variables were log-transformed. 

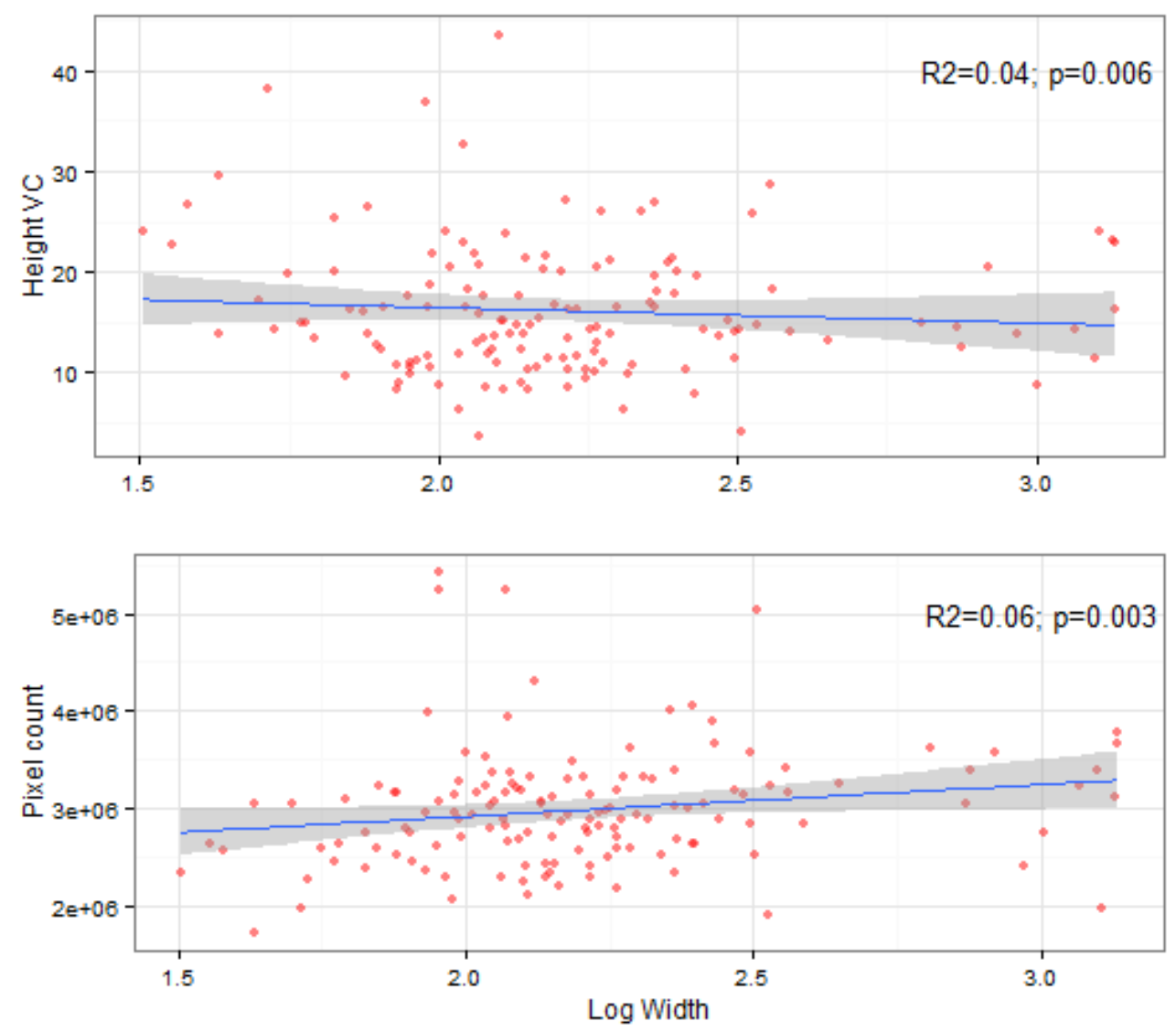

690

SM5. Relationship between the two vertical profile variables (height variation coefficient and total pixel count) and forest quality, measured as the proportion of closed-canopy forest.

695 


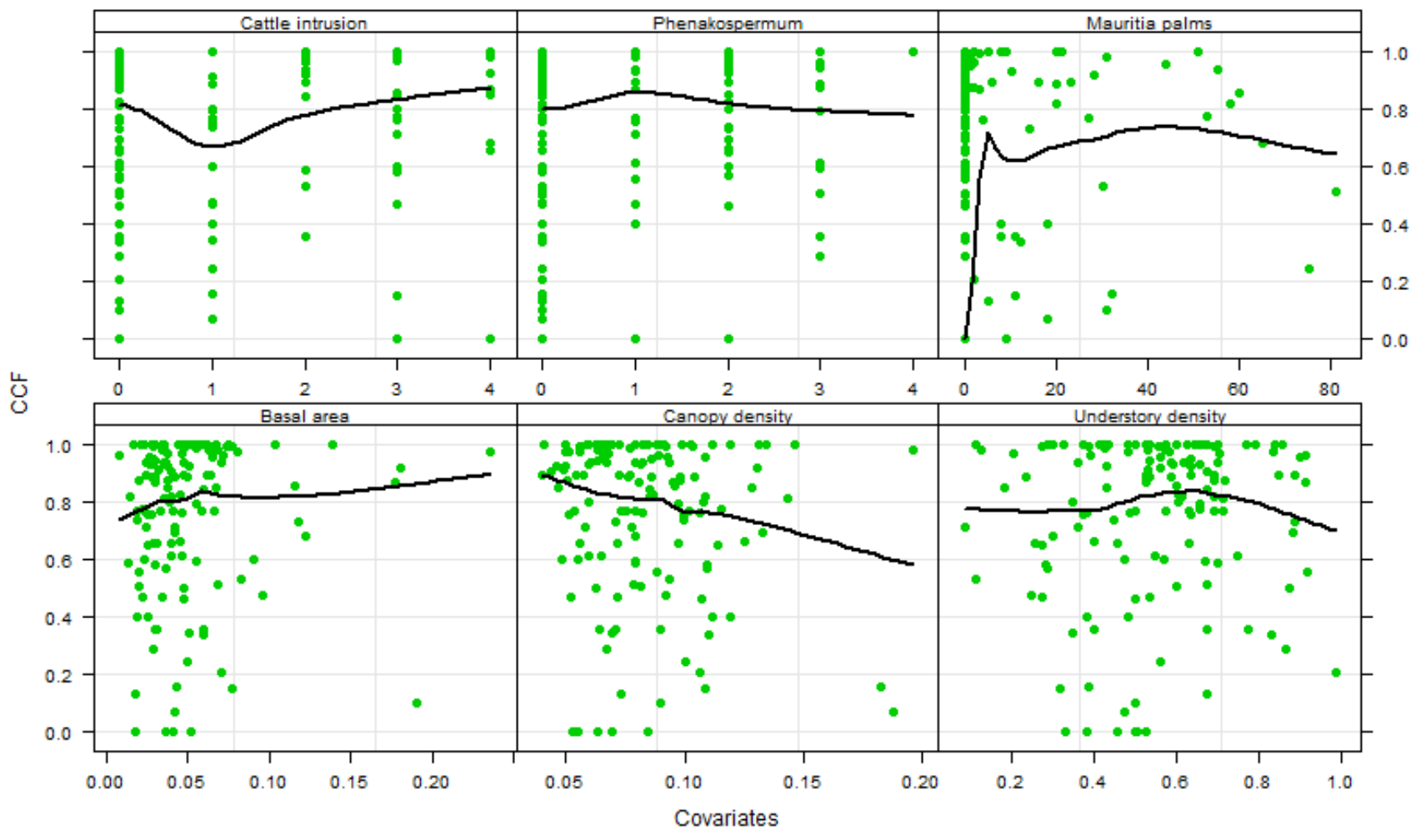

SM6. Relationship between forest structural variables obtained in situ and the proportion of closedcanopy forest obtained from the classification of 15-m resolution RapidEye images 


\section{Conclusões gerais}

O presente trabalho visou revisar e avaliar empiricamente o papel das áreas de preservação permanente (APPs), previstas no Código Florestal (Lei 12.651/2012), como potenciais corredores ecológicos locais para os mamíferos de médio e grande porte na Amazônia meridional. Além disso, como fechamento da tese, nós conduzimos um estudo sobre o atual estado de preservação de APPs ripárias e de nascentes na área de estudo. Como conclusões gerais do trabalho, podemos destacar:

- As áreas de floresta ripária remanescente na região apresentam o potencial de funcionar como conectores de paisagem para uma grande parte da fauna. No entanto, esse potencial depende de fatores associados aos remanescentes e à paisagem em que eles estão inseridos. Os principais fatores ambientais que influenciaram a comunidade de mamíferos foram: a largura dos corredores, o grau de isolamento destes na paisagem, e o grau de degradação dos remanescentes.

- As espécies analisadas responderam de forma diferente às características dos corredores. Principalmente as espécies estritamente florestais, menos adaptadas à ambientes abertos, são menos tolerantes à degradação e ao tamanho dos remanescentes, assim como ao isolamento do corredor. Essas espécies também responderam a fatores adicionais, como o grau de intrusão de gado no interior das florestas ripárias e a densidade de sub-bosque.

- A degradação florestal foi a variável mais influente nos padrões de comunidade e de ocupação de diferentes espécies. No entanto, é um fator negligenciado pela legislação ambiental, que permite que as APPs sejam mantidas em qualquer estado de preservação ou regeneração, permitindo até a exploração dessas áreas com a inclusão de espécies exóticas. Da mesma forma, na região, as veredas são uma das fisionomias mais desmatadas e degradadas, e a fauna de mamíferos respondeu negativamente à presença dessa fisionomia no interior dos corredores. A manutenção das florestas em melhor estado de preservação terá um efeito importante no uso dos remanescentes ripários pelas espécies de mamíferos terrestres. 
- A estrutura da paisagem afetou os padrões de ocupação de espécies sociais e estritamente florestais. Especificamente o isolamento do corredor ripário na paisagem e a largura dos remanescentes foram fatores que influenciaram essas espécies.

- As APPs ripárias e de nascente estão em geral em mau estado de preservação no município de Alta Floresta, mas as florestas das nascentes são em geral mais desmatadas e degradadas que as florestas ripárias. A quantidade e qualidade desses remanescentes estão associados principalmente ao tamanho da propriedade em que estão inseridos, à distância às estradas principais do municípios e à distância à cidade sede de Alta Floresta.

- Principalmente em pequenas propriedades, ações de incentivo à recuperação das áreas degradadas devem ser planejadas, e essa recuperação deve ter metas além dos requerimentos previstos na legislação, já que o novo Código Florestal anistiou grande parte do passivo ambiental dessas pequenas propriedades. Um apoio técnico e financeiro são alternativas para atingir esse objetivo e garantir o papel das matas ripárias como conectores de paisagem para a biodiversidade. 